NATIONAL TOXICOLOGY PROGRAM

Technical Report Series

No. 288

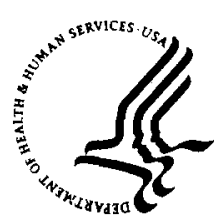

\title{
TOXICOLOGY AND CARCINOGENESIS
} STUDIES OF

1,3-BUTADIENE

(CAS NO. 106-99-0)

IN B6C3F 1 MICE

(INHALATION STUDIES)

U.S. DEPARTMENT OF HEALTH AND HUMAN SERVICES

Public Health Service

National Institutes of Health 


\section{NATIONAL TOXICOLOGY PROGRAM}

The National Toxicology Program (NTP), established in 1978, develops and evaluates scientific information about potentially toxic and hazardous chemicals. This knowledge can be used for protecting the health of the American peopie and for the primary prevention of disease. By bringing together the relevant programs, staff, and resources from the U.S. Public Health Service, DHHS, the National Toxicology Program has centralized and strengthened activities relating to toxicology research, testing and test development/validation efforts, and the dissemination of toxicological information to the public and scientific communities and to the research and regulatory agencies.

The NTP is made up of four charter DHHS agencies: the National Cancer Institute (NCI), National Institutes of Health; the National Institute of Environmental Health Sciences (NIEHS), National Institutes of Health; the National Center for Toxicological Research, Food and Drug Administration; and the National Institute for Occupational Safety and Health (NIOSH), Centers for Disease Control. In July 1981, the Carcinogenesis Bioassay Testing Program, NCI, was transferred to the NIEHS. 
NTP TECHNICAL REPORT

ON THE

\section{TOXICOLOGY AND CARCINOGENESIS}

STUDIES OF 1,3-BUTADIENE

(CAS NO. 106-99-0)

IN B6C3F 1 MICE

(INHALATION STUDIES)

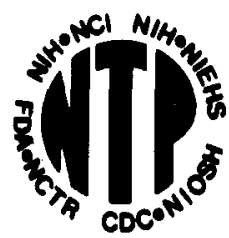

NATIONAL TOXICOLOGY PROGRAM

P.O. BoX 12233

Research Triangle Park, NC 27709

August 1984

NTP TR 288

NTP-83-071

NIH Publication No. 84-2544

U.S. DEPARTMENT OF HEALTH AND HUMAN SERVICES Public Health Service

National Institutes of Health 


\section{NOTE TO THE READER}

These studies are designed and conducted to characterize and evaluate the toxicologic potential, including carcinogenic activity, of selected chemicals in laboratory animals (usually two species, rats and mice). Chemicals selected for testing in the NTP Carcinogenesis Program are chosen primarily on the bases of human exposure, level of production, and chemical structure. Selection per se is not an indicator of a chemical's carcinogenic potential. Negative results, in which the test animals do not have a greater incidence of cancer than control animals, do not necessarily mean that a test chemical is not a carcinogen, inasmuch as the experiments are conducted under a limited set of conditions. Positive results demonstrate that a test chemical is carcinogenic for animals under the conditions of the test and indicate that exposure to the chemical has the potential for hazard to humans. The determination of the risk to humans from chemicals found to be carcinogenic in animals requires a wider analysis which extends beyond the purview of this study.

Five categories of interpretative conclusions were adopted in June 1983 for use in the Technical Reports series to specifically emphasize consistency and the concept of actual evidence of carcinogenicity. For each definitive study result (male rats, female rats, male mice, female mice), one of the following quintet will be selected to describe the findings. These categories refer to the strength of the experimental evidence and not to either potency or mechanism.

- Clear Evidence of Carcinogenicity is demonstrated by studies that are interpreted as showing a chemically related increased incidence of malignant neoplasms, studies that exhibit a substantially increased incidence of benign neoplasms, or studies that exhibit an increased incidence of a combination of malignant and benign neoplasms where each increases with dose.

- Some Evidence of Carcinogenicity is demonstrated by studies that are interpreted as showing a chemically related increased incidence of benign neoplasms, studies that exhibit marginal increases in neoplasms of several organs/tissues, or studies that exhibit a slight increase in uncommon malignant or benign neoplasms.

- Equivocal Evidence of Carcinogenicity is demonstrated by studies that are interpreted as showing a chemically related marginal increase of neoplasms.

- No Evidence of Carcinogenicity is demonstrated by studies that are interpreted as showing no chemically related increases in malignant or benign neoplasms.

- Inadequate Study of Carcinogenicity demonstrates that because of major qualitative or quantitative limitations, the studies cannot be interpreted as valid for showing either the presence or absence of a carcinogenic effect.

Additionally, the following concepts (as patterned from the International Agency for Research on Cancer Monographs) have been adopted by the NTP to give further clarification of these issues:

The term chemical carcinogenesis generally means the induction by chemicals of neoplasms not usually observed, the earlier induction by chemicals of neoplasms that are commonly observed, or the induction by chemicals of more neoplasms than are generally found. Different mechanisms may be involved in these situations. Etymologically, the term carcinogenesis means induction of cancer, that is, of malignant neoplasms; however, the commonly accepted meaning is the induction of various types of neoplasms or of a combination of malignant and benign neoplasms. In the Technical Reports, the words tumor and neoplasm are used interchangeably.

This study was initiated by the National Cancer Institute's Carcinogenesis Testing Program, now part of the National Institute of Environmental Health Sciences, National Toxicology Program. The study described in this Technical Report has been conducted under NTP health and safety requirements and/or guidelines for toxicity studies. Individual toxicology testing contractors are required to demonstrate corporate health and safety programs in compliance with NTP chemical health and safety requirements and to meet or exceed all applicable Federal, state, and local health and safety regulations.

Although every effort is made to prepare the Technical Reports as accurately as possible, mistakes may occur. Readers are requested to identify any mistakes so that corrective action may be taken. Further, anyone who is aware of related ongoing or published studies not mentioned in this report is encouraged to make this information known to the NTP. Comments and guestions about the National Toxicology Program Technical Reports on Toxicology and Carcinogenesis Studies should be directed to Dr. J.E. Huff, National Toxicology Program, P.O. Box 12233, Research Triangle Park, NC 27709 (919-541-3780).

These NTP Technical Reports are available for sale from the National Technical Information Service, U.S. Department of Commerce, 5285 Port Royal Road, Springfield, VA 22161 (703-487-4650). Single copies of this Technical Report are available without charge (and while supplies last) from the NTP Public Information Office, National Toxicology Program, P.O. Box 12233, Research Triangle Park, NC 27709. 


\section{CONTENTS}

ABSTRACT

.8

CONTRIBUTORS

10

PEER REVIEW PANEL $\ldots \ldots \ldots \ldots \ldots \ldots \ldots \ldots \ldots \ldots \ldots \ldots \ldots \ldots \ldots \ldots \ldots \ldots \ldots \ldots \ldots \ldots \ldots \ldots$

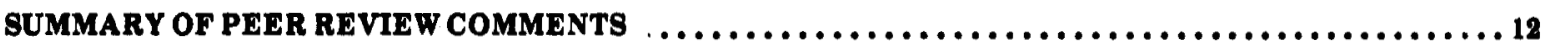

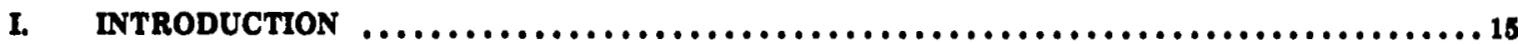

ANIMAL TOXICITY STUdIES $\ldots \ldots \ldots \ldots \ldots \ldots \ldots \ldots \ldots \ldots \ldots \ldots \ldots \ldots \ldots \ldots \ldots \ldots \ldots$

METABOLSM ...............................................17

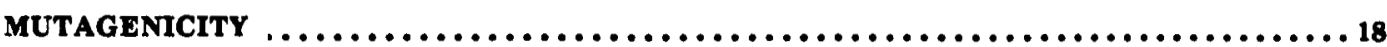

TERATOGENTCITY AND REPRODUCTIVE EFFECTS $\ldots \ldots \ldots \ldots \ldots \ldots \ldots \ldots \ldots \ldots \ldots$

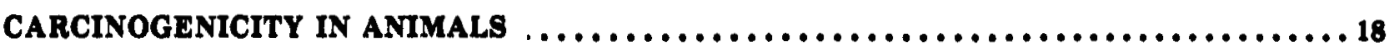

EFELCTS ON HUMANS $\ldots \ldots \ldots \ldots \ldots \ldots \ldots \ldots \ldots \ldots \ldots \ldots \ldots \ldots \ldots \ldots \ldots \ldots \ldots \ldots \ldots \ldots$

REASON FOR TESTING $\ldots \ldots \ldots \ldots \ldots \ldots \ldots \ldots \ldots \ldots \ldots \ldots \ldots \ldots \ldots \ldots \ldots \ldots \ldots \ldots \ldots \ldots \ldots \ldots$

I. MATERIALS AND METHODS $\ldots \ldots \ldots \ldots \ldots \ldots \ldots \ldots \ldots \ldots \ldots \ldots \ldots \ldots \ldots \ldots \ldots \ldots \ldots \ldots \ldots$

PROCUREMENT AND CHARACTERIZATION OF 1,3-BUTADIENE _..............22 GENERATION OF CHAMBER CONCENTRATIONS FOR THE SIXTY-ONE-WEEK

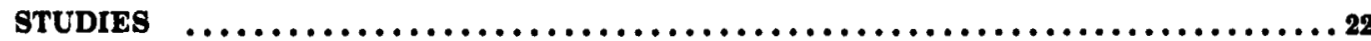

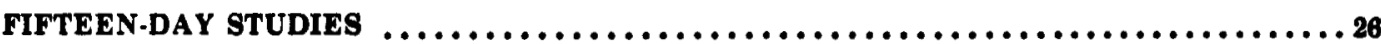

FOURTEEN-WEEK STUDIES $\ldots \ldots \ldots \ldots \ldots \ldots \ldots \ldots \ldots \ldots \ldots \ldots \ldots \ldots \ldots \ldots \ldots \ldots \ldots \ldots \ldots \ldots$

SIXTY-ONE-WEEK STUDIES $\ldots \ldots \ldots \ldots \ldots \ldots \ldots \ldots \ldots \ldots \ldots \ldots \ldots \ldots \ldots \ldots \ldots \ldots \ldots \ldots \ldots \ldots$

STUDY DESIGN . .......................................26

SOURCE AND SPECIFICATIONS OF TEST ANIMALS $\ldots \ldots \ldots \ldots \ldots \ldots \ldots \ldots \ldots$

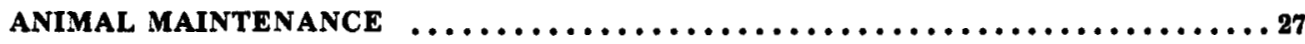

CLINICAL EXAMINATIONS AND PATHOLOGY $\ldots \ldots \ldots \ldots \ldots \ldots \ldots \ldots \ldots \ldots \ldots$

STATISTICAL METHOdS $\ldots \ldots \ldots \ldots \ldots \ldots \ldots \ldots \ldots \ldots \ldots \ldots \ldots \ldots \ldots \ldots \ldots \ldots$

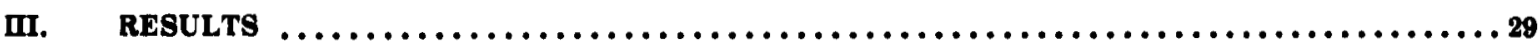

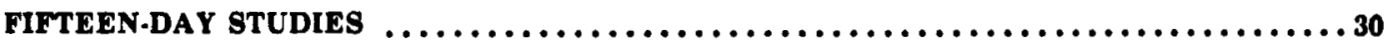

FOURTEEN.WEEK STUDIES $\ldots \ldots \ldots \ldots \ldots \ldots \ldots \ldots \ldots \ldots \ldots \ldots \ldots \ldots \ldots \ldots \ldots \ldots \ldots \ldots$

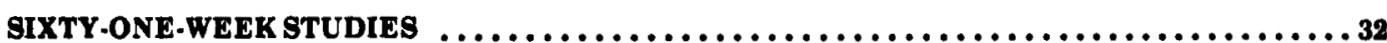

BODY WEIGHTS AND CLINICAL gIGNS $\ldots \ldots \ldots \ldots \ldots \ldots \ldots \ldots \ldots \ldots \ldots \ldots \ldots \ldots \ldots$

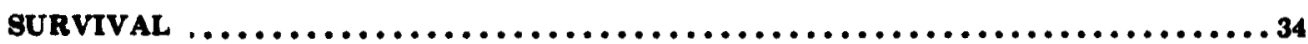

PATHOLOGY AND STATISTICAL ANALYSES OF RESULTS $\ldots \ldots \ldots \ldots \ldots \ldots$

IV. DISCUSSION AND CONCLUSIONS $\ldots \ldots \ldots \ldots \ldots \ldots \ldots \ldots \ldots \ldots \ldots \ldots \ldots \ldots \ldots \ldots \ldots \ldots \ldots \ldots$

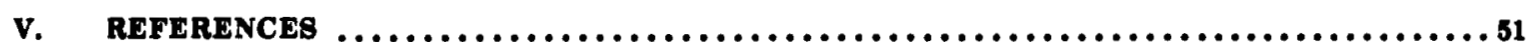




\section{TABLES}

TABLE 1 EXPERIMENTAL DESIGN AND MATERIALS AND METHODS IN THE INHALATION STUDIES OF 1,3 -BUTADIENE $\ldots \ldots \ldots \ldots \ldots \ldots \ldots \ldots \ldots \ldots \ldots \ldots \ldots \ldots \ldots \ldots \ldots \ldots \ldots$

TABLE 2 SURVIVAL AND MEAN BODY WEIGHTS OF MICE IN THE FIFTEEN-DAY INHALATION STUDIES OF 1,3-BUTADIENE

TABLE 3 SURVIVAL AND MEAN BODY WEIGHTS OF MICE IN THE FOURTEEN.WEEK INHALATTON STUDIES OF 1,3 -BUTADIENE $\ldots \ldots \ldots \ldots \ldots \ldots \ldots \ldots \ldots \ldots \ldots \ldots$

TABLE 4 MEAN BODY WEIGHTS AND SURVIVAL OF MICE IN THE SIXTY-ONE-WEEK INHALATION STUDIES OF 1,3 -BUTADIENE $\ldots \ldots \ldots \ldots \ldots \ldots \ldots \ldots \ldots \ldots \ldots \ldots$

TABLE 5 SURVIVAL OF MICE IN THE SIXTY-ONE-WEEK INHALATION STUDIES OF

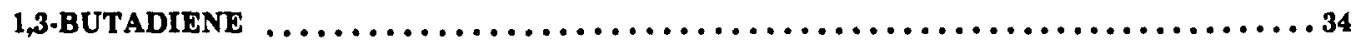

TABLE 6 ANALYSIS OF LUNG LESIONS IN MICE IN THE SIXTY-ONE-WEEK INHALATION

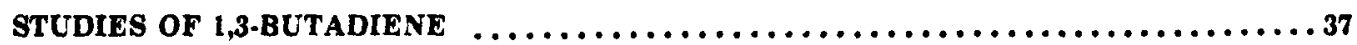

TABLE 7 ANALYSIS OF HEMATOPOIETIC SYSTEM TUMORS IN MICE IN THE SIXTY-ONEWEEK INHALATION STUDIES OF 1,3 -BUTADIENE $\ldots \ldots \ldots \ldots \ldots \ldots \ldots \ldots \ldots \ldots$

TABLE 8 ANALYSIS OF HEART LESIONS IN MICE IN THE SIXTY-ONE-WEEK INHALATION

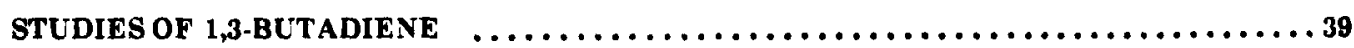

TABLE 9 ANALYSIS OF FORESTOMACH LESIONS IN MICE IN THE SIXTY.ONE.WEEK INHALATION STUDIES OF 1,3-BUTADIENE .40

TABLE 10 ANALYSIS OF LIVER TUMORS IN FEMALE MICE IN THE SIXTY-ONE-WEEK INHALATION STUDY OF 1,3 -BUTADIENE $\ldots \ldots \ldots \ldots \ldots \ldots \ldots \ldots \ldots \ldots \ldots \ldots \ldots \ldots$

TABLE 11 ANALYSIS OF MAMMARY GLAND LESIONS IN FEMALE MICE IN THE SIXTY.ONEWEEK INHALATION STUDY OF 1,3 -BUTADIENE $\ldots \ldots \ldots \ldots \ldots \ldots \ldots \ldots \ldots \ldots \ldots$

TABLE 12 NUMBERS OF FEMALE MICE WITH NEOPLASTIC AND NONNEOPLASTIC LESIONS IN THE OVARY IN THE SIXTY-ONE-WEEK INHALATION STUDY OF 1,3-BUTADIENE _..43

TABLE 13 ANALYSIS OF OVARIAN TUMORS IN FEMALE MICE IN THE SIXTY-ONE-WEEK INHALATION STUDY OF 1,3 -BUTADIENE $\ldots \ldots \ldots \ldots \ldots \ldots \ldots \ldots \ldots \ldots \ldots \ldots \ldots \ldots$

TABLE 14 NUMBERS OF MICE WITH NONNEOPLASTIC LESIONS OF THE NASAL CAVTTY IN THE SIXTY-ONE-WEEK INHALATION STUDIES OF 1,3 -BUTADIENE $\ldots \ldots \ldots \ldots \ldots 44$

TABLE 15 SIGNIFICANT EFFECTS OF EXPOSURE TO 1,3-BUTADIENE ON SPRAGUE. DAWLEY RATS AND B6C3F 1 MICE IN INHALATION BTUDIES .47 


\section{FIGURES}

PAGE

FTGURE 1 GROWTH CURVES FOR MICE EXPOSED TO 1,3-BUTADIENE BY INHALATION FOR SIXTY-ONE WEEKS .33

FIGURE 2 KAPLAN.MEIER SURVIVAL CURVES FOR MICE EXPOSED TO 1,3-BUTADIENE BY INHALATION FOR SIXTY-ONE WEEKS $\ldots \ldots \ldots \ldots \ldots \ldots \ldots \ldots \ldots \ldots \ldots \ldots \ldots \ldots, \ldots \ldots \ldots$

FIGURE 3 INFRARED ABSORPTION SPECTRUM OF 1,3 -BUTADIENE $\ldots \ldots \ldots \ldots \ldots \ldots \ldots$

FIGURE 4 SCHEMATIC DIAGRAM OF THE 1,3-BUTADIENE GAS DISTRIBUTION SYSTEM ...97

FIGURE 5 SCHEMATIC FRONT VIEW OF CHAMBER SHOWING APPROXIMATE SAMPLE

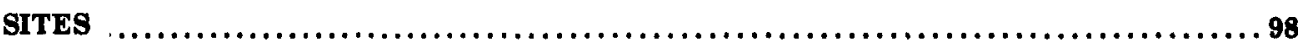

FIGURE 6 WEEKLY MEAN CONCENTRATION AND STANDARD DEVIATION IN 625-PPM MOUSE EXPOSURE CHAMBER FOR ENTIRE SIXTY-ONE-WEEK STUDIES $\ldots \ldots \ldots 100$

FIGURE 7 WEEKLY MEAN CONCENTRATION AND STANDARD DEVIATION IN 1,250-PPM MOUSE EXPOSURE CHAMBER FOR ENTIRE SIXTY.ONE.WEEK STUDIES $\ldots \ldots \ldots 101$ 
APPENDIX A SUMMARY OF THE INCIDENCE OF NEOPLASMS IN MICE IN THE SIXTY. ONE.WEEK INHALATION STUDIES OF 1,3 -BUTADIENE $\ldots \ldots \ldots \ldots \ldots \ldots$

TABLE A1 SUMMARY OF THE INCIDENCE OF NEOPLASMS IN MALE MICE IN THE SIXTY-ONE-WEEK INHALATION STUDY OF 1,3 -BUTADIENE $\ldots \ldots \ldots \ldots \ldots \ldots$

TABLE A2 SUMMARY OF THE INCIDENCE OF NEOPLASMS IN FEMALE MICE IN THE SIXTY-ONE-WEEK INHALATION STUDY OF 1,3 -BUTADIENE $\ldots \ldots \ldots \ldots \ldots \ldots$

TABLE A3 INDIVIdUAL ANIMAL TUMOR PATHOLOGY OF MALE MICE IN THE SIXTY. ONE-WEEK INHALATION STUDY OF $1,3 \cdot$ BUTADIENE $\ldots \ldots \ldots \ldots \ldots \ldots \ldots$

TABLE A4 INDIVIDUAL ANIMAL TUMOR PATHOLOGY OF FEMALE MICE IN THE SIXTY-ONE-WEEK INHALATION STUDY OF 1,3 -BUTADIENE $\ldots \ldots \ldots \ldots \ldots$

APPENDIX B SUMMARY OF THE INCIDENCE OF NONNEOPLASTIC LESIONS IN MICE IN THE SIXTY.ONE.WEEK INHALATION STUDIES OF 1,3 -BUTADIENE $\ldots \ldots \ldots \ldots 7$

TABLE B1 SUMMARY OF THE INCIDENCE OF NONNEOPLASTIC LESIONS IN MALE MICE IN THE SIXTY.ONE-WEEK INHALATION STUDY OF $1,3-$ BUTADIENE $\ldots \ldots \ldots \ldots \ldots 78$

TABLE B2 SUMMARY OF THE INCIDENCE OF NONNEOPLASTIC LESIONS IN FEMALE MICE IN THE SIXTY.ONE-WEEK INHALATION STUDY OF 1,3 -BUTADIENE $\ldots \ldots 81$

APPENDIX C ANALYSES OF PRIMARY TUMORS IN MICE IN THE SIXTY-ONE-WEEK INHALATION STUDKES OF 1,3-BUTADIENE .85

TABLE C1 ANALYSIS OF PRIMARY TUMORS IN MALE MICE IN THE SIXTY-ONE-WEEK INHALATION STUDY OF 1,3 -BUTADIENE $\ldots \ldots \ldots \ldots \ldots \ldots \ldots \ldots \ldots \ldots \ldots \ldots$

TABLE C2 ANALYSIS OF PRIMARY TUMORS IN FEMALE MICE IN THE SIXTY-ONE-WEEK STUDY OF 1,3 -BUTADIENE $\ldots \ldots \ldots \ldots \ldots \ldots \ldots \ldots \ldots \ldots \ldots \ldots \ldots \ldots \ldots \ldots \ldots \ldots \ldots$

APPENDIX D CHEMICAL CHARACTERIZATION OF 1,3-BUTADLENE $\ldots \ldots \ldots \ldots \ldots \ldots \ldots \ldots$

TABLE D1 SUMMARY OF PURITY OF 1,3-BUTADIENE IN THE SIXTY-ONE-WEEK

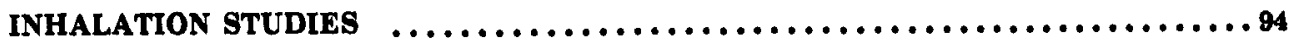

APPENDIX E GENERATION AND MONITORING OF CHAMBER CONCENTRATIONS ........95

TABLE E1 1,3-BUTADIENE VAPOR CONCENTRATION UNIFORMTTY TEST $\ldots \ldots \ldots \ldots \ldots \ldots \ldots$ 


\begin{abstract}
APPENDIXES (CONTINUED)
PAGE

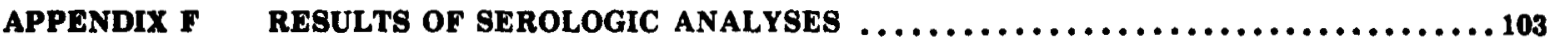

TABLE F1 MURINE VIRUS ANTIBODY DETERMINATIONS IN MICE IN THE SIXTY.

ONE-WEEK INHALATION STUDIES OF 1,3 -BUTADIENE $\ldots \ldots \ldots \ldots \ldots \ldots \ldots \ldots 1$

APPENDIX G INGREDIENTS, NUTRIENT COMPOSITION, AND MEASURED CONTAMINANT

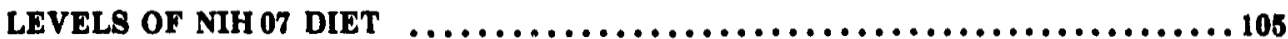

TABLE G1 INGREDIENTS OF NIH 07 RAT AND MOUSE DIET $\ldots \ldots \ldots \ldots \ldots \ldots \ldots \ldots \ldots$

TABLE G8 VITAMINS AND MINERALS IN THE NIH 07 DIET $\ldots \ldots \ldots \ldots \ldots \ldots \ldots \ldots \ldots, \ldots$

TABLE G3 NUTRIENT COMPOSITION OF NIH 07 DIET: PELLETS $\ldots \ldots \ldots \ldots \ldots \ldots \ldots \ldots 107$

TABLE G4 CONTAMINANT LEVELS OF NIH 07 DIET: PELLETS $\ldots \ldots \ldots \ldots \ldots \ldots \ldots \ldots$

APPENDIX H EXPERIMENTAL DATA AUDIT OF THE SIXTY-ONE-WEEK INHALATION STUDIES OF 1,3 -BUTADIENE $\ldots \ldots \ldots \ldots \ldots \ldots \ldots \ldots \ldots \ldots \ldots \ldots \ldots \ldots \ldots \ldots$
\end{abstract}




\title{
$\mathrm{CH}_{2}=\mathrm{CH} \cdot \mathrm{CH}=\mathrm{CH}_{2}$
}

\section{1,3-BUTADIENE}

CAS NO. 106-99-0

\author{
$\mathrm{C}_{4} \mathrm{H}_{6} \quad$ Mol. Wt. 54.09
}

Synonyms: butadiene, biethylene, bivinyl, divinyl, erythrene, vinylethylene, pyrrolylene

\begin{abstract}
Male and female $\mathrm{B}_{6 \mathrm{C}} 3 \mathrm{~F}_{1}$ mice were exposed to air containing 1,3-butadiene (greater than 99\% pure) at concentrations of $0-8,000 \mathrm{ppm}$ in 15-day and 14-week inhalation studies. In the 15-day studies, survival was unaffected by dose, and no pathologic effects were observed; slight decreases in mean body weight occurred at the high concentrations. In the 14-week studies, mean body weight gain decreased with dose, and survival in the 5,000-ppm and 8,000-ppm groups of males was markedly reduced; no other compound-related effects were reported.

Inhalation carcinogenesis studies of 1,3-butadiene were conducted by exposing groups of 50 male and female $\mathrm{B}_{6} \mathrm{C}_{3} \mathrm{~F}_{1}$ mice 6 hours per day for 5 days per week to air containing the test chemical at concentrations of 0 (chamber controls), 625 , or $1,250 \mathrm{ppm}$. These studies were planned for 103-week exposures but were terminated at week 60 for male mice and week 61 for female mice because of the rapidly declining survival, primarily due to neoplasia. Body weights were not affected by 1,3butadiene.

Significantly increased incidences of neoplasms at multiple sites were observed in mice exposed to 1,3-butadiene. Hemangiosarcomas of the heart occurred at increased incidences in exposed males and females (male: control, $0 / 50$; low dose, 16/49; high dose, 7/49; female: $0 / 50 ; 11 / 48 ; 18 / 49$ ). Hemangiosarcomas were also observed in the peritoneal cavity (one high dose male), subcutaneous tissue (two low dose females), and liver (one high dose female).
\end{abstract}

Malignant lymphomas, diagnosed as early as week 20 , were observed at increased incidences in exposed male and female mice (male: $0 / 50 ; 23 / 50 ; 29 / 50$; female: $1 / 50 ; 10 / 49 ; 10 / 49$ ).

Alveolar/bronchiolar adenomas and alveolar/bronchiolar carcinomas (both separately and combined) occurred at increased incidences in exposed male and female mice (combined incidences--male: 2/50; $14 / 49 ; 15 / 49$; female: $3 / 49 ; 12 / 48 ; 23 / 49$ ).

Epithelial hyperplasia of the forestomach occurred at increased incidences in dosed mice (male: $0 / 49$; $5 / 40 ; 7 / 44$; female: $0 / 49 ; 5 / 42 ; 9 / 49$ ). Papillomas of the forestomach occurred in low dose male and in low dose and high dose female mice (male: $0 / 49 ; 5 / 40 ; 0 / 44$; female: $0 / 49 ; 4 / 42 ; 10 / 49$ ). Squamous cell carcinomas of the forestomach were observed in dosed mice (male: $0 / 49,2 / 40,1 / 44$; female: $0 / 49,1 / 42$, 1/49).

Acinar cell carcinomas of the mammary gland were observed at an increased incidence in high dose female mice $(0 / 50 ; 2 / 49 ; 6 / 49)$; adenosquamous carcinomas were found in four low dose females. The 
incidences of granulosa cell tumors of the ovary were increased in dosed females $(0 / 49 ; 6 / 45 ; 12 / 48)$. A granulosa cell carcinoma was observed in another high dose female. Gliomas were observed in two 68- to 69-week-old low dose and one high dose male mice; brain tumors are uncommon even in 2-yearold mice.

Liver necrosis occurred at increased incidences in dosed male and low dose female mice (male: $1 / 50$, $8 / 49,8 / 49$; female: 6/50, 15/47,6/49). Hepatocellular adenomas or carcinomas (combined) were observed at an increased incidence in high dose female mice $(0 / 50,2 / 47,5 / 49)$.

No neoplastic lesions of the nasal cavity were observed at any dose level. The following nonneoplastic lesions of the nasal cavity occurred in mice exposed at 1,250 ppm: chronic inflammation (male, 35/50; female, 2/49); fibrosis (male, 35/50; female, 2/49); cartilaginous metaplasia (male, 16/50; female, 1/49); osseous metaplasia (male, 11/50; female, 2/49); and atrophy of the sensory epithelium (male, $32 / 50$ ). No nonneoplastic lesions of the nasal cavity were found in the controls. The incidence of testicular atrophy $(0 / 50,19 / 49,11 / 48)$ or ovarian atrophy $(2 / 49,40 / 45,40 / 48)$ was increased in exposed male or female mice.

An audit of the experimental data from these studies on 1,3-butadiene was conducted by the National Toxicology Prngram. No data discrepancies were found that influenced the final interpretation of these experiments.

Under the conditions of these studies, there was clear evidence of carcinogenicity* for 1,3-butadiene in male and female $\mathrm{B} 6 \mathrm{C} 3 \mathrm{~F}_{1}$ mice, as shown by increased incidences and early induction of hemangiosarcomas of the heart, malignant lymphomas, alveolar/bronchiolar adenomas and carcinomas, and papillomas of the stomach in males and females; and of acinar cell carcinomas of the mammary gland, granulosa cell tumors of the ovary, and hepatocellular adenomas and adenomas or carcinomas (combined) in females. 1,3-Butadiene was associated with nonneoplastic lesions in the respiratory epithelium, liver necrosis, and testicular or ovarian atrophy.

*Categories of evidence of carcinogenicity are defined in the Note to the Reader on page 2. 


\title{
CONTRIBUTORS
}

The NTP Technical Report on the Toxicology and Carcinogenesis Studies of 1,3-Butadiene is based on the 14-week studies that began in May 1977 and ended in September 1977 at Industrial Biotest Laboratories and on the 61-week studies that began in April 1981 and ended in June 1982 at Battelle Pacific Northwest Laboratories.

\author{
National Toxicology Program \\ P.O. Box 12233 \\ Research Triangle Park, NC 27709 \\ (Evaluated Experiment, Interpreted Results, and Reported Findings) \\ Marcelina Powers, D.V.M.,Chemical Manager
}

Gary A. Boorman, D.V.M., Ph.D.

Rajendra S. Chhabra, Ph.D.

David M. DeMarini, Ph.D.

Joseph K. Haseman, Ph.D.

James Huff, Ph.D.

C.W. Jameson, Ph.D.
E.E. McConnell, D.V.M

John A. Moore, D.V.M.

G. Rao, D.V.M., Ph.D.

B. A. Schwetz, D.V.M., Ph.D.

Raymond W. Tennant, Ph.D.

NTP Pathology Working Group

(Evaluated Slides and Prepared Pathology Report on 4/4/83)

$$
\text { Henk Solleveld, D.V.M., Ph.D., NTP (Chairman) }
$$

Gary A. Boorman, D.V.M., Ph.D.

NTP

Scot L. Eustis, D.V.M., Ph.D.

NTP

Marilyn Wolfe, D.V.M., Ph.D.

NTP
Kenneth Ayres, D.V.M.

Burroughs Wellcome

Kevin Morgan, Ph.D.

Chemical Industry Institute of Toxicology

\section{Principal Contributors at Battelle Pacific Northwest Laboratories}

(Conducted Studies and Evaluated Tissues)

William J. Clarke, D.V.M., Ph.D.

Principal Investigator

Rodney Miller, D.V.M., Ph.D.

Pathologist
R.B. Westerberg, Ph.D.

Chemist

\section{Principal Contributors at Experimental Pathology Laboratory (Provided Pathology Quality Assurance)}

Deborah A. Banas, D.V.M.

\section{Principal Contributors at Carltech Associates, Inc. \\ (Contractor for Technical Report Preparation)}

William D. Theriault, Ph.D.

Project Manager

Abigail C. Jacobs, Ph.D.

Senior Scientist
John Warner, M.S.

Chemist/Statistician 


\section{PEER REVIEW PANEL}

The members of the Peer Review Panel who evaluated this Technical Report are listed below. Panel members serve as independent scientists, not as representatives of any institution, company, or governmental agency. In this capacity, Panel members have five major responsibilities: (a) to ascertain that all relevant literature data have been adequately cited and interpreted, (b) to determine if the design and conditions of the NTP studies were appropriate, (c) to ensure that the Technical Report presents the experimental results and conclusions fully and clearly, (d) to judge the significance of the experimental results by scientific criteria, and (e) to assess the evaluation of the evidence of carcinogenicity and other observed toxic responses.

\section{National Toxicology Program Board of Scientific Counselors Technical Reports Review Subcommittee}

Jerry B. Hook, Ph. D. (Chairperson)

Vice President, Preclinical Research and Development

Smith Kline \& French Laboratories

Philadelphia, Pennsylvania

Curtis Harper, Ph.D. (Principal Reviewer)

Associate Professor of Pharmacology

School of Medicine

University of North Carolina

Chapel Hill, North Carolina
James Swenberg, Ph.D., D.V.M.

Chief of Pathology

Chemical Industry Institute of Toxicology

Research Triangle Park, North Carolina

\section{Ad Hoc Subcommittee Panel of Experts}

Louis S. Beliczky, M.S., M.P.H. (Principal Reviewer) Director, Department of Industrial Hygiene United Rubber Workers International Union Akron, Ohio

Devra L. Davis, Ph.D.

Science Policy Director

Environmental Law Institute

Washington, D.C.

Robert M. Elashoff, Ph.D

University of California at Los Angeles Jonsson Comprehensive Cancer Center Los Angeles, California

Seymour L. Friess, Ph.D. (Principal Reviewer) Arlington Virginia

J. Michael Holland, Ph.D., D.V.M. Chevron Environmental Health Center Richmond, California

Robert A. Scala, Ph.D. Exxon Corporation East Millstone, New Jersey
Tom Slaga, Ph.D.*

University of Texas System Cancer Center Science Park, Research Division Smithville, Texas

John R. Van Ryzin, Ph.D. (Principal Reviewer) Division of Biostatistics School of Public Health Columbia University New York, New York

Stan D. Vesselinovitch, Ph.D.* Professor, Departments of Radiology and Pathology University of Chicago Chicago, Illinois

Mary Vore, Ph.D.* Assistant Professor

Pharmacology Department

College of Medicine

University of Kentucky

Lexington, Kentucky

- Unable to attend October 28, 1983, meeting 


\section{SUMMARY OF PEER REVIEW COMMENTS ON THE TOXICOLOGY AND CARCINOGENESIS STUDIES OF 1,3-BUTADIENE}

On October 28, 1983, the technical report on 1,3-butadiene received peer review by the National Toxicology Program Board of Scientific Counselors' Technical Reports Review Subcommittee and associated Panel of Experts. The review meeting began at 9:00 a.m. in the Conference Center, Building 101, South Campus, National Institute of Environmental Health Sciences, Research Triangle Park, North Carolina.

Dr. J. Van Ryzin, a principal reviewer for the technical report on the carcinogenesis studies of 1,3butadiene, agreed with the conclusions given in the technical report. He said a statement in the abstract should emphasize that this inhalation study was designed for 103-104 weeks' exposure but was terminated at 60 and 61 weeks because of low survival concomitant with neoplasms.

As a second principal reviewer, Mr. L. Beliczky agreed with the conclusions. He suggested that an immunotoxicology profile on butadiene might be worthwhile, given the potential carcinogenicity of the chemical in the Zymbal gland. Also, in view of limited epidemiologic evidence associating employment in certain industries with occurrence of brain tumors, he suggested that more studies to evaluate the significance of the gliomas in male mice would be useful. He also noted that the reported hemangiosarcomas of the heart are an unusual neoplastic response. Dr. J. Swenberg supported the need for highlighting the occurrence of gliomas in view of their rarity in mice. Mr. Beliczky recommended comparative pharmacokinetic studies in Sprague-Dawley rats and $\mathrm{B} \mathrm{C}_{3} \mathrm{~F}_{1}$ mice because of apparent differences in sensitivity to tumor induction by 1,3-butadiene in the two species. $\mathrm{Dr}$. M. Powers, NTP, responded that such pharmacokinetic studies were being designed.

As a third principal reviewer, Dr. S. Friess agreed with the major conclusions as to "clear evidence of carcinogenicity." However, he suggested that the strength of evidence for papillomas and carcinomas of the forestomach in male and female mice better fits in the category of "some evidence of carcinogenicity," based on lack of dose response: in both sexes the incidences in the low dose groups were greater than those in the high dose groups. Dr. Friess also suggested adding liver adenomas and adenomas and carcinomas (combined) in females to the conclusions under the category of "clear evidence" because the dose trends and enhanced incidence rates at the high dose were clear and significant. Dr. J. Huff, NTP, indicated that a single category of evidence was generally selected for each sex and species and reflected the highest degree of evidence. In the discussion that followed, several Panel members concurred with this concept. [A statement has been added to the conclusions concerning the increased incidence of liver lesions in mice.] Dr. Friess also noted the increased incidence of nasal lesions in males, with no increase in neoplasia and the almost complete lack of such lesions in females.

As a fourth principal reviewer, Dr. C. Harper also agreed with the conclusions. He asked for clarification regarding the major cause of early deaths; in one section malignant lymphomas were stated as causative and elsewhere a number of deaths were attributed to hemangiosarcomas. Dr. G. Boorman, NTP, replied that the lymphomas occurred principally in the thymus and likely caused the animals to suffocate, while in some cases the heart lesions were contributory.

In other discussion, Dr. R. Scala noted that 1,3-butadiene is highly explosive and the concentrations used in the 13-week studies seemed near the explosive level. He emphasized the importance of listing the safety procedures used at the contract laboratory [see p. 96] and expressed concern that other inhalation studies with potent chemicals such as ethylene oxide and 1,2-epoxybutane were conducted in the same chamber room. Dr. E. McConnell, NTP, agreed and said that conducting several inhalation studies in the same chamber room would not be done routinely. He mentioned that the chambers 
used for each chemical were essentially closed systems and cross-contamination was unlikely. Dr. Scala stated that there was apparent inadequate randomization of the animals by weight. Dr. J. Haseman, NIEHS, agreed and said analysis showed that the initial weights in both sexes were significantly lower in the control groups than in the dosed groups [see p. 32]. Dr. Swenberg commented that although results were given for the 14-week studies, no pathology information was given; he requested that pathology findings or lack thereof be included in the report. [None was reported; see p. 31.]

In response to questions about the long-term inhalation study in Sprague-Dawley rats performed at Hazleton Laboratories, Europe, under the sponsorship of the International Institute of Synthetic Rubber Producers, Dr. Scala noted that the overall report had not been published but the findings of the 2-year carcinogenicity study would be submitted to a toxicology journal. Dr. B. Schwetz, NTP, stated that these data had been made available to the NTP and that an ongoing correspondence had been initiated.

Dr. Van Ryzin moved that the technical report on the carcinogenesis studies of 1,3-butadiene be accepted with the modifications discussed. To the conclusions would be added "hepatocellular adenomas and adenomas or carcinomas (combined)" in female mice. Dr. J. Holland seconded the motion and the technical report was approved by seven affirmative votes with two abstentions (Dr. Holland and Dr. Scala). 


\section{INTRODUCTION}

ANIMAL TOXICITY STUDIES

METABOLISM

MUTAGENICITY

TERATOGENICITY AND REPRODUCTIVE EFFECTS

CARCINOGENICITY IN ANIMALS

EFFECTS ON HUMANS

REASON FOR TESTING 


\title{
$\mathrm{CH}_{2}=\mathrm{CH}-\mathrm{CH}=\mathrm{CH}_{2}$
}

\section{1,3-BUTADIENE}

CAS NO. 106-99-0

\author{
$\mathrm{C}_{4} \mathrm{H}_{6}$ \\ Mol. Wt. 54.09
}

Synonyms: butadiene, biethylene, bivinyl, divinyl, erythrene, vinylethylene, pyrrolylene

1,3-Butadiene is a colorless gas produced commercially as an ethylene coproduct (about $60 \%$ of U.S. production), by oxidative dehydrogenation of $n$-butenes (about $25 \%$ of U.S. production), and by dehydrogenation of $n$-butane (about $15 \%$ of U.S. production) (SRI, 1980). Between 2.1 and 7.3 billion pounds of 1,3-butadiene were produced or imported in 1977 (USEPA, 1981). 1,3-Butadiene ranked 36 th in U.S. production ( 2.31 billion pounds) in 1983 (Chem. \& Eng. News, 1984). During the previous year, 1.38 billion pounds of 1,3-butadiene-derived thermoplastic resins and 1.33 million metric tons of synthetic rubber were produced (Chem. \&. Eng. News, 1983).

1,3-Butadiene is used as an intermediate in the production of elastomers, polymers, and other chemicals. Of the 1,3-butadiene used in 1978, $44 \%$ was used to manufacture styrene-butadiene rubber (a substitute for natural rubber, produced by copolymerization of 1,3-butadiene with styrene), and $19 \%$ was used to produce polybutane elastomer (a substance that increases resistance of tire products to wear, heat degradation, and blowouts). Chloroprene monomer, derived from 1,3-butadiene, is used exclusively to manufacture neoprene elastomers for non-tire and latex applications. Commercial nitrile rubber, used largely in rubber hoses, seals, and gaskets for automobiles, is a copolymer of 1,3butadiene and acrylonitrile. Acrylonitrile-butadiene-styrene resins, usually containing 20\%$30 \%$ 1,3-butadiene by weight, are used to make parts for automobiles and appliances. Other polymer uses include specialty polybutadiene polymers, thermoplastic elastomers, nitrile barrier resins, and $\mathrm{K}$ resins ${ }^{\oplus}$. 1,3-Butadiene is used as an intermediate in the production of a variety of industrial chemicals, including two fungicides, captan and captofol (USEPA, 1981). It is approved by the U.S. Food and Drug Administration for use in the production of adhesives used in articles for packaging, transporting, or holding food; in components of paper and paperboard that are in contact with dry food; and as a modifier in the production of semirigid and rigid vinyl chloride plastic food-contact articles (USCFR, 1978, rev. 1983). No information was located on the levels of monomer or on its elution rate from any of the commercially available polymers. It is not known if unreacted 1,3-butadiene migrates from packaging materials.

1,3-Butadiene has been detected in drinking water in the United States (Kraybill, 1980; USEPA, 1978); however, it is primarily an air contaminant. 1,3-Butadiene reacts photochemically in the atmosphere to generate smog; acrolein and formaldehyde are apparent byproducts (Parsons and Wilkins, 1976). It has been detected in cigarette smoke (Osborne et al., 1956), gasoline vapor (Stephens and Burleson, 1967), incineration products of fossil fuels (Natusch, 1978), and automobile exhaust (Neligan, 1962). 1,3-Butadiene has been detected in urban atmospheres in the United States at concentrations that generally range from 1 to $5 \mathrm{ppb}$ (Natusch, 1978). Concentrations of 0-19 ppb have been measured at industrial sites near Houston, TX (Siddiqi and Worley, 1977); a level of $30 \mathrm{ppb}$ was detected at another industrial area (Stephens, 1973). Concentrations of 40-45 ppm in 1960 and $2-10 \mathrm{ppm}$ in 1970 were reported in air samples and factory emissions at USSR petrochemical plants 
(Batkina, 1976; D'Yachkov, 1972; Faustov, 1972; Cyashenko and Sidenko, 1976).

Occupational exposure to 1,3-butadiene occurs mainly through inhalation and, to a lesser extent, by dermal contact. Approximately 62,000 U.S. workers are exposed annually (NIOSH, 1980). Most exposures occur in plants manufacturing the chemical or using it to produce polymers or elastomers. The international occupational exposure limits, expressed as timeweighted averages (TWA's), are: $1,000 \mathrm{ppm}$ in the United States, United Kingdom, Finland, West Germany, the Netherlands, Australia, Belgium, and Switzerland; $682 \mathrm{ppm}$ in Rumania; $454 \mathrm{ppm}$ in Italy; $223 \mathrm{ppm}$ in East Germany, Yugoslavia, and Czechoslovakia; and $45 \mathrm{ppm}$ in the Union of Soviet Socialist Republics, Bulgaria, and Poland (International Labor Office, 1977; ACGIH, 1981).

\section{ANIMAL TOXICITY STUDIES}

The median $\mathrm{LC}_{50}$ value of 1,3-butadiene in short-term inhalation studies was reported to be $117,700 \mathrm{ppm}$ for mice during an unspecified exposure period (Shugaev, 1969) and $122,700 \mathrm{ppm}$ for a 2-hour exposure period (Zlobina and Dueva, 1974). In rats, the $L_{50}$ value for a 4 -hour exposure was $129,500 \mathrm{ppm}$ (Shugaev, 1969). Short-term oral $L D_{50}$ values of $5.48 \mathrm{~g} / \mathrm{kg}$ for rats and $3.21 \mathrm{~g} / \mathrm{kg}$ for mice have been reported (Ripp, 1968). Rats exposed to 1,3-butadiene for 8 months at concentrations ranging from 600 to $6,700 \mathrm{ppm}$ ( 7.5 hours/day, 6 days/week) showed no adverse effects except for slight growth retardation at the highest concentration (Carpenter et al., 1944). Rabbits and rats exposed at a concentration of $4.5 \mathrm{ppm}$ for 4 hours per day for 4 months showed no effects; changes in the nervous system function occurred at $45 \mathrm{ppm}$ and $1,000 \mathrm{ppm}$. Changes in liver, kidney, and spleen morphology, the central nervous system, and immunologic status have been observed in rats exposed for 81 days at $0.45 \mathrm{ppm}$; morphologic changes in the nasopharynx occurred at 1.35 ppm; and hemodynamic changes, increased permeability of the vessels, and alteration of the structure of the kidney and heart were seen at $13.5 \mathrm{ppm}$ (Nikiforova et al., 1969; Crouch et al., 1979). Guinea pigs exposed briefly at 4.5-6.8 ppm had allergic reactions (Zlobina and Dueva, 1974).
Rats exposed to 1,3-butadiene at concentrations of 1,000-8,000 ppm for 6 hours per day, 5 days per week for 3 months showed moderately in. creased salivation at the higher concentrations; no effects on survival, growth rate, food consumption, hematologic and biochemical parameters, or gross or microscopic pathologic findings were observed (Crouch et al., 1979).

\section{METABOLISM}

The metabolism of 1,3-butadiene has not been studied extensively. Nine minutes after rabbits were exposed to 1,3-butadiene at concentrations of $250,000 \mathrm{ppm}$, the test chemical was found in the femoral artery at a concentration of 0.26 $\mathrm{mg} / \mathrm{ml}$ and in the femoral vein at $0.18 \mathrm{mg} / \mathrm{ml}$ (Carpenter et al., 1944). Concentrations of 1,3butadiene were determined in major organs of cats, rats, and mice exposed at or near the $\mathrm{LC}_{50}$ values for 1-4 hours (Shugaev, 1969). Rats (strain and sex unspecified) exposed to 1,3butadiene for 2 hours at concentrations of $130,000 \mathrm{ppm}$ had the test chemical at a high concentration in the perirenal fat $(152 \mathrm{mg} / 100 \mathrm{~g})$ and lower concentrations in the liver $(5 \mathrm{lmg} / 100 \mathrm{~g})$, brain $(50 \mathrm{mg} / 100 \mathrm{~g})$, spleen $(45 \mathrm{mg} / 100 \mathrm{~g})$, and kidney $(36 \mathrm{mg} / 100 \mathrm{~g})$. After rats were exposed at $130,000 \mathrm{ppm}$ for up to 1 hour, 1,3-butadiene concentrations in the brain and liver were similar $(34.6 \mathrm{mg} / 100 \mathrm{~g}$ and $33.6 \mathrm{mg} / 100 \mathrm{~g}$, respectively) immediately. after exposure, $2.9 \mathrm{mg} / 100 \mathrm{~g}$ and $3.3 \mathrm{mg} / 100 \mathrm{~g}$ 60 minutes after exposure, and 0 and trace amounts 90 minutes after exposure (Shugaev, 1969).

In vitro studies have shown that 1,3 -butadiene is converted to 1,2-epoxybutene by cytochrome $\mathrm{P}-450$ dependent mixed-function oxidases in rat liver microsomes (Malvoisin et al, 1979). Pretreatment with phenobarbital increased the 1,3-butadiene epoxydase activity. Incubation of the epoxide with rat liver microsomes and a NADPH-generating system produced four products: an unidentified metabolite, two metabolites resembling DL-1,2:3,4-diepoxybutane, and 3,4-epoxy-1,2-butane diol (Malvoisin and Roberfroid, 1982; Malvoisin et al., 1980). Pretreatment of rats with phenobarbital apparently enhanced the formation of the diol up to fifteenfold. The authors suggested that biotransformation of 3,4-epoxy-1-butene to 
3,4-epoxy-1,2-butane diol is mediated by a $\mathrm{mi}$ crosomal epoxide hydrase and by mixed function oxidases. These pathways have not been confirmed by in vivo studies.

\section{MUTAGENICITY}

All reported studies on the mutagenicity of 1,3butadiene used Salmonella typhimurium TA1530, a base-pair substitution strain. 1,3Butadiene was not found to be mutagenic when tested by the usual plate-incorporation protocol or by the preincubation protocol in the presence or absence of $\mathrm{S9}$ prepared from the livers of Aroclor-treated male Wistar rats (Poncelet et al., 1980). When bacterial cells and $S 9$ were incorporated into an agar overlay and exposed to gaseous 1,3-butadiene in a desiccator, the compound was mutagenic. Using the same protocol for gaseous 1,3-butadiene, de Meester et al. (1980) confirmed the findings of Poncelet et al. (1980) and showed that 1,3-butadiene was not mutagenic at atmospheric concentrations of $2 \%$ $35 \%(\mathrm{v} / \mathrm{v})$ in the absence of S9. When Petri plates containing only cells (no S9) were placed in the same desiccator with plates containing Aroclor-induced S9 only (no cells) and exposed to 1,3-butadiene gas, the cells were mutated. These experiments demonstrated that 1,3-butadiene is not a direct-acting mutagen as previously reported by de Meester et al. (1978) and that the mutagenic form of 1,3-butadiene is an oxidative metabolite of 1,3-butadiene, a volatile compound, and a base-pair substitution mutagen. The investigators suggested that epoxides are probably the ultimate mutagenic forms of 1,3-butadiene.

\section{TERATOGENICITY AND REPRODUCTIVE EFFECTS}

The fertility of rats was not severely impaired when they were exposed to 1,3-butadiene at concentrations of $600-6,700 \mathrm{ppm}$ for 7.5 hours per day, 6 days per week, for 8 months; however, the decreased fecundity observed may have been related to exposure. No evidence of degenerative testicular changes in males was seen, and all embryos appeared normal at necropsy (Carpenter et al., 1944). When female rats were exposed to 1,3-butadiene for 4 months at $45 \mathrm{ppm}$, increased embryonic mortality and teratogenesis were reported (Serebrennikov and Ogleznev, 1978). Pregnant female Sprague-
Dawley rats exposed to 1,3-butadiene at concentrations of $0,200,1,000$, or $8,000 \mathrm{ppm}$ for 6 hours per day during days 6-15 of gestation showed embryonic growth retardation and slight embryo mortality at all concentrations (Hazleton Labs Europe, 1981). At the highest exposure concentration, evidence of teratogenicity (major fetal defects such as cardiovascular, sternebral, and thoracic abnormalities) was seen.

\section{CARCINOGENICTY IN ANIMALS}

Groups of 100 Sprague-Dawley rats of each sex were exposed to 1,3-butadiene at concentrations of $0,1,000$, or 8,000 ppm for 6 hours per day, 5 days per week for 105-111 weeks (Hazleton Labs Europe, 1981). Significantly increased incidences of mammary gland tumors, Zymbal gland carcinomas, follicular cell tumors of the thyroid gland, and uterine stromal carcinomas in fmales and increased incidences of Leydig cell tumors and pancreatic exocrine tumors in males were observed. Survival was $20 \%$ for males at week 105 and $25 \%$ for females at week 111 .

\section{EFFECTS ON HUMANS}

Workers exposed to 1,3-butadiene at concentrations of $8,000 \mathrm{ppm}$ for 8 hours complained of eye irritation, blurred vision, coughing, and drowsiness (Carpenter et al, 1944). Routine examination of workers exposed to 1,3-butadiene for a number of years at concentrations of less than $500 \mathrm{ppm}$ revealed no overt adverse effects (Wilson and McCormick, 1954). Effects on the skin and on nervous, gastrointestinal, circulatory, and respiratory systems have been reported in workers in the synthetic rubber industry (Abdullaeva, 1973; Alekperov et al., 1970; Revnova, 1973) and workers exposed to 1,3-butadiene and other chemicals have reported headaches, irritability, cardiac pain, and general weakness (Mukhametova et al., 1976); details of exposure concentrations and duration were not provided.

Epidemiologic evaluations of the potential hazards associated with the production of synthetic rubber polymers showed marginal increases in the incidences of diseases of the lymphatic and hematopoietic systems in workers in one of three plants surveyed, but other suspect or known carcinogens were present (Meinhardt et al., 1978; McMichael et 
al., 1976). A NIOSH survey of two plants showed an overall mortality that was lower $(80 \%$ and $68 \%$ ) than that expected for the U.S. population; however, excessive but not significant mortality rates for specific categories of neoplasms of the lymphatic and hematopoietic systems were observed in workers in both plants (Meinhardt et al., 1982). In a study of the styrene-butadiene rubber polymer industry in the United States and Canada, male workers were found to have a low overall mortality compared with the general population; mortality rates from Hodgkin's disease and from cancers of the gastrointestinal tract, larynx, kidney, and testis were increased but not significantly (Matanoski et al., 1982).

The International Agency for Research on Cancer has evaluated the available evidence linking cancer in humans to occupational exposures in the rubber industry (IARC, 1982). The evidence for carcinogenicity to humans was considered sufficient for certain exposures and was summarized as: "A large number of retrospective follow-up studies of cohorts of rubber workers and case-control studies of individuals with cancer have been conducted in the US, the UK, Switzerland, Canada, Sweden and Finland. These studies indicate that an excess incidence of bladder tumours occurred in the UK, which was probably associated with exposure to aromatic amines of workers employed before 1950. The evidence is less strong for US workers. US workers, however, showed increased rates of lymphatic leukaemia, probably due to exposure to organic solvents. Stomach and lung cancer rates were elevated in both the US and UK studies. There is limited evidence that other cancers (skin, colon, prostate, lymphoma) are associated with work in the industry. Cancers of the brain, thyroid, pancreas and oesophagus have also been reported."

\section{REASON FOR TESTING}

1,3-Butadiene was tested because of its large production, the widespread exposure of the population, and the lack of long-term toxicity and carcinogenicity information. The chemical was tested only in mice because a 2-year inhalation study in rats (sponsored by the International Institute of Synthetic Rubber Producers, Inc.) was already in progress (now completed) at the time of chemical selection. 


\section{MATERIALS AND METHODS}

\section{PROCUREMENT AND CHARACTERIZATION OF}

1,3-BUTADIENE

GENERATION OF CHAMBER CONCENTRATIONS FOR THE SIXTY-ONE-WEEK STUDIES

FIFTEEN-DAY STUDIES

FOURTEEN-WEEK STUDIES

SIXTY-ONE-WEEK STUDIES

Study Design

Source and Specifications of Test Animals

Animal Maintenance

Clinical Examinations and Pathology

Statistical Methods 


\section{PROCUREMENT AND CHARACTERIZATION OF 1,3-BUTADIENE}

1,3-Butadiene (rubber grade, containing $0.02 \%$ t-butyl catechol) was obtained from Phillips Petroleum Co. The 1,3-butadiene was packaged in low-pressure steel cylinders as a liquefied gas under its own vapor pressure and stored at or slightly below room temperature in the testing laboratory throughout the studies. Lot no. Y-634 was used for the 15-day studies and lot nos. Y-634 and Y-679 were used for the 14-week studies, both at Industrial Biotest Laboratories. In the 61-week studies at Battelle Pacific Northwest Laboratories, several 5-gallon cylinders of 1,3-butadiene were used as an emergency resource (Table 1). Because some cylinders contained nitrogen as an inert blanket for the cylinder headspace, cylinders were briefly bled into a hood before being used.

A special acceptance and handling protocol for 1,3-butadiene cylinders was employed during the 61-week studies. 1,3-Butadiene was shipped at approximately 5-week intervals. Each cylinder was analyzed upon receipt and was considered acceptable for use in the study only if the 4-ethenylcyclohexene (4-vinyl-1-cyclohexene, referred to in this report as dimer) content was less than $100 \mathrm{ppm}$. The concentration of dimer, often found in commercial 1,3-butadiene, increases with time under normal storage conditions. Generally cylinders were used for no longer than 6 weeks to minimize the amount of dimer delivered to the exposure chambers (Appendix D). Three cylinders that had dimer contents of slightly more than $100 \mathrm{ppm}$ were used because replacement cylinders were not readily available.

Each lot of 1,3-butadiene was analyzed by infrared spectrometry and gas chromatography (Appendix D). Based on the peak area in the gas chromatogram, the percent purity of the various lots of 1,3-butadiene varied from $98.94 \%$ to $100 \%$. One of the impurities that was commonly observed had the same retention time as methane. A second impurity eluting right after 1,3-butadiene was also commonly observed. This impurity was not identified; the highest concentration observed was $0.24 \%$ (lot no. F-193). The amount of dimer was determined by a second gas chromatographic system.

\section{GENERATION OF CHAMBER CONCENTRATIONS FOR THE SIXTY. ONE-WEEK STUDIES}

During the 60- and 61-week studies, 1,3-butadiene gas was metered to the exposure chambers and diluted in the fresh air chamber inlets. The uniformity of the vapor concentration in the exposure chambers was measured periodically throughout the studies. The generation system is illustrated and described in Appendix E.

1,3-Butadiene concentrations in the chamber atmospheres were monitored 7-12 times during each exposure day with a photoionization detector (PID) for the first 150 days or with a gas chromatograph for the remainder of the studies. Weekly and monthly concentrations are presented in Appendix E. The exposure concentrations for the 61-week studies are summarized as follows:

\begin{tabular}{ccc}
$\begin{array}{c}\text { Target Concen- } \\
\text { tration (ppm) }\end{array}$ & $\begin{array}{c}\text { Average Chamber Con- } \\
\text { centration } \pm \text { Standard } \\
\text { Deviation (ppm) }\end{array}$ & $\begin{array}{c}\text { No. of } \\
\text { Samples }\end{array}$ \\
625 & $627 \pm 25$ & 2,406 \\
1,250 & $1,236 \pm 41$ & 2,415 \\
\hline
\end{tabular}

Throughout the studies, samples taken from the chambers several times each exposure day indicated that mean daily concentrations were within $3 \%-4 \%$ of the target concentrations. The distribution of mean daily concentrations are as follows:

\begin{tabular}{|c|c|c|}
\hline \multirow{2}{*}{$\begin{array}{c}\text { Range of } \\
\text { Target Concentra. } \\
\text { tion (percent of target } \\
\text { concentration) }\end{array}$} & \multicolumn{2}{|c|}{$\begin{array}{c}\text { No. of Days } \\
\text { Mean Within Range }\end{array}$} \\
\hline & $625 \mathrm{ppm}$ & $1,250 \mathrm{ppm}$ \\
\hline $\begin{array}{r}>110 \\
100.110 \\
90-100 \\
80-90 \\
70-80 \\
<70\end{array}$ & $\begin{array}{r}0 \\
157 \\
128 \\
1 \\
1 \\
0\end{array}$ & $\begin{array}{r}0 \\
84 \\
199 \\
4 \\
0 \\
0\end{array}$ \\
\hline
\end{tabular}


TABLE 1. EXPERIMENTAL DESIGN AND MATERIALS AND METHODS IN THE INHALATION STUDIES OF 1,3-BUTADIENE (a)

\begin{tabular}{|c|c|c|c|}
\hline & $\begin{array}{l}\text { Fifteen.Day } \\
\text { Studies }\end{array}$ & $\begin{array}{l}\text { Fourteen-Week } \\
\text { Studies }\end{array}$ & $\begin{array}{l}\text { Sixty-One-Week } \\
\text { Studies }\end{array}$ \\
\hline \multicolumn{4}{|c|}{ EXPERIMENTAL DESIGN } \\
\hline Testing Laboratory & $\begin{array}{l}\text { Industrial Biotest } \\
\text { Laboratories }\end{array}$ & Same as 15-d studies & $\begin{array}{l}\text { Battelle Pacific } \\
\text { Northwest Laboratories }\end{array}$ \\
\hline Size of Test Groups & $\begin{array}{l}5 \text { male and } 5 \text { female } \\
\text { mice }\end{array}$ & $\begin{array}{l}10 \text { male and } 10 \text { female } \\
\text { mice }\end{array}$ & $\begin{array}{l}50 \text { male and } 50 \text { female } \\
\text { mice }\end{array}$ \\
\hline Concentrations & $\begin{array}{l}0,625,1,250,2,500 \\
5,000, \text { or } 8.000 \mathrm{ppm} 1,3- \\
\text { butadiene via inhalation }\end{array}$ & $\begin{array}{l}0,625,1,250,2,500 \\
5,000, \text { or } 8,000 \text { ppm } 1,3- \\
\text { butadiene via inhalation; } \\
\text { restart-- } 0 \text { or } 8,000 \text { ppm }\end{array}$ & $\begin{array}{l}0,625 \text {, or } 1,250 \mathrm{ppm} 1,3- \\
\text { butadiene via inhalation }\end{array}$ \\
\hline Date of First Exposure & $3 / 4 / 77$ & 5/27/77; restart, $6 / 22 / 77$ & $4 / 15 / 81$ \\
\hline Date of Last Exposure & $3 / 17 / 77$ & $8 / 28 / 77 ;$ restart, $9 / 21 / 77$ & $\begin{array}{l}6 / 7 / 82 \text { (males); } 6 / 15 / 82 \\
\text { (females) }\end{array}$ \\
\hline Duration of Exposures & $6 \mathrm{~h} / \mathrm{d}, 5 \mathrm{~d} / \mathrm{wk}$ for $2 \mathrm{wk}$ & $\begin{array}{l}6 \mathrm{~h} / \mathrm{d}, 5 \mathrm{~d} / \mathrm{wk} \text {, for } 64 \text { or } 63 \\
\text { exposures (restart) }\end{array}$ & $\begin{array}{l}6 \mathrm{~h} / \mathrm{d}, 5 \mathrm{~d} / \mathrm{wk} \text { for } 60 \mathrm{wk} \\
\text { (males) or } 61 \mathrm{wk} \text { (females) }\end{array}$ \\
\hline $\begin{array}{l}\text { Type and Frequency of } \\
\text { Observation }\end{array}$ & $\begin{array}{l}\text { Observed } 1 \times d \text { for signs } \\
\text { of moribundity and } \\
\text { mortality; weighed on } \\
d 0,5,10 \text {, and } 15\end{array}$ & $\begin{array}{l}\text { Observed } 1 \times d \text { for signs } \\
\text { of moribundity and } \\
\text { mortality; weighed on } d 0 \text {, } \\
\text { then } 1 \times \text { wk }\end{array}$ & $\begin{array}{l}\text { Observed } 2 \times \mathrm{d} \text { for signs of } \\
\text { moribundity and mortality; } \\
\text { weighed } 1 \times \text { wk for } 12 \mathrm{wk} \text {, } \\
\text { then } 1 \times \text { mo }\end{array}$ \\
\hline $\begin{array}{l}\text { Necropsy and Histologic } \\
\text { Examination }\end{array}$ & $\begin{array}{l}\text { The following tissues } \\
\text { were examined during } \\
\text { necropsy of all animals: } \\
\text { gross lesions, skin, mandi- } \\
\text { bular lymph node, mam- } \\
\text { mary gland, salivary } \\
\text { gland, thigh muscle, } \\
\text { sciatic nerve, sternebrae, } \\
\text { vertebrae or femur, includ. } \\
\text { ing marrow, costochondral } \\
\text { junction (rib), thymus, } \\
\text { larynx and pharynx, } \\
\text { trachea, lungs and } \\
\text { bronchi, heart, thyroid } \\
\text { glands. parathyroids, } \\
\text { esophagus, stomach, } \\
\text { duodenum, jejunum, } \\
\text { ileum, colon, cecum, } \\
\text { rectum, mesenteric lymph } \\
\text { node, liver, gallbladder, } \\
\text { pancreas, spleen, kidneys, } \\
\text { adrenal glands, urinary } \\
\text { bladder, seminal vesicles/ } \\
\text { prostate/testes or } \\
\text { ovaries/uterus, nasal } \\
\text { cavity and nasal turbi- } \\
\text { nates, brain, pituitary, } \\
\text { spinal cord, eyes }\end{array}$ & $\begin{array}{l}\text { Necropsies performed on } \\
\text { all animals; tissues } \\
\text { examined: same as in } \\
\text { 14-d study; histopath } \\
\text { exam performed on all } \\
\text { controls, high dose, and } \\
\text { early deaths }\end{array}$ & $\begin{array}{l}\text { Complete necropsy and } \\
\text { histopath exam performed } \\
\text { on all animals; tissues } \\
\text { examined: gross lesions, } \\
\text { mandibular lymph node, } \\
\text { mammary gland, sterne- } \\
\text { brae including marrow, } \\
\text { thymus, trachea, lungs and } \\
\text { bronchi, heart, thyroid } \\
\text { glands, parathyroids, } \\
\text { esophagus, stomach, colon, } \\
\text { small intestine ( } 2 \text { sections), } \\
\text { liver, gallbladder, pancreas, } \\
\text { spleen, kidneys, adrenal } \\
\text { glands, urinary bladder. } \\
\text { prostate/testes or } \\
\text { ovaries/uterus, nasal cavity } \\
\text { and nasal turbinates } 13 \text { sec- } \\
\text { tions), brain ( } 3 \text { sections). } \\
\text { pituitary, pharynx, and (if } \\
\text { abnormalleyes }\end{array}$ \\
\hline
\end{tabular}


TABLE 1. EXPERIMENTAL DESIGN AND MATERIALS AND METHODS IN THE INHALATION STUDIES OF 1,3-BUTADIENE (Continued)

\begin{tabular}{|c|c|c|c|}
\hline & $\begin{array}{l}\text { Fifteen-Day } \\
\text { Studies }\end{array}$ & $\begin{array}{c}\text { Fourteen.Week } \\
\text { Studies }\end{array}$ & $\begin{array}{l}\text { Sixty-One-Week } \\
\text { Studies }\end{array}$ \\
\hline \multicolumn{4}{|c|}{ ANIMALS AND ANIMAL MAINTENANCE } \\
\hline Species & $\mathrm{B}_{6} \mathrm{C}_{3} \mathrm{~F}_{1}$ mice & $\mathrm{B} 6 \mathrm{C} 3 \mathrm{~F}_{1}$ mice & $\mathrm{B}_{6 \mathrm{C}} 3 \mathrm{~F}_{1}$ mice \\
\hline Animal Source & $\begin{array}{l}\text { Frederick Cancer } \\
\text { Research Center } \\
\text { (Frederick, MD) }\end{array}$ & $\begin{array}{l}\text { Frederick Cancer } \\
\text { Research Center } \\
\text { (Frederick, MD) }\end{array}$ & $\begin{array}{l}\text { Charles River Breeding } \\
\text { Labs (Portage, MI) }\end{array}$ \\
\hline $\begin{array}{l}\text { Time Held Before } \\
\text { Start of Test }\end{array}$ & $14 d$ & $8 \mathrm{~d}$; restart, $13 \mathrm{~d}$ & $21 \mathrm{~d}$ \\
\hline $\begin{array}{l}\text { Age When Placed } \\
\text { on Study }\end{array}$ & Approximately $5 \mathrm{wk}$ & Approximately 4.5 wk & $8-9 \mathrm{wk}$ \\
\hline Age When Killed & Approximately $7 \mathrm{wk}$ & Approximately $18-19 w \mathrm{k}$ & $\begin{array}{l}\text { 68-69 wk (males); } 69-70 \\
\text { wk (females) }\end{array}$ \\
\hline Necropsy Dates & $3 / 18 / 77$ & $\begin{array}{l}8 / 29 / 77 ; \\
\text { restart, } 9 / 22 / 77\end{array}$ & $\begin{array}{l}\text { 6/8/82 (males); } \\
\text { 6/16/82 (females) }\end{array}$ \\
\hline Method of Distribution & $\begin{array}{l}\text { According to a table } \\
\text { of random numbers }\end{array}$ & Same as 15-d studies & $\begin{array}{l}\text { Distributed to weight } \\
\text { blocks, then to groups } \\
\text { according to table of } \\
\text { random numbers }\end{array}$ \\
\hline Feed & $\begin{array}{l}\text { Wayne Lab-Blox } \\
\text { (Allied Mills, Inc., } \\
\text { Chicago, IL); freely } \\
\text { available except } \\
\text { during inhalation } \\
\text { exposure }\end{array}$ & Same as $15 \cdot d$ studies & $\begin{array}{l}\text { NIH } 07 \text { diet (Ziegler Bros, } \\
\text { Gardners, PA); freely } \\
\text { available except during } \\
\text { inhalation exposure; } \\
\text { Wayne Lab-Blox for } 2 \text { wk }\end{array}$ \\
\hline Water & Provided ad libitum & Provided ad libitum & $\begin{array}{l}\text { Tap water freely available } \\
\text { through automatic } \\
\text { watering system (Edstrom } \\
\text { Industries, Waterford, WI) }\end{array}$ \\
\hline Cages & $\begin{array}{l}\text { Stainless steel mesh } \\
\text { (Unifab Corp., } \\
\text { Kalamazoo, MI) }\end{array}$ & Same as 15-d studies & $\begin{array}{l}\text { Stainless steel wire (Lab } \\
\text { Products, Rochelle Pk, NJ) }\end{array}$ \\
\hline Cage Rotation & None & None & $\begin{array}{l}\text { Rotated last } 5 \text { mo of } \\
\text { studies }\end{array}$ \\
\hline Animals per Cage & 1 & 1 & 1 \\
\hline
\end{tabular}


TABLE 1. EXPERIMENTAL DESIGN AND MATERIALS AND METHODS IN THE INHALATION STUDIES OF 1,3-BUTADIENE (Continued)

\begin{tabular}{|c|c|c|c|}
\hline & $\begin{array}{l}\text { Fifteen-Day } \\
\text { Studies }\end{array}$ & $\begin{array}{c}\text { Fourteen-Week } \\
\text { Studies }\end{array}$ & $\begin{array}{l}\text { Sixty-One-Week } \\
\text { Studies }\end{array}$ \\
\hline $\begin{array}{l}\text { Animal Room } \\
\text { Environment }\end{array}$ & $\begin{array}{l}\text { Fluorescent light } \\
12 \mathrm{~h} / \mathrm{d} \text {; information on } \\
\text { temperature, air } \\
\text { changes, and humidity } \\
\text { not available }\end{array}$ & $\begin{array}{l}\text { Fluorescent light } 12 \mathrm{~h} / \mathrm{d} \text {; } \\
\text { information on } \\
\text { temperature, air changes, } \\
\text { and humidity not } \\
\text { available }\end{array}$ & 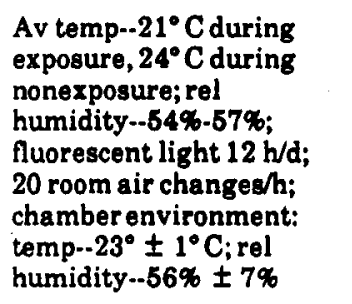 \\
\hline $\begin{array}{l}\text { Other Chemicals on } \\
\text { Test in Same Room }\end{array}$ & Propylene & Propylene & $\begin{array}{l}\text { Ethylene Oxide } \\
\text { 1,2-Epoxybutane }\end{array}$ \\
\hline \multicolumn{4}{|l|}{ CHEMISTRY } \\
\hline Lot No. Used & $Y .634$ & $Y-634, Y-679$ & $\begin{array}{l}\text { B-915, B-899B, B-962, } \\
\text { B-996, F-037, F-047, } \\
\text { F-089A, F-089B, F-089C, } \\
\text { F-120, F-159, F-193, F-207 }\end{array}$ \\
\hline $\begin{array}{l}\text { Date of Initial Use of } \\
\text { Subsequent Lots }\end{array}$ & N/A & $6 / 24 / 77$ & $\begin{array}{l}4 / 15 / 81,5 / 12 / 81,6 / 15 / 81 \\
7 / 13 / 81,8 / 25 / 81,9 / 14 / 81 \\
11 / 10 / 81,12 / 14 / 81 \\
12 / 15 / 81,1 / 18 / 82,2 / 22 / 82 \\
4 / 2 / 82,4 / 23 / 82\end{array}$ \\
\hline Supplier & $\begin{array}{l}\text { Phillips Petroleum Co. } \\
\text { (Phillips, TX) }\end{array}$ & Same as 15 -d studies & Same as $15-d$ studies \\
\hline \multicolumn{4}{|l|}{ CHEMICAL/VEHICLE } \\
\hline Preparation & $\begin{array}{l}\text { Test material was } \\
\text { metered into the } \\
\text { chamber air supply so } \\
\text { that it was well mixed } \\
\text { with incoming air by } \\
\text { turbulence }\end{array}$ & Same as 15 -d studies & Same as $15 \cdot d$ studies \\
\hline
\end{tabular}

(a) No single-exposure studies were conducted. 


\section{FIFTEEN-DAY STUDIES}

Male and female $\mathrm{B} 6 \mathrm{C} 3 \mathrm{~F}_{1}$ mice were obtained from Frederick Cancer Research Center and observed for 14 days before being placed on study at Industrial Biotest Laboratories. Groups of five mice of each sex were exposed to air containing 1,3-butadiene at target concentrations of $0,625,1,250,2,500,5,000$, or $8,000 \mathrm{ppm}$ for 6 hours per day, 5 days per week for 2 weeks. Mice were observed daily for signs of moribundity and mortality and were weighed on days $0,5,10$, and 15. Necropsies were performed on all animals. Details of animal maintenance are presented in Table 1.

\section{FOURTEEN-WEEK STUDIES}

Fourteen-week studies were conducted at Industrial Biotest Laboratories to evaluate the cumulative effects of 1,3-butadiene and to determine the concentrations to be used in the intended 2-year studies. Three- to four-week-old male and female mice were obtained from Frederick Cancer Research Center, observed for 8 days or 13 days (a supplemental study was started because most of the males in the highest dose group died) and then assigned to groups according to a table of random numbers. Feed and water were freely available, except during exposure periods, when water only was available.

Groups of 10 mice of each sex were exposed to air containing 1,3-butadiene at concentrations of 0 , $625,1,250,2,500,5,000$, or $8,000 \mathrm{ppm}, 6$ hours per day, 5 days per week for 14 weeks (64 exposures). Because four male mice in the highest dose group were dead by day 4 , another two groups of 10 male mice each were started: a group of controls and an 8,000-ppm exposure group. Further experimental details are summarized in Table 1.

Animals were checked once per day for signs of moribundity and mortality; moribund animals were killed. Body weights were recorded weekly. At the end of the 95-day or 93-day (restart) studies, survivors were killed. Necropsies were performed on all animals, except those excessively autolyzed or cannibalized. Tissues and groups examined are listed in Table 1.

\section{SIXTY-ONE-WEEK STUDIES}

\section{Study Design}

Two long-term studies were initiated at Battelle Pacific Northwest Laboratories. Groups of 50 mice of each sex were exposed 6 hours per day, 5 days per week to air containing 1,3-butadiene at target concentrations of 0,625 , or $1,250 \mathrm{ppm}$. The first study was terminated after 13 weeks because the low dose group had been exposed inadvertently at the same concentration as the high dose group. No clinical signs or mortality were observed in these animals. After study termination, all animals were examined grossly and 10 animals from each sex and dose group were selected randomly for histopathologic examination. No compound-related lesions were observed. The second study was intended to last 103 weeks but was terminated after 60 weeks (males) or 61 weeks (females) because of low survival. Results of this second study are given and interpreted in this Technical Report.

\section{Source and Specifications of Test Animals}

The male and female $\mathrm{B}_{6 \mathrm{C}} 3 \mathrm{~F}_{1}(\mathrm{C} 57 \mathrm{BL} / 6 \mathrm{~N} \times$ $\mathrm{C} 3 \mathrm{H} / \mathrm{HeN} \mathrm{MTV}^{-}$) mice used in this study were produced under strict barrier conditions at Charles River Breeding Laboratories under a contract to the Carcinogenesis Program. Breeding starts for the foundation colony at the production facility originated at the National Institutes of Health Repository. Animals shipped for testing were progeny of defined microflora-associated parents that were transferred from isolators to barrier maintained rooms. Animals were shipped to the testing laboratory at 5-6 weeks of age. The animals were quarantined at the testing facility for 3 weeks. Thereafter, a complete pathologic examination was performed on a selected number of animals to assess their health. The rodents were placed on study at 8-9 weeks of age. The health of the animals was monitored during the course of the study. Results of serologic analyses for murine viruses in the control animals at the end of the studies are given in Appendix F. 
A quality control skin grafting program has been in effect since early 1978 to monitor the genetic integrity of the inbred mice used to produce the hybrid $\mathrm{B} 6 \mathrm{C} 3 \mathrm{~F}_{1}$ test animal. In mid1981, data were obtained that showed incompatibility between the $\mathrm{NIH} \mathrm{C} 3 \mathrm{H}$ reference colony and the $\mathrm{C} 3 \mathrm{H}$ colony from a Program supplier. In August 1981, inbred parental lines of mice were further tested for genetic integrity via isozyme and protein electrophoretograms that demonstrate phenotype expressions of known genetic loci.

The C57BL/6 mice were homogeneous at all loci tested. Eighty-five percent of the $\mathrm{C} 3 \mathrm{H}$ mice monitored were variant at one to three loci, indicating some heterogeneity in the $\mathrm{C} 3 \mathrm{H}$ line from this supplier. Nevertheless, the genome of this line is more homogeneous than that of randomly bred stocks.

Male mice from the $\mathrm{C} 3 \mathrm{H}$ colony and female mice from the $\mathrm{C} 57 \mathrm{BL} / 6$ colony were used as parents for the hybrid $\mathrm{B} 6 \mathrm{C}_{3} \mathrm{~F}_{1}$ mice used in these studies. The influence of the potential genetic nonuniformity in the hybrid mice on these results is not known, but results of the studies are not affected because matched concurrent controls were included in each study.

\section{Animal Maintenance}

Mice were housed individually in stainless steel cages within the exposure chambers. Feed (Appendix G) and water were freely available except during exposure periods, when only water was available. Details of animal maintenance are summarized in Table 1.

\section{Clinical Examinations and Pathology}

All animals were observed twice daily for signs of moribundity or mortality. Clinical signs were recorded once per week. Individual body weights were recorded once per week for the first 12 weeks of the study and once per month thereafter. Mean body weights were determined for each group. Examination of mice for palpable masses began 6 months after the study started and continued monthly thereafter. Moribund animals were killed, as were animals that survived to the end of the study. Necropsies were performed on all animals, including those found dead, unless they were excessively autolyzed or cannibalized. Thus, the number of animals from which particular organs or tissues were examined microscopically varies and is not necessarily equal to the number of animals that were placed on study in each group.

Examinations for grossly visible lesions were performed on major tissues or organs. Tissues were preserved in $10 \%$ neutral buffered formalin, embedded in paraffin, sectioned, and stained with hematoxylin and eosin. Three separate sections of nasal turbinate were examined. Section one was at the level just caudal to the incisor teeth, section two was midway between the incisors and first molar, and section three was at the middle of the second molar. Tissues examined microscopically are listed in Table 1.

When the pathology examination was completed, the slides, individual animal data records, and summary tables were sent to an independent quality assurance laboratory. Individual animal records and tables were compared for accuracy, slides and tissue counts were verified, and histotechnique was evaluated. All tumor diagnoses, all target tissues, and all tissues from a randomly selected $10 \%$ of the animals were evaluated by a quality assurance pathologist. Slides of all target tissues and those about which the original and quality assurance pathologists disagreed were submitted to the Chairperson of the NTP Pathology Working Group (PWG) for evaluation. Representative coded slides selected by the Chairperson were reviewed by PWG pathologists, who reached a consensus and compared their findings with the original and quality assurance diagnoses. When diagnostic differences were found, the PWG sent the appropriate slides and comments to the original pathologist for review. This procedure has been described, in part, by Maronpot and Boorman (1982) and Boorman et al. (In Press). The final diagnoses represent a consensus of contractor pathologists and the NTP Pathology Working Group.

Nonneoplastic lesions are not specifically examined routinely by the quality assurance pathologist or the PWG. Certain nonneoplastic findings are reviewed by the quality assurance pathologist and the PWG if they are considered part of the toxic response to a chemical or if they are deemed of special interest. 


\section{Statistical Methods}

Data Recording: Data on this experiment were recorded in the Carcinogenesis Bioassay Data System (Linhart et al., 1974). The data elements include descriptive information on the chemicals, animals, experimental design, survival, body weight, and individual pathologic results, as recommended by the International Union Against Cancer (Berenblum, 1969).

Survival Analyses: The probability of survival was estimated by the product-limit procedure of Kaplan and Meier (1958) and is presented in the form of graphs. Animals were censored from the survival analyses at the time they were found dead of other than natural causes or were found to be missing; animals dying from natural causes were not censored. Statistical analyses for a possible dose-related effect on survival used the method of Cox (1972) for testing two groups for equality and Tarone's (1975) extensions of Cox's method for testing for a dose-related trend. All reported $P$ values for the survival analysis are two-sided.

Calculation of Incidence: The incidence of neoplastic or nonneoplastic lesions has been given as the ratio of the number of animals bearing such lesions at a specific anatomic site to the number of animals in which that site was examined. In most instances, the denominators included only those animals for which the site was examined histologically. However, when macroscopic examination was required to detect lesions (e.g., skin or mammary tumors) prior to histologic sampling, or when lesions could have appeared at multiple sites (e.g., lymphomas), the denominators consist of the number of animals on which necropsies were performed.

Analysis of Tumor Incidence: Three statistical methods are generally used to analyze tumor incidence data. The two that adjust for intercurrent mortality employ the classical method for combining contingency tables developed by Mantel and Haenszel (1959). Tests of significance included pairwise comparisons of high dose and low dose groups with controls and tests for overall dose-response trends.

Life Table Analyses--The first method of analysis assumed that all tumors of a given type observed in animals dying before the end of the study were "fatal"; i.e., they either directly or indirectly caused the death of the animal. According to this approach, the proportions of tumor-bearing animals in the dosed and control groups were compared at each point in time at which an animal died with a tumor of interest. The denominators of these proportions were the total number of animals in each group examined during the time period. These results, including the data from animals killed at the end of the study, were then combined by the MantelHaenszel method to obtain an overall $P$ value. This method of adjusting for intercurrent mortality is the life table method of Cox (1972) and of Tarone (1975).

Incidental Tumor Analyses--This method, which is appropriate for nonfatal tumors (Peto et al., 1980), was not employed for these data, since the marked survival differences between dosed and control groups reduced the sensitivity of this procedure for detecting carcinogenic effects.

Unadjusted Analyses--In addition to the life table analyses, the results of the Fisher's exact test for pairwise comparisons and the CochranArmitage linear trend test (Armitage, 1971; Gart et al., 1979) are presented. These two tests are based on the overall proportion of tumorbearing animals and do not adjust for survival differences. All reported $P$ values for tumor analyses are one-sided. 


\section{RESULTS}

FIFTEEN-DAY STUDIES

FOURTEEN-WEEK STUDIES

SIXTY-ONE-WEEK STUDIES

Body Weights and Clinical Signs

Survival

Pathology and Statistical Analyses of Results 


\section{FIFTEEN·DAY STUDIES}

All mice survived to the end of the exposure period. Male mice that were exposed to 1,3-butadiene at $1,250 \mathrm{ppm}$ or more and female mice that were exposed at 5,000 or $8,000 \mathrm{ppm}$ lost weight between days 10 and 15 . The mean body weights of males and females that were exposed at 5,000 or $8,000 \mathrm{ppm}$ were lower on day 15 than on day 0 (Table 2). No compound-related effects were observed at necropsy.

TABLE 2. SURVIVAL AND MEAN BODY WEIGHTS OF MICE IN THE FIFTEEN.DAY INHALATION STUDIES OF 1,3-BUTADIENE

\begin{tabular}{|c|c|c|c|c|c|}
\hline $\begin{array}{l}\text { Concentration } \\
\text { (ppm) }\end{array}$ & Survival(a) & $\frac{\text { Mean }}{\text { Initial }}$ & $\frac{\text { ody Weight }}{\text { Final }}$ & $\frac{\text { ams) }}{\text { Change (b) }}$ & $\begin{array}{c}\text { Final BodyWeight } \\
\text { Relative to } \\
\text { Controls (c) } \\
\text { (percent) }\end{array}$ \\
\hline \multicolumn{6}{|l|}{ MALE } \\
\hline $\begin{array}{r}0 \\
625 \\
1,250 \\
2,500 \\
5,000 \\
8,000\end{array}$ & $\begin{array}{l}5 / 5 \\
5 / 5 \\
5 / 5 \\
5 / 5 \\
5 / 5 \\
5 / 5\end{array}$ & $\begin{array}{l}22.8 \pm 1.0 \\
23.4 \pm 0.4 \\
23.4 \pm 0.5 \\
23.4 \pm 0.5 \\
22.6 \pm 1.4 \\
23.2 \pm 0.7\end{array}$ & $\begin{array}{l}25.8 \pm 0.6 \\
26.0 \pm 0.0 \\
25.4 \pm 0.2 \\
24.6 \pm 0.7 \\
21.6 \pm 1.5 \\
23.2 \pm 0.4\end{array}$ & $\begin{array}{r}+3.0 \pm 1.0 \\
+2.6 \pm 0.4 \\
+2.0 \pm 0.6 \\
+1.2 \pm 0.8 \\
-1.0 \pm 0.6 \\
0.0 \pm 0.6\end{array}$ & $\begin{aligned} & . \\
+ & 0.8 \\
- & 1.6 \\
- & 4.7 \\
- & 16.3 \\
- & 10.1\end{aligned}$ \\
\hline \multicolumn{6}{|l|}{ FEMALE } \\
\hline $\begin{array}{r}0 \\
625 \\
1,250 \\
2,500 \\
5,000 \\
8,000\end{array}$ & $\begin{array}{l}5 / 5 \\
5 / 5 \\
5 / 5 \\
5 / 5 \\
5 / 5 \\
5 / 5\end{array}$ & $\begin{array}{l}19.8 \pm 0.6 \\
20.0 \pm 0.5 \\
20.0 \pm 0.7 \\
20.0 \pm 0.7 \\
20.2 \pm 0.7 \\
20.0 \pm 0.7\end{array}$ & $\begin{array}{l}23.6 \pm 0.8 \\
22.6 \pm 0.4 \\
21.8 \pm 0.7 \\
22.2 \pm 0.4 \\
19.4 \pm 1.1 \\
19.6 \pm 0.2\end{array}$ & $\begin{array}{l}+3.8 \pm 1.2 \\
+2.6 \pm 0.2 \\
+1.8 \pm 0.7 \\
+2.2 \pm 1.0 \\
-0.8 \pm 0.7 \\
-0.4 \pm 0.5\end{array}$ & $\begin{aligned} & . \\
- & 4.2 \\
- & 7.6 \\
- & 5.9 \\
- & 17.8 \\
- & 16.9\end{aligned}$ \\
\hline
\end{tabular}

(a) Number surviving/number initially in the group

(b) Mean weight change of the group \pm standard error of the mean

(c) Final weight of the dosed survivors relative to the survivors of the controls = Final Body Weight (Dosed Group) - Final Body Weight (Control Group) $\times 100$ Final Body Weight (Control Group) 


\section{FOURTEEN-WEEK STUDIES}

Six of 10 males and $1 / 10$ females that were exposed at $8,000 \mathrm{ppm}, 6 / 10$ males and $1 / 10$ females exposed at $5,000 \mathrm{ppm}$, and $1 / 10$ males exposed at 1,250 or $2,500 \mathrm{ppm}$ died or were killed in a moribund condition (Table 3 ). In addition, one male and one female exposed at $625 \mathrm{ppm}$ died as a result of accidents. Body weight gains were decreased in males at the three highest concentrations and in females at the two highest concentrations. In the supplemental study, $6 / 10$ males exposed at $8,000 \mathrm{ppm}$ died; the survivors lost weight. No compound-related histopathologic effects were observed. Because of the mortality and the depressions in weight gain observed in mice exposed at 2,500 ppm, concentrations of 625 and $1,250 \mathrm{ppm} \mathrm{1,3-}$ butadiene were selected for mice in the 2-year studies.

TABLE 3. SURVIVAL AND MEAN BODY WEIGHTS OF MICE IN THE FOURTEEN-WEEK INHALATION STUDIES OF 1,3-BUTADIENE

\begin{tabular}{cccc}
\hline $\begin{array}{c}\text { Concentration } \\
(\text { ppm) }\end{array}$ & Survival(a) & Mean Body Weight (grams) & $\begin{array}{c}\text { Final BodyWeight } \\
\text { Relative to } \\
\text { Controls (d) } \\
\text { (percent) }\end{array}$ \\
\cline { 3 - 4 }
\end{tabular}

MALE

$\begin{array}{rrrrrr}0 & 10 / 10 & 17.0 \pm 0.5 & 30.6 \pm 0.4 & +13.6 \pm 0.5 & - \\ 625 & \text { (e) } 9 / 10 & 17.6 \pm 0.5 & 29.9 \pm 0.4 & +12.1 \pm 0.6 & -2.3 \\ 1,250 & 9 / 10 & 16.6 \pm 0.5 & 30.9 \pm 0.6 & +14.1 \pm 0.5 & -1.0 \\ 2,500 & 9 / 10 & 17.0 \pm 0.5 & 26.7 \pm 0.7 & +9.5 \pm 0.4 & -12.7 \\ 5,000 & 4 / 10 & 17.2 \pm 0.4 & 23.0 \pm 0.7 & +6.5 \pm 1.0 & -24.8 \\ 8,000 & 4 / 10 & 17.5 \pm 0.6 & 19.5 \pm 1.7 & +3.2 \pm 1.0 & -36.3 \\ & & & & - \\ \text { (f) } 0 & 10 / 10 & 20.8 \pm 0.3 & 30.9 \pm 0.8 & +10.1 \pm 0.7 & -38.5\end{array}$

FEMALE

\begin{tabular}{rrrrrr}
0 & $10 / 10$ & $15.0 \pm 0.3$ & $27.3 \pm 0.4$ & $+12.3 \pm 0.5$ & \\
625 & $(\mathrm{e}) 9 / 10$ & $14.9 \pm 0.3$ & $25.9 \pm 1.1$ & $+10.9 \pm 1.3$ & -5.1 \\
1,250 & $10 / 10$ & $14.6 \pm 0.4$ & $27.3 \pm 0.3$ & $+12.7 \pm 0.3$ & 0.0 \\
2.500 & $10 / 10$ & $14.8 \pm 0.4$ & $25.8 \pm 0.4$ & $+11.0 \pm 0.3$ & -5.5 \\
5,000 & $9 / 10$ & $15.0 \pm 0.4$ & $24.1 \pm 0.7$ & $+9.2 \pm 0.7$ & -11.7 \\
8,000 & $9 / 10$ & $15.7 \pm 0.3$ & $22.1 \pm 0.5$ & $+6.4 \pm 0.5$ & -19.0 \\
\hline
\end{tabular}

(a) Number surviving/number initially in the group

(b) Initial mean body weight of all animals in the group. Subsequent calculations are based on those animals surviving to the end of the study.

(c) Mean weight change of the survivors of the group \pm standard error of the mean

(d) Final weight of the dosed survivors relative to the survivors of the controls $=$

Final Body Weight (Dosed Group) - Final Body Weight (Control Group) $\times 100$

(e) Accidental death Final Body Weight (Control Group)

(f) Restart mice 


\section{SIXTY-ONE-WEEK STUDIES}

\section{Body Weights and Clinical Signs}

Body weights were not affected by inhalation exposure to 1,3-butadiene. Due to an apparent inadequate randomization, initial weights in dosed male and female mice were 9\%-11\% higher than those of the controls $(P<0.01$ by
Mann-Whitney $U$ test), and these approximate relationships were seen throughout much of the studies (Table 4 and Figure 1). There were no characteristic clinical signs observed other than those associated with tumor development and moribundity.

TABLE 4. MEAN BODY WEIGHTS AND SURVIVAL OF MICE IN THE SIXTY-ONE-WEEK INHALATION STUDIES OF 1,3-BUTADIENE

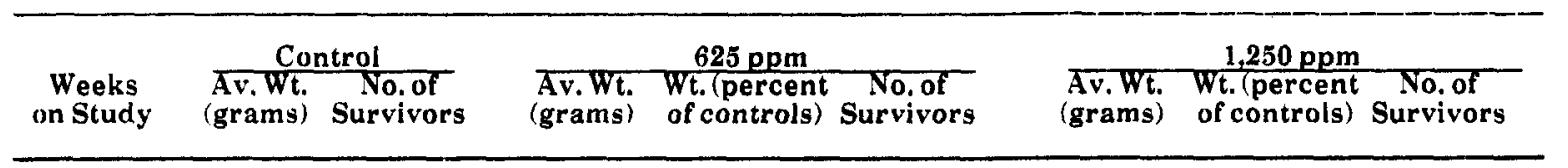

\section{MALE}

$\begin{array}{rll}0 & 23 & 50 \\ 1 & 26 & 50 \\ 2 & 27 & 50 \\ 3 & 28 & 50 \\ 4 & 27 & 50 \\ 5 & 28 & 50 \\ 6 & 29 & 50 \\ 7 & 29 & 50 \\ 8 & 31 & 50 \\ 9 & 29 & 50 \\ 10 & 30 & 50 \\ 11 & 31 & 50 \\ 12 & 31 & 50 \\ 16 & 33 & 50 \\ 22 & 32 & 50 \\ 26 & 34 & 50 \\ 30 & 35 & 50 \\ 36 & 35 & 50 \\ 40 & 34 & 50 \\ 44 & 36 & 50 \\ 48 & 34 & 50 \\ 53 & 35 & 50 \\ 56 & 36 & 49 \\ 58 & 36 & 49\end{array}$

$\begin{array}{lr}25 & 108.7 \\ 26 & 100.0 \\ 26 & 96.3 \\ 27 & 96.4 \\ 29 & 107.4 \\ 28 & 100.0 \\ 28 & 96.6 \\ 28 & 96.6 \\ 29 & 93.5 \\ 31 & 106.9 \\ 32 & 106.7 \\ 31 & 100.0 \\ 30 & 96.8 \\ 32 & 97.0 \\ 34 & 106.3 \\ 35 & 102.9 \\ 36 & 102.9 \\ 36 & 102.9 \\ 36 & 105.9 \\ 35 & 97.2 \\ 35 & 102.9 \\ 36 & 102.9 \\ 38 & 105.6 \\ 36 & 100.0\end{array}$

50
50
50
50
50
50
50
50
50
50
49
49
49
49
49
46
44
39
35
32
26
24
18
13

$\begin{array}{lrr}25 & 108.7 & 50 \\ 26 & 100.0 & 50 \\ 27 & 100.0 & 50 \\ 27 & 96.4 & 50 \\ 27 & 100.0 & 50 \\ 28 & 100.0 & 50 \\ 29 & 100.0 & 50 \\ 29 & 100.0 & 50 \\ 31 & 100.0 & 50 \\ 31 & 106.9 & 50 \\ 31 & 103.3 & 50 \\ 32 & 103.2 & 50 \\ 32 & 103.2 & 49 \\ 34 & 103.0 & 49 \\ 37 & 115.6 & 44 \\ 37 & 108.8 & 41 \\ 39 & 111.4 & 38 \\ 40 & 114.3 & 37 \\ 40 & 117.6 & 32 \\ 40 & 111.1 & 27 \\ 40 & 117.6 & 22 \\ 36 & 102.9 & 14 \\ 39 & 108.3 & 9 \\ 41 & 113.9 & 7\end{array}$

FEMALE

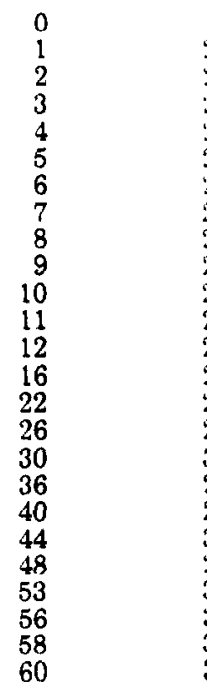

$\begin{array}{ll}18 & 50 \\ 21 & 50 \\ 21 & 50 \\ 23 & 49 \\ 23 & 49 \\ 24 & 49 \\ 24 & 49 \\ 24 & 48 \\ 26 & 48 \\ 26 & 48 \\ 27 & 48 \\ 27 & 48 \\ 26 & 48 \\ 28 & 48 \\ 28 & 48 \\ 29 & 48 \\ 30 & 47 \\ 27 & 47 \\ 29 & 47 \\ 31 & 47 \\ 29 & 46 \\ 31 & 46 \\ 31 & 46 \\ 30 & 46 \\ 31 & 46\end{array}$

111.1

104.8
109.5

104.3

104.2

100.0

100.0

100.0

100.0

96.3

96.3

103.8

96.

103.6

103.4

96.7

111.1

106.9

100.0

110.3

106.5

106.5

110.0

109.7

50
50
48
48
48
48
48
48
48
48
48
48
48
48
48
48
46
44
40
39
35
32
23
19
16

111.1

100.0

95.2

100.0

104.3

95.8

95.8

104.2

100.0

96.2

92.6

100.0

96.2

92.9

100.0

100.0

93.3

107.4

103.4

103.2

113.8

103.2

106.5

110.0

109.7

50
50
50
50
50
50
50
50
50
50
50
50
50
50
48
48
48
48
47
45
43
42
36
35
31



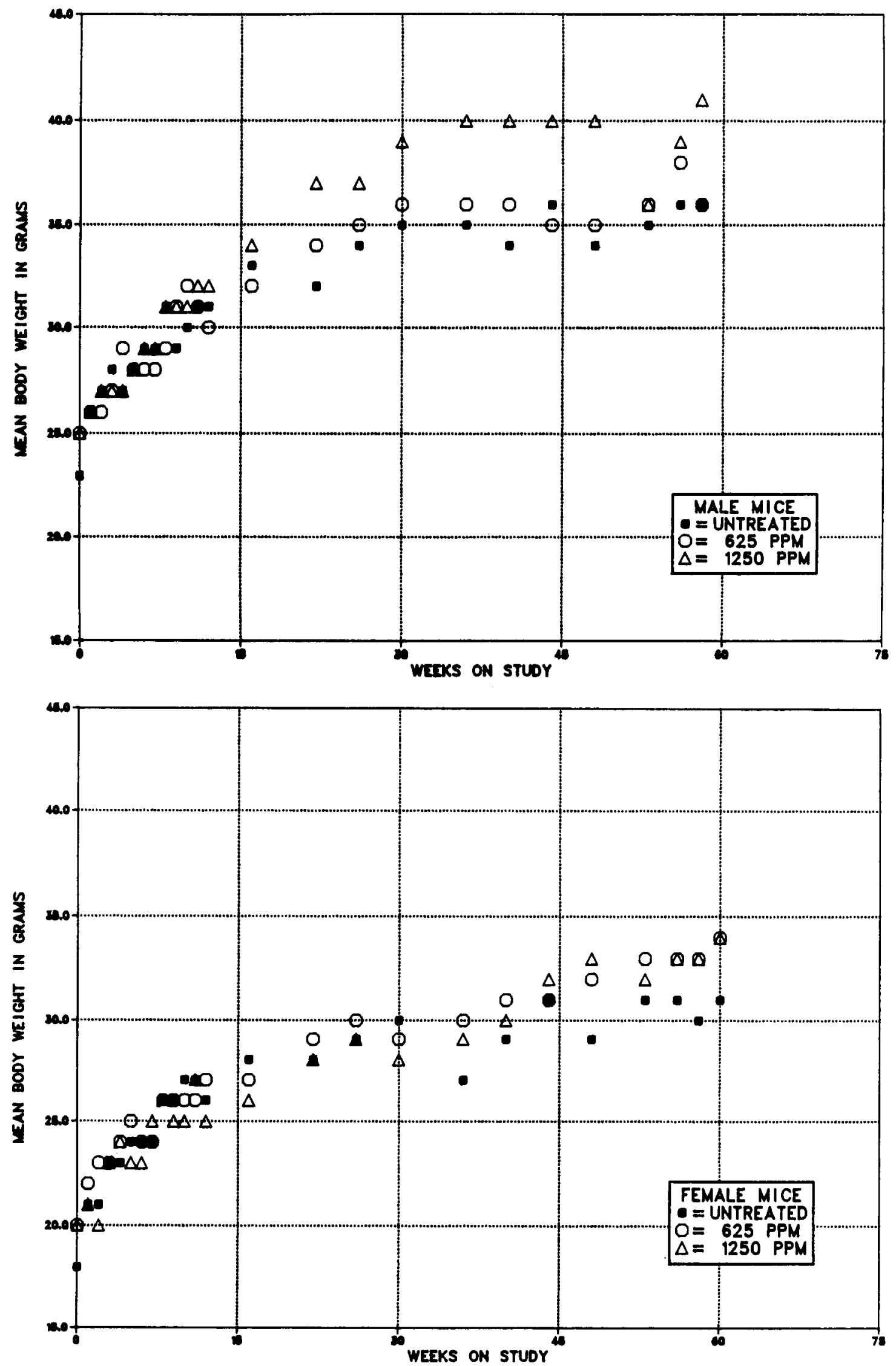

FIGURE 1. GROWTH CURVES FOR MICE EXPOSED TO 1,3-BUTADIENE BY INHALATION FOR SIXTY-ONE WEEKS 


\section{RESULTS}

\section{Survival}

Estimates of the probabilities of survival of male and female mice exposed to 1,3-butadiene at the concentrations used in these studies and those of the controls are shown in the Kaplan and Meier curves in Figure 2. The survival of both dosed

groups of mice of each sex was significantly less than that of the corresponding controls (Table 5). The 2-year studies were later abbreviated to 60 weeks for males and 61 weeks for females because of poor survival.

TABLE 5. SURVIVAL OF MICE IN THE SIXTY.ONE.WEEK INHALATION STUDIES OF 1,3-BUTADIENE

\begin{tabular}{|c|c|c|c|}
\hline & Control & 625 ppm & $1,250 \mathrm{ppm}$ \\
\hline \multicolumn{4}{|l|}{ MALE (a) } \\
\hline $\begin{array}{l}\text { Animals Initially in Study } \\
\text { Nonaccidental Deaths Before Termination (b) } \\
\text { Accidentally Killed } \\
\text { Killed at Termination } \\
\text { Survival P Values (d) }\end{array}$ & $\begin{array}{l}50 \\
1 \\
0 \\
49 \\
<0.001\end{array}$ & $\begin{array}{r}50 \\
39 \\
0 \\
11 \\
<0.001\end{array}$ & $\begin{array}{r}50 \\
39 \\
\text { (c) } 4 \\
7 \\
<0.001\end{array}$ \\
\hline \multicolumn{4}{|l|}{ FEMALE (a) } \\
\hline $\begin{array}{l}\text { Animals Initially in Study } \\
\text { Nonaccidental Deaths Before Termination (b) } \\
\text { Accidentally Killed } \\
\text { Animals Missing } \\
\text { Killed at Termination } \\
\text { Died During Termination Period } \\
\text { Survival P Values (d) }\end{array}$ & $\begin{array}{c}50 \\
4 \\
0 \\
0 \\
46 \\
0 \\
<0.001\end{array}$ & $\begin{array}{r}50 \\
32 \\
3 \\
0 \\
14 \\
1 \\
<0.001\end{array}$ & $\begin{array}{l}50 \\
18 \\
1 \\
1 \\
30 \\
0 \\
0.002\end{array}$ \\
\hline
\end{tabular}

(a) Terminal kill period: male--week 60 ; female--week 61

(b) Includes moribund animals that were killed

(c) Cause of death was food deprivation.

(d) Results of the life table trend test are in the control column, and those of the life table pairwise comparisons with the controls are in the dosed columns. 

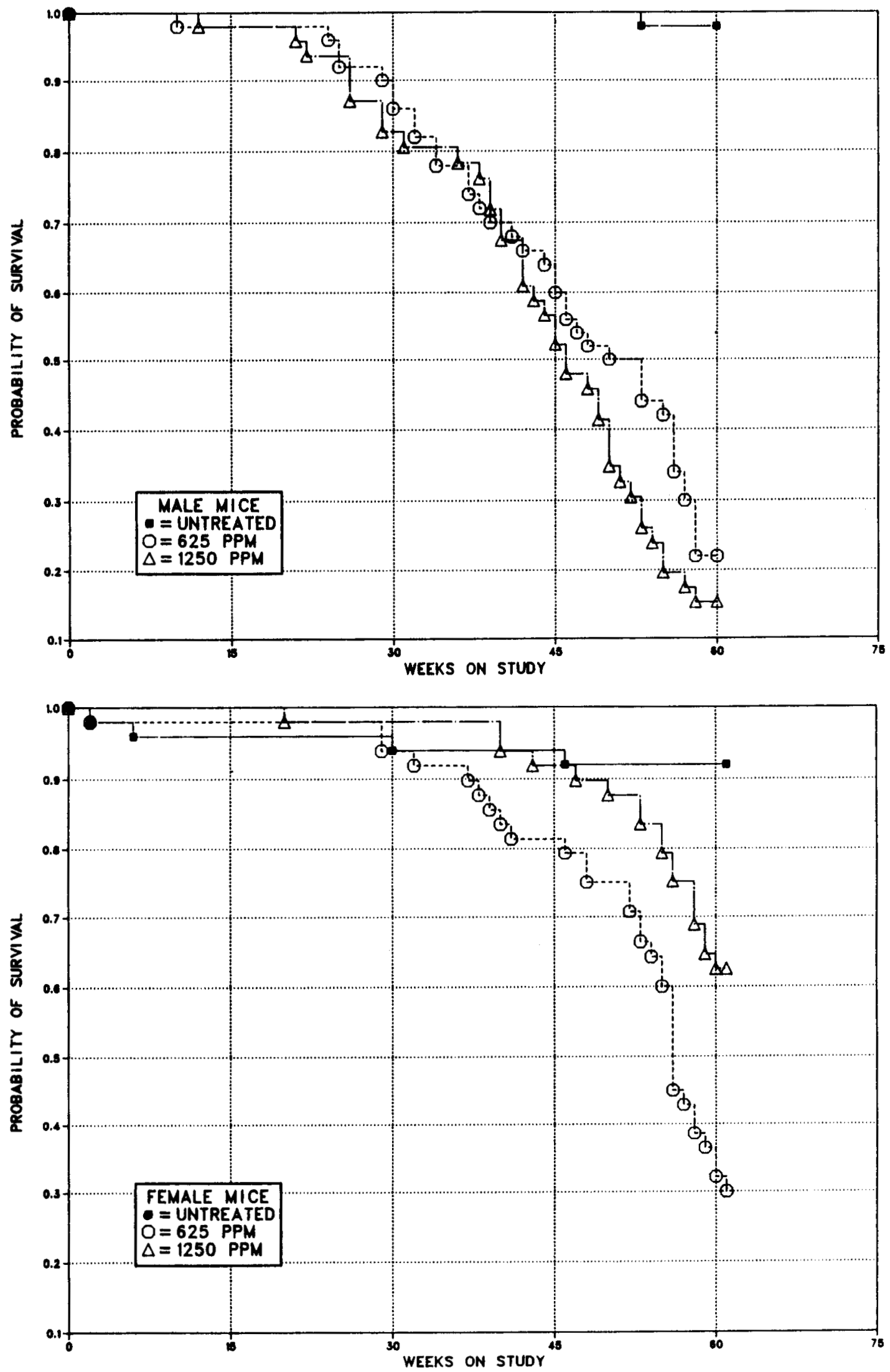

FIGURE 2. KAPLAN-MEIER SURVIVAL CURVES FOR MICE EXPOSED TO 1,3-BUTADIENE FOR SIXTY-ONE WEEKS

35

1,3-Butadiene, NTP TR 288 


\section{Pathology and Statistical Analyses of Results}

This section describes the significant or noteworthy changes in the incidence of animals with neoplastic or nonneoplastic lesions. Histopathologic findings on neoplasms in mice are summarized in Appendix A, Tables A1 and A2; Tables $A 3$ and $A 4$ give the survival and tumor status for individual male and female mice.

Findings on nonneoplastic lesions are summarized in Appendix B, Tables B1 and B2. Appen$\operatorname{dix} C$, Tables $C 1$ and $C 2$, contain the statistical analyses of those primary tumors that occurred with an incidence of at least $5 \%$ in one of the three groups. The statistical analyses used are discussed in Chapter II (Statistical Methods) and Appendix C (footnotes).

Lung: Alveolar epithelial hyperplasia was observed at increased incidences in dosed male and female mice (Table 6). Alveolar/bronchiolar adenomas, carcinomas, and adenomas or carcinomas (combined) in males and females occurred with significant positive trends; and the incidences of adenomas in dosed males and high dose females, carcinomas in high dose males and dosed females, and adenomas or carcinomas (combined) in dosed males and females were significantly higher than those in the controls. Grossly, the neoplasms protruded from the surface of the lung and were nodular in appearance. 


\begin{tabular}{|c|c|c|c|}
\hline & Control & 625 ppm & 1,250 ppm \\
\hline \multicolumn{4}{|l|}{ MALE } \\
\hline $\begin{array}{l}\text { Alveolar Epithelial Hyperplasia } \\
\text { Overall Rates }\end{array}$ & $1 / 50(2 \%)$ & $5 / 49(10 \%)$ & $2 / 49(4 \%)$ \\
\hline $\begin{array}{l}\text { Alveolar/Bronchiolar Adenoma } \\
\text { Overall Rates } \\
\text { Adjusted Rates } \\
\text { Terminal Rates } \\
\text { Life Table Tests } \\
\text { Cochran-Armitage Trend Test } \\
\text { Fisher Exact Tests }\end{array}$ & $\begin{array}{l}2 / 50(4 \%) \\
4.1 \% \\
2 / 49(4 \%) \\
P<0.001 \\
P=0.010\end{array}$ & $\begin{array}{l}12 / 49(24 \%) \\
72.3 \% \\
7 / 11(64 \%) \\
P<0.001 \\
P=0.003\end{array}$ & $\begin{array}{l}11 / 49(22 \%) \\
75.0 \% \\
4 / 7(57 \%) \\
P<0.001 \\
P=0.007\end{array}$ \\
\hline $\begin{array}{l}\text { Alveolar/Bronchiolar Carcinom } \\
\text { Overall Rates } \\
\text { Adjusted Rates } \\
\text { Terminal Rates } \\
\text { Life Table Tests } \\
\text { Cochran-Armitage Trend Test } \\
\text { Fisher Exact Tests }\end{array}$ & $\begin{array}{l}0 / 50(0 \%) \\
0.0 \% \\
0 / 49(0 \%) \\
P<0.001 \\
P=0.016\end{array}$ & $\begin{array}{l}2 / 49(4 \%) \\
18.2 \% \\
2 / 11(18 \%) \\
P=0.018 \\
P=0.242\end{array}$ & $\begin{array}{l}5 / 49(10 \%) \\
47.6 \% \\
3 / 7(43 \%) \\
P<0.001 \\
P=0.027\end{array}$ \\
\hline $\begin{array}{l}\text { Alveolar/Bronchiolar Adenoma } \\
\text { Overall Rates } \\
\text { Adjusted Rates } \\
\text { Terminal Rates } \\
\text { Life Table Tests } \\
\text { Cochran-Armitage Trend Test } \\
\text { Fisher Exact Tests }\end{array}$ & $\begin{array}{l}2 / 50(4 \%) \\
4.1 \% \\
2 / 49(4 \%) \\
P<0.001 \\
P<0.001\end{array}$ & $\begin{array}{l}14 / 49(29 \%) \\
86.2 \% \\
9 / 11(82 \%) \\
P<0.001 \\
P<0.001\end{array}$ & $\begin{array}{l}15 / 49(31 \%) \\
92.4 \% \\
6 / 7(86 \%) \\
P<0.001 \\
P<0.001\end{array}$ \\
\hline \multicolumn{4}{|l|}{ FEMALE } \\
\hline $\begin{array}{l}\text { Alveolar Epithelial Hyperplasia } \\
\text { Overall Rates }\end{array}$ & $0 / 49(0 \%)$ & $8 / 48(17 \%)$ & $7 / 49(14 \%)$ \\
\hline $\begin{array}{l}\text { Alveolar/Bronchiolar Adenoma } \\
\text { Overall Rates } \\
\text { Adjusted Rates } \\
\text { Terminal Rates } \\
\text { Life Table Tests } \\
\text { Cochran-Armitage Trend Test } \\
\text { Fisher Exact Tests }\end{array}$ & $\begin{array}{l}3 / 49(6 \%) \\
6.5 \% \\
3 / 46(7 \%) \\
P<0.001 \\
P<0.001\end{array}$ & $\begin{array}{l}9 / 48(19 \%) \\
48.1 \% \\
6 / 15(40 \%) \\
P<0.001 \\
P=0.056\end{array}$ & $\begin{array}{l}20 / 49(41 \%) \\
56.7 \% \\
15 / 30(50 \%) \\
P<0.001 \\
P<0.001\end{array}$ \\
\hline $\begin{array}{l}\text { Alveolar/Bronchiolar Carcinom } \\
\text { Overall Rates } \\
\text { Adjusted Rates } \\
\text { Terminal Rates } \\
\text { Life Table Tests } \\
\text { Cochran-Armitage Trend Test } \\
\text { Fisher Exact Tests }\end{array}$ & $\begin{array}{l}0 / 49(0 \%) \\
0.0 \% \\
0 / 46(0 \%) \\
P=0.001 \\
P=0.005\end{array}$ & $\begin{array}{l}6 / 48(13 \%) \\
36.7 \% \\
5 / 15(33 \%) \\
P<0.001 \\
P=0.012\end{array}$ & $\begin{array}{l}8 / 49(16 \%) \\
24.7 \% \\
6 / 30(20 \%) \\
P<0.001 \\
P=0.003\end{array}$ \\
\hline $\begin{array}{l}\text { Alveolar/Bronchiolar Adenoma } \\
\text { Overall Rates } \\
\text { Adjusted Rates } \\
\text { Terminal Rates } \\
\text { Life Table Tests } \\
\text { Cochran-Armitage Trend Test } \\
\text { Fisher Exact Tests }\end{array}$ & $\begin{array}{l}3 / 49(6 \%) \\
6.5 \% \\
3 / 46(7 \%) \\
P<0.001 \\
P<0.001\end{array}$ & $\begin{array}{l}12 / 48(25 \%) \\
61.7 \% \\
8 / 15(53 \%) \\
P<0.001 \\
P=0.010\end{array}$ & $\begin{array}{l}23 / 49(47 \%) \\
63.6 \% \\
17 / 30(57 \%) \\
P<0.001 \\
\\
P<0.001\end{array}$ \\
\hline
\end{tabular}

(a) The statistical analyses used are described in Chapter II (Statistical Methods) and Appendix C (footnotes). 
Hematopoietic System: Malignant lymphomas in mice of each sex occurred with significant positive trends, and the incidences in the dosed groups were significantly higher than those in the controls (Table 7). The lymphoma appeared to orginate in the thymus in most animals, although the precise origin and pathogenesis of this neoplasm is difficult to trace because of the advanced degree of development observed at the time of necropsy. In one mouse, the lymphoma was limited to the thymus, and no other tissue was involved. In one high dose animal, a lobe of the thymus which was involved by the lymphoma was completely surrounded by a mediastinal mass of lymphoma cells; the lymphoma completely obscured the architecture of the thymus, but the capsule was intact. Grossly, the tumors appeared as large, pale, firm masses (up to $2.5 \times 2.0 \times 1.5 \mathrm{~cm}$ ) in the mediastinum often accompanied by hydrothorax. Lymphomas also involved the spleen, lymph nodes, liver, lung, kidney, heart, pancreas, and stomach. The lymphomas varied from undifferentiated to moderately well differentiated; most were well-differentiated lymphocytic lymphomas composed of medium-sized lymphoid cells that formed monotonous sheets which focally or diffusely invaded multiple organs in a manner characteristic of lymphomas in mice. The malignant lymphomas were considered to be the major cause of early deaths in these studies.

TABLE 7. ANALYSIS OF HEMATOPOIETIC SYSTEM TUMORS IN MICE IN THE SIXTY-ONE-WEEK INHALATION STUDIES OF 1,3-BUTADIENE (a)

\begin{tabular}{|c|c|c|c|}
\hline & Control & 625 ppm & 1,250 ppm \\
\hline \multicolumn{4}{|l|}{ MALE } \\
\hline $\begin{array}{l}\text { Lymphoma, All Malignant } \\
\text { Overall Rates } \\
\text { Adjusted Rates } \\
\text { Terminal Rates } \\
\text { Life Table Tests } \\
\text { Cochran-Armitage Trend Test } \\
\text { Fisher Exact Tests }\end{array}$ & $\begin{array}{l}0 / 50(0 \%) \\
0.0 \% \\
0 / 49(0 \%) \\
P<0.001 \\
P<0.001\end{array}$ & $\begin{array}{l}23 / 50(46 \%) \\
59.4 \% \\
2 / 11(18 \%) \\
\mathrm{P}-0.001 \\
\mathrm{P}<0.001\end{array}$ & $\begin{array}{l}29 / 50(58 \%) \\
75.5 \% \\
1 / 7(14 \%) \\
P<0.001 \\
P<0.001\end{array}$ \\
\hline FEMALE & & & \\
\hline $\begin{array}{l}\text { Lymphoma. All Malignant } \\
\text { Overall Rates } \\
\text { Adjusted Rates } \\
\text { Terminal Rates } \\
\text { Life Table Tests } \\
\text { Cochran-Armitage Trend Test } \\
\text { Fisher Exact Tests }\end{array}$ & $\begin{array}{l}1 / 50(2 \%) \\
2.2 \% \\
1 / 46(2 \%) \\
P=0.006 \\
P=0.006\end{array}$ & $\begin{array}{l}10 / 49(20 \%) \\
32.0 \% \\
3 / 15(20 \%) \\
P<0.001 \\
P=0.003\end{array}$ & $\begin{array}{l}10 / 49(20 \%) \\
22.9 \% \\
1 / 30(3 \%) \\
P=0.003 \\
P=0.003\end{array}$ \\
\hline
\end{tabular}


Heart: Early ("preneoplastic") lesions were diagnosed as atypical endothelial hyperplasia. Atypical hyperplasia was observed at increased incidences in dosed mice of each sex (Table 8). Hemangiosarcomas in mice of each sex occurred with significant positive trends, and the incidences in the dosed groups were significantly higher than those in the controls. Grossly, the hemangiosarcomas appeared as white areas at the apex of the heart or as dark sac-like protrusions. The growth pattern as well as the close contact between proliferating endothelial cells and erythrocytes led to the diagnosis of hemangiosarcoma. The hemangiosarcomas were not confined to the heart but were also found in the liver, lung, and kidney. The lesions in these organs were regarded as metastatic because early lesions were observed only in the heart, the incidence was highest in the heart, and, with one exception, a heart hemangiosarcoma was also found in each animal having a hemangiosarcoma in the liver, lung, or kidney. The hemangiosarcomas may have caused the death of a number of animals.

Forestomach: Epithelial hyperplasia was observed at increased incidences in dosed mice of each sex (Table 9). The incidences of papillomas, of squamous cell papillomas or carcinomas (combined), and of papillomas or carcinomas (combined) in low dose male mice were significantly higher than those in the controls. The incidence of papillomas and of papillomas or carcinomas (combined) in female mice occurred with significant positive trends. Significant positive trends occurred in the incidences of all types of papillomas and of all types of papillomas or carcinomas (combined) in female mice.

Grossly, the papillomas appeared as small white nodules. The carcinomas were solid pale masses, cells of which infiltrated the walls of the stomach. In some animals, the carcinomas extended into the peritoneal cavity and invaded adjacent structures.

TABLE 8. ANALYSIS OF HEART LESIONS IN MICE IN THE SIXTY-ONE-WEEK INHALATION STUDIES OF 1,3-BUTADIENE

\begin{tabular}{|c|c|c|c|}
\hline & Control & 625 ppm & 1,250 ppm \\
\hline \multicolumn{4}{|l|}{ MALE } \\
\hline $\begin{array}{l}\text { Atypical Hyperplasia } \\
\text { Overall Rates }\end{array}$ & $0 / 50(0 \%)$ & $5 / 49(10 \%)$ & $2 / 49(4 \%)$ \\
\hline $\begin{array}{l}\text { Hemangiosarcoma } \\
\text { Overall Rates } \\
\text { Adjusted Rates } \\
\text { Terminal Rates } \\
\text { Life Table Tests } \\
\text { Cochran-Armitage Trend Test } \\
\text { Fisher Exact Tests }\end{array}$ & $\begin{array}{l}0 / 50(0 \%) \\
0.0 \% \\
0 / 49(0 \%) \\
P<0.001 \\
P=0.032\end{array}$ & $\begin{array}{l}16 / 49(33 \%) \\
57.5 \% \\
2 / 11(18 \%) \\
\mathrm{P}<0.001 \\
\mathrm{P}<0.001\end{array}$ & (a) $\begin{array}{l}7 / 49(14 \%) \\
57.3 \% \\
3 / 7(43 \%) \\
P<0.001 \\
\\
P=0.006\end{array}$ \\
\hline \multicolumn{4}{|l|}{ FEMALE } \\
\hline $\begin{array}{l}\text { Atypical Hyperplasia } \\
\text { Overall Rates }\end{array}$ & $0 / 49(0 \%)$ & $5 / 48(10 \%)$ & $8 / 49(16 \%)$ \\
\hline $\begin{array}{l}\text { Hemangiosarcoma } \\
\text { Overall Rates } \\
\text { Adjusted Rates } \\
\text { Terminal Rates } \\
\text { Life Table Tests } \\
\text { Cochran-Armitage Trend Test } \\
\text { Fisher Exact Tests }\end{array}$ & $\begin{array}{l}0 / 50(0 \%) \\
0.0 \% \\
0 / 46(0 \%) \\
P<0.001 \\
P<0.001\end{array}$ & 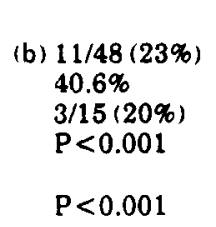 & (c) $\begin{array}{l}18 / 49(37 \%) \\
46.3 \% \\
10 / 30(33 \%) \\
\mathrm{P}<0.001 \\
\mathrm{P}<0.001\end{array}$ \\
\hline
\end{tabular}

(a) An hemangiosarcoma of the peritoneal cavity was also observed.

(b) Two hemangiosarcomas of the subcutaneous tissue were also observed.

(c) An hemangiosarcoma of the liver was also observed. 
TABLE 9. ANALYSIS OF FORESTOMACH LESIONS IN MICE IN THE SIXTY-ONE-WEEK INHALATION STUDIES OF 1,3-BUTADIENE

\begin{tabular}{|c|c|c|c|}
\hline & Control & $625 \mathrm{ppm}$ & 1,250 ppm \\
\hline \multicolumn{4}{|l|}{ MALE } \\
\hline $\begin{array}{l}\text { Epithelial Hyperplasia } \\
\text { Overall Rates }\end{array}$ & $0 / 49(0 \%)$ & $5 / 40(13 \%)$ & $7 / 44(16 \%)$ \\
\hline \multirow{2}{*}{$\begin{array}{l}\text { All Papilloma } \\
\text { Overall Rates } \\
\text { Adjusted Rates } \\
\text { Terminal Rates } \\
\text { Life Table Tests } \\
\text { Cochran-Armitage Trend Test } \\
\text { Fisher Exact Tests }\end{array}$} & \multirow{2}{*}{$\begin{array}{l}0 / 49(0 \%) \\
0.0 \% \\
0 / 48(0 \%) \\
P=0.036 \\
P=0.568\end{array}$} & $\begin{array}{l}5 / 40(13 \%) \\
45.5 \% \\
5 / 11(45 \%) \\
P<0.001\end{array}$ & $\begin{array}{l}0 / 44(0 \%) \\
0.0 \% \\
0 / 7(0 \%) \\
(a)\end{array}$ \\
\hline & & $P=0.016$ & (a) \\
\hline $\begin{array}{l}\text { Squamous Cell Carcinoma } \\
\text { Overall Rates }\end{array}$ & $0 / 49(0 \%)$ & $2 / 40(5 \%)$ & $1 / 44(2 \%)$ \\
\hline \multirow{2}{*}{$\begin{array}{l}\text { Squamous Cell Papilloma or Car } \\
\text { Overall Rates } \\
\text { Adjusted Rates } \\
\text { Terminal Rates } \\
\text { Life Table Tests } \\
\text { Cochran-Armitage Trend Test } \\
\text { Fisher Exact Tests }\end{array}$} & \multirow[t]{2}{*}{$\begin{array}{l}0 / 49(0 \%) \\
0.0 \% \\
0 / 48(0 \%) \\
P=0.032 \\
P=0.354\end{array}$} & $\begin{array}{l}4 / 40(10 \%) \\
26.2 \% \\
2 / 11(18 \%) \\
P=0.001\end{array}$ & $\begin{array}{l}1 / 44(2 \%) \\
7.1 \% \\
0 / 7(0 \%) \\
P=0.248\end{array}$ \\
\hline & & $P=0.037$ & $P=0.473$ \\
\hline \multirow{2}{*}{$\begin{array}{l}\text { All Papilloma or Carcinoma } \\
\text { Overall Rates } \\
\text { Adjusted Rates } \\
\text { Terminal Rates } \\
\text { Life Trable Tests } \\
\text { Cochran-Armitage Trend Test } \\
\text { Fisher Exact Tests }\end{array}$} & \multirow[t]{2}{*}{$\begin{array}{l}0 / 49(0 \%) \\
0.0 \% \\
0 / 48(0 \%) \\
P=0.006 \\
P=0.363\end{array}$} & $\begin{array}{l}7 / 40(18 \%) \\
50.8 \% \\
5 / 11(45 \%) \\
\mathrm{P}<0.001\end{array}$ & $\begin{array}{l}1 / 44(2 \%) \\
7.1 \% \\
0 / 70 \%) \\
P=0.248\end{array}$ \\
\hline & & $P=0.003$ & $P=0.473$ \\
\hline \multicolumn{4}{|l|}{ FEMALE } \\
\hline $\begin{array}{l}\text { Epithelial Hyperplasia } \\
\text { Overall Rates }\end{array}$ & $0 / 49(0 \%)$ & $5 / 42(12 \%)$ & $9 / 49(18 \%)$ \\
\hline \multirow{2}{*}{$\begin{array}{l}\text { Squamous Cell Papilloma } \\
\text { Overall Rates } \\
\text { Adjusted Rates } \\
\text { Terminal Rates } \\
\text { Life Table Tests } \\
\text { Cochran-Armitage Trend Test } \\
\text { Fisher Exact Tests }\end{array}$} & \multirow[t]{2}{*}{$\begin{array}{l}0 / 49(0 \%) \\
0.0 \% \\
0 / 46(0 \%) \\
P=0.248 \\
P=0.381\end{array}$} & $\begin{array}{l}3 / 42(7 \%) \\
20.0 \% \\
3 / 15(20 \%) \\
P=0.008\end{array}$ & $\begin{array}{l}1 / 49(2 \%) \\
3.3 \% \\
1 / 30(3 \%) \\
P=0.415\end{array}$ \\
\hline & & $P=0.094$ & $\mathrm{P}=0.500$ \\
\hline \multirow{2}{*}{$\begin{array}{l}\text { All papilloma } \\
\text { Overall Rates } \\
\text { Adjusted Rates } \\
\text { Terminal Rates } \\
\text { Life Table Tests } \\
\text { Cochran-Armitage Trend Test } \\
\text { Fisher Exact Tests }\end{array}$} & \multirow[t]{2}{*}{$\begin{array}{l}0 / 49(0 \%) \\
0.0 \% \\
0 / 46(0 \%) \\
P<0.001 \\
P<0.001\end{array}$} & $\begin{array}{l}4 / 42(10 \%) \\
26.7 \% \\
415(27 \%) \\
\mathrm{P}=0.001\end{array}$ & $\begin{array}{l}10 / 49(20 \%) \\
31.8 \% \\
9 / 300(30 \%) \\
P<0.001\end{array}$ \\
\hline & & $P=0.042$ & $P<0.001$ \\
\hline $\begin{array}{l}\text { Squamous Cell Carcinoma } \\
\text { Overall Rates }\end{array}$ & $0 / 49(0 \%)$ & $1 / 42(2 \%)$ & $1 / 49(2 \%)$ \\
\hline \multirow{2}{*}{$\begin{array}{l}\text { Squamous Cell Papilloma or Carcinoma } \\
\text { Overall Rates } \\
\text { Adjusted Rates } \\
\text { Terminal Rates } \\
\text { Life Table Tests } \\
\text { Cochran-Armitage Trend Test } \\
\text { Fisher Exact Tests }\end{array}$} & \multirow{2}{*}{$\begin{array}{l}0 / 49(0 \%) \\
0.0 \% \\
0 / 46(0 \%) \\
P=0.249 \\
P=0.393\end{array}$} & $\begin{array}{l}4 / 42(10 \%) \\
22.9 \% \\
3 / 15(20 \%) \\
P=0.003\end{array}$ & $\begin{array}{l}1 / 49(2 \%) \\
3.4 \% \\
1 / 29(3 \%) \\
P=0.408\end{array}$ \\
\hline & & $P=0.042$ & $\mathrm{P}=0.500$ \\
\hline \multirow{2}{*}{$\begin{array}{l}\text { All Papilloma or Carcinoma } \\
\text { Overall Rates } \\
\text { Adjusted Rates } \\
\text { Terminal Rates } \\
\text { Life Table Tests } \\
\text { Cochran-Armitage Trend Test } \\
\text { Fisher Exact Tests }\end{array}$} & \multirow[t]{2}{*}{$\begin{array}{l}0 / 49(0 \%) \\
0.0 \% \\
0 / 46(0 \%) \\
P<0.001 \\
P<0.001\end{array}$} & $\begin{array}{l}5 / 42(12 \%) \\
29.3 \% \\
415(27 \%) \\
\mathrm{P}<0.001\end{array}$ & $\begin{array}{l}10 / 49(20 \%) \\
31.8 \% \\
9 / 30(30 \%) \\
\mathrm{P}<0.001\end{array}$ \\
\hline & & $P=0.018$ & $P<0.001$ \\
\hline
\end{tabular}

(a) No P value is presented because no tumors were observed in the 1,250-ppm and control groups. 
Liver: Necrosis was observed at increased incidences in dosed male and low dose female mice (male: control, 1/50, 2\%; low dose, $8 / 49,16 \%$; high dose, $8 / 49,16 \%$; female: $6 / 50,12 \%$; $15 / 47$, $32 \% ; 6 / 49,12 \%$ ). Hepatocellular adenomas and hepatocellular adenomas or carcinomas (combined) in female mice occurred with significant positive trends (Table 10). The incidence of he- patocellular adenomas or carcinomas (combined) in high dose female mice was significantly higher than that in the controls. The carcinomas were found in one low dose and one high dose female. In male mice, hepatocellular adenomas or carcinomas (combined) were observed in $8 / 50$ $(16 \%)$ of the controls, $6 / 49(12 \%)$ of the low dose group, and $2 / 49$ ( $4 \%$ ) of the high dose group.

TABLE 10. ANALYSIS OF LIVER TUMORS IN FEMALE MICE IN THE SIXTY-ONE-WEEK INHALATION STUDY OF 1,3-BUTADIENE

\begin{tabular}{|c|c|c|c|}
\hline & Control & $625 \mathrm{ppm}$ & $1,250 \mathrm{ppm}$ \\
\hline $\begin{array}{l}\text { Hepatocellular Adenoma } \\
\text { Overall Rates } \\
\text { Adjusted Rates } \\
\text { Terminal Rates } \\
\text { Life Table Tests } \\
\text { Cochran-Armitage Trend Test } \\
\text { Fisher Exact Tests }\end{array}$ & $\begin{array}{l}0 / 50(0 \%) \\
0.0 \% \\
0 / 46(0 \%) \\
P=0.015 \\
P=0.025\end{array}$ & $\begin{array}{l}1 / 47(2 \%) \\
6.7 \% \\
1 / 15(7 \%) \\
P=0.278 \\
P=0.485\end{array}$ & $\begin{array}{l}4 / 49(8 \%) \\
12.1 \% \\
3 / 30(10 \%) \\
P=0.030 \\
P=0.056\end{array}$ \\
\hline $\begin{array}{l}\text { Hepatocellular Carcinoma } \\
\text { Overall Rates }\end{array}$ & $0 / 50(0 \%)$ & $1 / 47(2 \%)$ & $1 / 49(2 \%)$ \\
\hline $\begin{array}{l}\text { Hepatocellular Adenoma or Car } \\
\text { Overall Rates } \\
\text { Adjusted Rates } \\
\text { Terminal Rates } \\
\text { Life Table Tests } \\
\text { Cochran-Armitage Trend Test } \\
\text { Fisher Exact Tests }\end{array}$ & $\begin{array}{l}0 / 50(0 \%) \\
0.0 \% \\
0 / 46(0 \%) \\
P=0.009 \\
P=0.016\end{array}$ & $\begin{array}{l}2 / 47(4 \%) \\
13.3 \% \\
2 / 15(13 \%) \\
P=0.048 \\
P=0.232\end{array}$ & $\begin{array}{l}5 / 49(10 \%) \\
14.3 \% \\
3 / 30(10 \%) \\
P=0.015 \\
P=0.027\end{array}$ \\
\hline
\end{tabular}




\section{RESULTS}

Mammary Gland: Acinar cell carcinomas in female mice occurred with a significant positive trend, and the incidences in the dosed groups were significantly higher than that in the controls (Table 11). The acinar cell carcinomas metastasized to the lung in one low dose and one high dose female. Four adenosquamous carcinomas were found in low dose female mice. Adenosquamous carcinomas metastasized to the lung in three low dose females.

TABLE 11. ANALYSIS OF MAMMARY GLAND LESIONS IN FEMALE MICE IN THE SIXTY.ONE. WEEK INHALATION STUDY OF 1,3-BUTADIENE

\begin{tabular}{|c|c|c|c|}
\hline & Control & 625 ppm & 1,250 ppm \\
\hline $\begin{array}{c}\text { Hyperplasia, NOS } \\
\text { Overall Rates }\end{array}$ & $5 / 50(10 \%)$ & $2 / 49(4 \%)$ & $0 / 49(0 \%)$ \\
\hline $\begin{array}{l}\text { Acinar Cell Carcinoma } \\
\text { Overall Rates } \\
\text { Adjusted Rates } \\
\text { Terminal Rates } \\
\text { Life Table Tests } \\
\text { Cochran-Armitage Trend Test } \\
\text { Fisher Exact Tests }\end{array}$ & $\begin{array}{l}0 / 50(0 \%) \\
0.0 \% \\
0 / 46(0 \%) \\
P=0.004 \\
P=0.007\end{array}$ & $\begin{array}{l}2 / 49(4 \%) \\
13.3 \% \\
2 / 15(13 \%) \\
P=0.048 \\
P=0.242\end{array}$ & $\begin{array}{l}6 / 49(12 \%) \\
16.7 \% \\
3 / 30(10 \%) \\
P=0.007 \\
P=0.012\end{array}$ \\
\hline $\begin{array}{l}\text { Adenosquamous Carcinoma } \\
\text { Overall Rates } \\
\text { Adjusted Rates } \\
\text { Terminal Rates } \\
\text { Life Table Tests } \\
\text { Cochran-Armitage Trend Test } \\
\text { Fisher Exact Tests }\end{array}$ & $\begin{array}{l}0 / 50(0 \%) \\
0.0 \% \\
0 / 46(0 \%) \\
P=0.575 \\
P=0.615\end{array}$ & $\begin{array}{l}4 / 49(8 \%) \\
11.9 \% \\
0 / 15(0 \%) \\
P=0.030 \\
P=0.056\end{array}$ & $\begin{array}{l}0 / 49(0 \%) \\
0.0 \% \\
0 / 30(0 \%) \\
\text { (a) } \\
\text { (a) }\end{array}$ \\
\hline
\end{tabular}

(a) No $\mathrm{P}$ value is presented because no tumors were observed in the 1,250-ppm and control groups. 
Ovary: The incidences of ovarian lesions in female mice are presented in Table 12. Epithelial hyperplasia refers to a proliferation of tubular structures and is usually the early stage of a tubular adenoma. Lesions that showed a tubular cell component as well as a granulosa cell component were diagnosed as "mixed tumor, benign." Granulosa cell tumors occurred with significant positive trends, and the incidences in the dosed groups were significantly higher than that in the controls (Table 13).

Uterus: Involution of the uterus, characterized by fewer and less prominent endometrial glands, was observed at increased incidence in dosed female mice (control, 0/49; low dose, 7/46, 15\%; high dose, 14/49, 29\%).

TABLE 12. NUMBERS OF FEMALE MICE WTTH NEOPLASTIC AND NONNEOPLASTIC LESIONS IN THE OVARY IN THE SIXTY-ONE.WEEK INHALATION STUDY OF 1,3-BUTADIENE

\begin{tabular}{|c|c|c|c|}
\hline & Control & 625 ppm & 1,250 ppm \\
\hline No. of mice examined & 49 & 45 & 48 \\
\hline \multicolumn{4}{|l|}{ Lesion } \\
\hline $\begin{array}{l}\text { Granulosa cell tumor } \\
\text { Granulosa cell carcinoma } \\
\text { Granulosa cell tumor or carcinoma } \\
\text { Tubular adenoma } \\
\text { Benign mixed tumor } \\
\text { Cystadenoma } \\
\text { Granulosa cell hyperplasia } \\
\text { Epithelial hyperplasia } \\
\text { Atrophy }\end{array}$ & $\begin{array}{l}0 \\
0 \\
0 \\
0 \\
0 \\
0 \\
0 \\
0 \\
2\end{array}$ & $\begin{array}{r}6 \\
0 \\
6 \\
2 \\
0 \\
1 \\
2 \\
3 \\
40\end{array}$ & $\begin{array}{r}12 \\
1 \\
13 \\
0 \\
2 \\
0 \\
0 \\
0 \\
40\end{array}$ \\
\hline
\end{tabular}

TABLE 13. ANALYSIS OF OVARIAN TUMORS IN FEMALE MICE IN THE SIXTY-ONE.WEEK INHALATION STUDY OF 1,3-BUTADIENE

\begin{tabular}{llll}
\hline & Control & $\mathbf{6 2 5} \mathbf{p p m}$ & $1,250 \mathbf{p p m}$ \\
\hline Granulosa Cell Tumor & & & \\
Overall Rates & $0 / 49(0 \%)$ & $6 / 45(13 \%)$ & $12 / 48(25 \%)$ \\
Adjusted Rates & $0.0 \%$ & $33.4 \%$ & $36.6 \%$ \\
Terminal Rates & $0 / 46(0 \%)$ & $4 / 15(27 \%)$ & $9 / 29(31 \%)$ \\
Life Table Tests & $\mathrm{P}<0.001$ & $\mathrm{P}<0.001$ & $\mathrm{P}<0.001$ \\
Cochran-Armitage Trend Test & $\mathrm{P}<0.001$ & $\mathrm{P}=0.010$ & $\mathrm{P}<0.001$ \\
Fisher Exact Tests & & & \\
\hline
\end{tabular}


Nasal Cavity: Inflammation, fibrosis, osseous and cartilaginous metaplasia, and atrophy of the olfactory epithelium were observed in the region of the ethmoturbinates at increased incidences in high dose male mice (Table 14). No neoplastic lesions were observed at any concentration.

Preputial Gland: Carcinomas were observed at an increased incidence in dosed male mice (control, 0/50; low dose, 3/50,6\%; high dose, $2 / 50,4 \%)$.

Brain: Gliomas were found in the brains of one high dose and two low dose male mice. An ependymoma was found in the brain of one low dose male mouse.

Zymbal Gland: Carcinomas were observed in two high dose male mice and one high dose female mouse.

Testis: Testicular atrophy was observed at an increased incidence in dosed male mice (control, $0 / 50$; low dose, 19/47, 40\%; high dose, $11 / 48,23 \%)$.

TABLE 14. NUMBERS OF MICE WITH NONNEOPLASTIC LESIONS OF THE NASAL CAVITY IN THE SIXTY.ONE.WEEK INHALATION STUDIES OF 1,3-BUTADIENE

\begin{tabular}{|c|c|c|c|}
\hline & Control & 625 ppm & 1,250 ppm \\
\hline \multicolumn{4}{|l|}{ MALE } \\
\hline No. of mice examined & 50 & 50 & 50 \\
\hline \multicolumn{4}{|l|}{ Lesion } \\
\hline $\begin{array}{l}\text { Chronic inflammation } \\
\text { Fibrosis } \\
\text { Cartilaginous metaplasia } \\
\text { Osseous metaplasia } \\
\text { Atrophy of olfactory sensory epithelium }\end{array}$ & $\begin{array}{l}0 \\
0 \\
0 \\
0 \\
0\end{array}$ & $\begin{array}{l}0 \\
0 \\
0 \\
0 \\
0\end{array}$ & $\begin{array}{l}35 \\
35 \\
16 \\
11 \\
32\end{array}$ \\
\hline \multicolumn{4}{|l|}{ FEMALE } \\
\hline No. of mice examined & 50 & 49 & 49 \\
\hline \multicolumn{4}{|l|}{ Lesion } \\
\hline $\begin{array}{l}\text { Chronic inflammation } \\
\text { Fibrosis } \\
\text { Cartilaginous metaplasia } \\
\text { Osseous metaplasia } \\
\text { Atrophy of olfactory sensory epithelium }\end{array}$ & $\begin{array}{l}0 \\
0 \\
0 \\
0 \\
0\end{array}$ & $\begin{array}{l}0 \\
0 \\
0 \\
0 \\
0\end{array}$ & $\begin{array}{l}2 \\
2 \\
1 \\
2 \\
0\end{array}$ \\
\hline
\end{tabular}




\section{DISCUSSION AND CONCLUSIONS}


Male and female $\mathrm{B}_{6} \mathrm{C}_{3} \mathrm{~F}_{1}$ mice in 15-day and 14week studies were exposed to air containing 1,3butadiene at concentrations of $0-8,000 \mathrm{ppm}$. In the 15-day studies, survival was unaffected by dose and no pathologic effects were observed; mean body weight gain decreased slightly at the high concentrations. In the 14-week studies, mean body weight gain decreased with dose, and survival in the 5,000-ppm and 8,000-ppm groups of males was markedly reduced; no other compound-related effects were observed. Concentrations for the long-term studies were set at 0,625 , or $1,250 \mathrm{ppm}$. The doses used in the mouse studies conducted for the NTP were about onesixth (high dose) and five-eighths (low dose) those used in the rat studies $(0,1,000$, or 8,000 ppm) done by the Hazleton Labs Europe (1981); the duration of the mouse studies was approximately one-half that of the rat studies.

In the long-term studies of mice, increased mortality was apparent in groups of dosed males at week 22 and females at week 30 . These studies were terminated at week 60 for males and week 61 for females because survival in dosed groups was reduced (male: control, 49/50; low dose, 11/50; high dose, 7/50; female: $46 / 50 ; 15 / 50$; $30 / 50$ ). Mean body weights of exposed mice were not significantly different from those of the controls. In spite of the shortened survival (mice lived to be 68-70 weeks old instead of 108-110 weeks of age in a 2-year study), significantly increased incidences of mesenchymal and epithelial neoplasms were observed at multiple sites. Neoplasms occurred in 1,3-butadiene-exposed mice at increased incidences in the lung, hematopoietic system, heart, and stomach in males and females and in the ovary, mammary gland (carcinomas), and liver in females. In the rat studies, compound-related neoplasms occurred in the pancreas and testes in males and in the uterus and mammary gland (fibroadenomas) in females (Hazleton Labs Europe, 1981). Neoplasms of the Zymbal gland and brain (glioma) were observed in both studies (Table 15). Brain neoplasms have not been found in 2,343 untreated male $\mathrm{B} \mathrm{CC}_{3} \mathrm{~F}_{1}$ mice in 2-year studies in the NTP Program. Zymbal gland neoplasms have been diagnosed in 1/2,343 untreated male $B 6 C 3 F_{1}$ mice and in $0 / 2,486$ untreated female $\mathrm{B} \mathrm{C} 3 \mathrm{~F}_{1}$ mice in the NTP Program.
The decreased survival of mice exposed to 1,3butadiene in these studies differed markedly from the survival of Sprague-Dawley rats exposed to the chemical at higher concentrations for 105-111 weeks (Hazleton Labs Europe, 1981). Twenty percent of the rats exposed at 1,000 or $8,000 \mathrm{ppm}$ survived until week 111 . In the studies in mice, the early deaths were considered to be due primarily to malignant tumors, including lymphomas and hemangiosarcomas involving multiple organs. Overall tumor incidences in these 61 -week studies were $20 \%$ and $12 \%$ in concurrent controls as compared with a range of $80 \%-94 \%$ in exposed mice (male: $10 / 50$; $44 / 50 ; 40 / 50$; female: $6 / 50 ; 40 / 49 ; 46 / 49$ ).

Toxic and proliferative lesions of the nasal cavity occurred at increased incidences in the high dose groups: chronic inflammation, fibrosis, cartilaginous metaplasia, and osseous metaplasia were found in males and females, and atrophy of the olfactory sensory epithelium was seen in male but not female mice. In Sprague-Dawley rats exposed to 1,3-butadiene at $8,000 \mathrm{ppm}$ for 105-111 weeks, focal alveolar epithelialization in the respiratory tract was observed; investigators in that study did not consider the effect to be compound related (Hazleton Labs Europe, 1981). In humans, mucosal changes in the upper respiratory tract (which altered sensory perception), laryngotracheitis, and bronchitis were reported in workers in the synthetic rubber industry in Eastern Europe (Gunter and Lucas, 1973; Ripp, 1968; Volkova and Bagdinov, 1969; Faustov, 1972).

Alveolar/bronchiolar adenomas or carcinomas (combined) occurred at significantly increased incidences in dosed mice of each sex (male: $2 / 50$; $14 / 49 ; 15 / 49$; female: $3 / 49 ; 12 / 48 ; 23 / 49$ ). Compound-related neoplasms were not found in the lungs of the Sprague-Dawley rats exposed at a higher concentration for a longer period of time.

Malignant lymphomas occurred at various sites in male and female mice at increased incidences and were considered to be the primary cause of early deaths. These lesions were found in 21/39 low dose and 28/43 high dose males and in $7 / 34$ low dose and $9 / 19$ high dose females that died or were killed before week 60 . Lymphomas were 
TABLE 15. SIGNIFICANT EFFECTS OF EXPOSURE TO 1,3-BUTADIENE ON SPRAGUE-DAWLEY RATS AND B6C3F 1 MICE IN INHALATION STUDIES

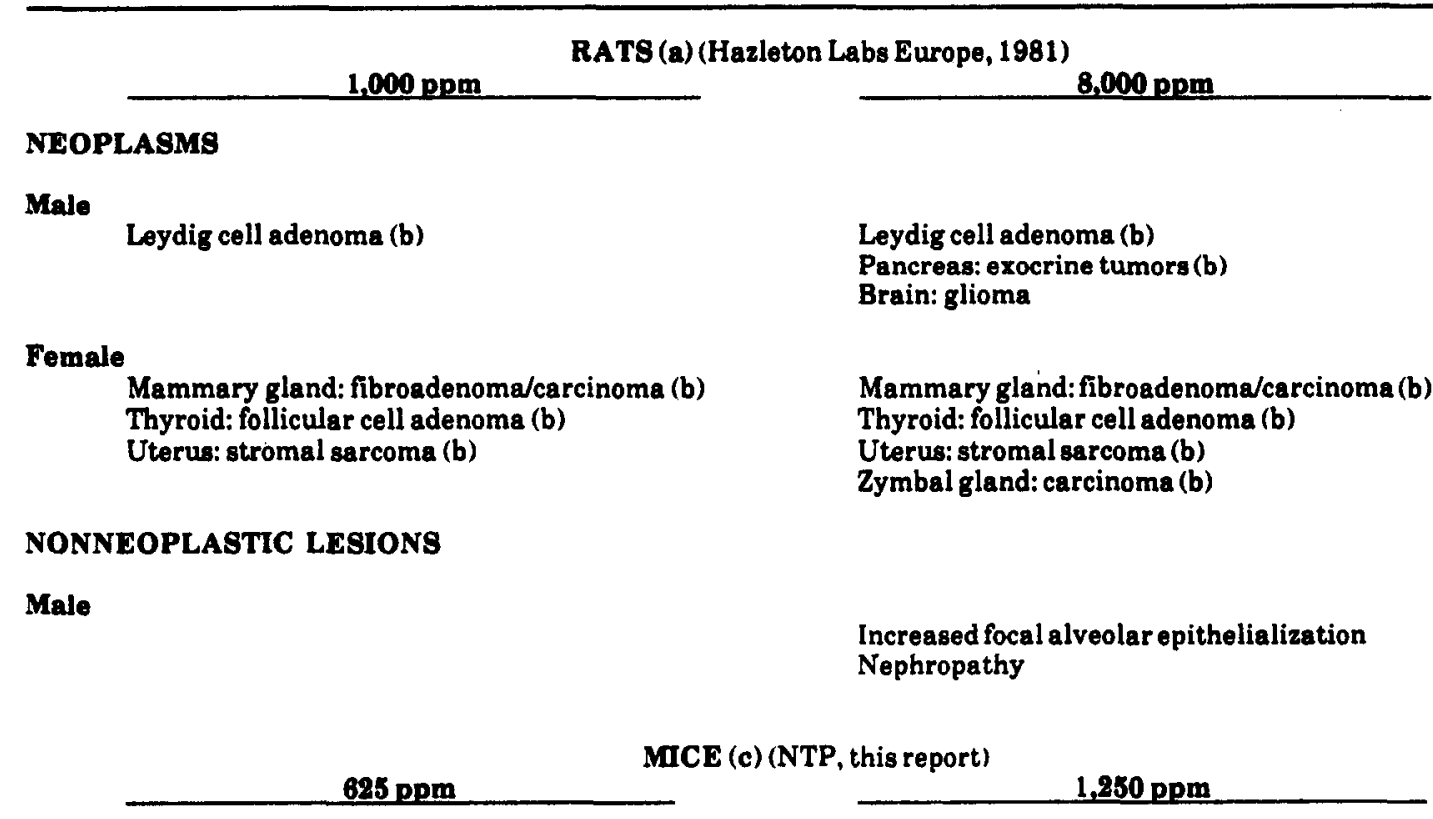

\section{NEOPLASMS}

Male

\author{
Heart: hemangiosarcoma (b) \\ Malignant lymphoma (b) \\ Lung: alveolar/bronchiolar adenoma and carcinoma (b) \\ Forestomach: papilloma (b) \\ Preputial gland: squamous cell carcinoma (d) \\ Brain: glioma (d)
}

Female

Heart: hemangiosarcoma (b)

Malignant lymphoma (b)

Lung: alveolar/bronchiolar adenoma and carcinoma (b)

Forestomach: papilloma (b)

Ovary: granulosa cell tumor (b)

\section{NONNEOPLASTIC LESIONS}

Male

Forestomach: epithelial hy perplasia (b)

Liver necrosis (b)

Testicular atrophy (b)

Female

Liver necrosis (b)

Forestomach: epithelial hyperplasia (b)

Ovary: atrophy (b)

Uterus: involution (b)
Heart: hemangiosarcoma (b)

Malignant lymphoma (b)

Lung: alveolar/bronchiolar adenoma and carcinoma (b)

Preputial gland: squamous cell carcinoma (d)

Zymbal gland: carcinoma (d)

Brain: glioma (d)

Heart: hemangiosarcoma (b)

Malignent lymphoma (b)

Lung: alveolar/bronchiolar adenoma and carcinoma (b)

Forestomach: papilloma (b)

Mammary gland: acinar cell carcinoma (b)

Ovary: granulosa cell tumor (b)

Liver: hepatocellular adenoma or carcinoma (combined)(b)

Forestomach: epithelial hyperplasia (b)

Liver necrosis (b)

Nasal cavity lesions (chronic inflammation, fibrosis, cartilaginous metaplasia, osseous metaplasia, atrophy of sensory epithelium (b)

Testicular atrophy (b)

Forestomach: epithelial hyperplasia (b)

Ovary: atrophy (b)

Uterus: involution (b)

(a) Groups of 100 male and female Sprague-Dawley rats were exposed to air containing $0,1,000$, or 8,000 ppm 1,3-butadiene $6 \mathrm{~h} / \mathrm{d}, 6 \mathrm{~d} / \mathrm{wk}$ for $105 \mathrm{wk}$ (female), or $111 \mathrm{wk}$ (male); survival in dosed groups decreased.

(b) Statistically significant $(P<0.05)$

(c) Groups of 50 male and female B6C3F 1 mice were exposed to air containing 0,625, or 1,250 ppm 1,3-butadiene $6 \mathrm{~h} / \mathrm{d}, 5 \mathrm{~d} / \mathrm{wk}$

for $60 \mathrm{wk}$ (male), or $61 \mathrm{wk}$ (female); survival in dosed groups decreased and was the reason for early termination.

(d) Considered uncommon at $60 \mathrm{wk}$ 
observed as early as week 20 in a high dose female; most of the deaths attributed to this tumor occurred between weeks 40 and 45 . Increased incidences of lymphomas were not observed in the Hazleton rat study.

The incidences of hemangiosarcoma of the heart were increased in dosed male and female mice after the animals had been on test for only 60-61 weeks. The heart lesions were striking in that a spectrum of changes was observed: changes varied from the presence of more prominent endothelial cells (diagnosed as atypical hyperplasia) to frank tumor masses. Hemangiomas and hemangiosarcomas of the heart are rare tumors; only $1 / 2,372$ and $1 / 2,372$ have been observed in untreated male and $0 / 2,443$ and $1 / 2,443$ in untreated female $\mathrm{B}_{6} \mathrm{C}_{3} \mathrm{~F}_{1}$ mice in 2 year studies in the NTP Carcinogenesis Program. These heart lesions were not observed in the Sprague-Dawley rats.

Although increased incidences of necrosis of the liver were associated with exposure to 1,3-butadiene in male and female mice (male: $1 / 50,8 / 49$, 8/49; female: $6 / 50,15 / 47,6 / 49$ ), a decreased incidence of hepatocellular neoplasms was observed in dosed male mice. The increased incidence of hepatocellular adenomas or carcinomas (com. bined) $(0 / 50,2 / 47,5 / 49)$ in dosed female mice, however, was considered to be due to exposure to 1,3-butadiene, largely because of the short latency period. Increased incidences of hepatocellular neoplasms were not observed in rats in the Hazleton study (Hazleton Labs Europe, 1981).

Epithelial hyperplasia of the forestomach in male and female mice and papillomas or carcinomas of the forestomach in males occurred at significantly increased incidences. Although unlikely, these lesions could have resulted from ingesting the test chemical when the mice licked their fur or from swallowing the chemical during exposure. These lesions were not increased in Sprague-Dawley rats.

Testicular and ovarian atrophy and uterine involution observed in mice were associated with exposure to 1,3-butadiene. Testicular or Leydig cell tumors were reported in the long-term inhalation studies in Sprague-Dawley rats (Hazleton Labs Europe, 1981), but they were not seen in the 60-61-week studies in mice. The testicular atrophy $(0 / 50,19 / 47,11 / 48)$, ovarian atrophy $(2 / 49,40 / 45,40 / 48)$, and uterine involution $(0 / 49,7 / 46,14 / 49)$ observed in exposed mice were not seen in the rat studies. The morphology of the uterine epithelium changed from hyperplastic endometrial epithelium in the controls to a less active involuted appearance in some of the low dose and high dose animals. The involuted uteri were characterized by fewer and less prominent endometrial glands. The observed uterine involution is considered to be secondary to ovarian atrophy. In dosed female mice, granulosa cell tumors of the ovary and acinar cell carcinomas of the mammary gland were seen at increased incidences. Tumors of the ovary were not seen at increased incidences in the Hazleton inhalation study conducted with Sprague-Dawley rats; however, those rats had increased incidences of acinar cell tumors of the mammary gland (females) and Leydig cell tumors of the testes. Follicular cell adenomas of the thyroid gland were seen in only one control male and one low dose female mouse, although the thyroid was one of the primary sites affected in Sprague-Dawley rats (Hazleton Labs Europe, 1981).

Several types of neoplasms occurred in dosed mice at incidences that were marginally increased relative to those of the controls: squamous cell carcinomas of the preputial gland in low dose males, gliomas of the brain in two low dose males and one high dose male, carcinomas of the Zymbal gland in two high dose males and one high dose female, and adenosquamous carcinomas of the mammary gland in four low dose females (three metastasized to the lungs). Brain and Zymbal gland neoplasms were also noted in the study of Sprague-Dawley rats (Hazleton Labs Europe, 1981).

The results of these two carcinogenesis studies in rodents strongly suggest that $\mathrm{B} 6 \mathrm{C} 3 \mathrm{~F}_{1}$ mice are more susceptible to the carcinogenic effects of 1,3-butadiene than are Sprague-Dawley rats. Comparative tissue-disposition studies in Sprague-Dawley rats and $B 6 \mathrm{C}_{3} \mathrm{~F}_{1}$ mice are being conducted by NTP. Additional metabolism studies (F344/N vs Sprague-Dawley rats, males vs females) are scheduled by NTP.

In vitro tests indicate that the mutagenic form of 1,3-butadiene is one or more volatile oxidative metabolites that are base-pair substitution 
mutagens. Although in vivo tests have not determined the chemical's metsbolic pathways, the observed carcinogenicity of 1,3-butadiene may be due to the formation of such metabolites. The epoxy derivatives diepoxybutane, 1,2-epoxybutane, 2,3-epoxybutane, and 3,4-epoxybutene have been shown to be mutagenic in a variety of test systems.

Diepoxybutane has been shown to be mutagenic in bacteria (McCann et al., 1975; Voogd et al., 1981), yeast (Olszewska and Kilbey, 1975), Neurospora (Ong and de Serres, 1975), Drosophila (Sankaranarayanan, 1983), and mammalian cells (NTP, unpublished results). Diepoxybutane also has been shown to cause sister-chromatid exchanges in the mouse in vivo (Conner et al., 1983) and transformation of mammalian cells in vitro (Pienta, 1980). 1,2-Epoxybutane has been shown to be mutagenic in bacteria (McCann et al., 1975; Voogd et al., 1981), yeast (Migliore et al., 1982), Neurospora (Kolmark and Giles, 1955), Drosophila (Knaap et al., 1982), and mammalian cells (Amacher et al., 1980). It also has been shown to transform mammalian cells in vitro (Pienta, 1980). 2,3Epoxybutane has been shown to be mutagenic in bacteria (Voogd et al., 1981), yeast (Migliore et al., 1982), and Neurospora (Kolmark and Giles, 1955). 3,4-Epoxybutene has been shown to be mutagenic in bacteria (Voogd et al., 1981). The mutagenic potency of the four epoxides was compared in only one study (Voogd et al., 1981), and the results in bacteria showed that the diepoxide was more potent than the monoepoxides.

Several of the epoxides of 1,3-butadiene were tested for carcinogenicity by subcutaneous injection in mice (Van Duuren, 1969). Although the duration, number of animals and controls used, and overall description of the studies are inadequate for a full carcinogenesis evaluation, the results indicated that 3,4-epoxybutene and both isomers of diepoxybutane were carcinogenic under the conditions of the study. In addition, the diepoxides appeared to be more potent than the monoepoxides, a finding in agreement with the mutagenic potencies of these epoxides in bacteria. Although the diepoxides are the most potent mutagenic/carcinogenic forms of the parent compound, further studies (e.g., metabolism, tissue distribution, kinetics) would assist in identifying which metabolite or combination of metabolites may be associated with the observed carcinogenic activity of 1,3-butadiene. 4-Vinyl-1-cyclohexene, the dimer of 1,2butadiene, is currently on test in the NTP Carcinogenesis Program.

Conclusions: Under the conditions of these studies, there was clear evidence of carcinogenicity* for 1,3-butadiene in male and female $\mathrm{B} 6 \mathrm{C} 3 \mathrm{~F}_{1}$ mice, as shown by increased incidences and early induction of hemangiosarcomas of the heart, malignant lymphomas, alveolar/bronchiolar adenomas and carcinomas, and papillomas of the stomach in males and females; and of acinar cell carcinomas of the mammary gland, granulosa cell tumors of the ovary, and hepatocellular adenomas and adenomas or carcinomas (combined) in females. 1,3-Butadiene was associated with nonneoplastic lesions in the respiratory epithelium, liver necrosis, and testicular or ovarian atrophy.

"Categories of evidence of carcinogenicity are defined in the Note to the Reader on page 2. 


\section{REFERENCES}


1. Abdullaeva, R. (1973) Disease rate of synthetic rubber plant personnel (according to clinical data for 10 years). Tr. Azerb, Nauchno-Issled. Inst. Grig. Tr. Prof. Zabol 8:140-144. Cited in Parsons, T.; Wilkins, G. (1976) Biological Effects and Environmental Aspects of 1,3-Butadiene. USEPA Contract No. 68-01-3249. NTIS PB No. 253982.

2. Alekperov, I.; Vinokurova, M.; Knabengof, V. (1970) Combined effect of styrene, butadiene, and ethyl benzene on the contractile function of the myocardium. Cited in Parsons, T.; Wilkins, G. (1976) Biological Effects and Environmental Aspects of 1,3-Butadiene. USEPA Contract No. 68-01-3249. NTIS PB No. 253982.

3. Amacher, D.; Paillet, S.; Turner, G.; Ray, V.; Salsburg, D. (1980) Point mutations at the thymidine kinase locus in L5178Y mouse lymphoma cells. II. Test validation and interpretation. Mutat. Res. 72:447-474.

4. American Conference of Governmental Industrial Hygienists (ACGIH) (1981) TLVs--Threshold Limit Values for Chemical Substances and Physical Agents in the Workroom Environment with Intended Changes for 1981. Cincinnati, $\mathrm{OH}$ : ACGIH. $94 \mathrm{p}$.

5. Armitage, P. (1971) Statistical Methods in Medical Research. New York: John Wiley \& Sons, Inc., pp. 362-365.

6. Batkina, I. (1976) Maximum permissible concentrations of divinyl vapors in the air of work areas. Gig. Sanit. 31(12):18-22. Cited in Parsons, T.: Wilkins, G. (1976) Biological Effects and Environmental Aspects of 1,3-Butadiene. USEPA Contract No. 68-01-3249. NTIS PB No. 253982.

7. Berenblum, I., Ed. (1969) Carcinogenicity Testing: A Report of the Panel on Carcinogenicity of the Cancer Research Commission of UICC, Vol. 2. Geneva: International Union Against Cancer.

8. Boorman, G.; Montgomery, C., Jr.; Hardisty, J.; Eustis, S.; Wolfe, M., McConnell, E. (In Press): Quality assurance in pathology for rodent toxicology and carcinogenicity tests. Milman; Weisburger, Eds.: Handbook of Carcinogen Testing.
9. Carpenter, C.; Shaffer, C.; Weil, C.; Smyth, H. (1944) Studies on the inhalation of 1,3-butadiene; with a comparison of its narcotic effect with benzol, toluol, and styrene, and a note on the elimination of styrene by the human. J. Ind. Hyg. Tox. 26:69-78.

10. Chemical \& Engineering News (1983) Production by the U.S. chemical industry. June 13, pp. 29-33.

11. Chemical \& Engineering News (1984) C\&E's top 50 chemical products and producers. May 7 , p. 9.

12. Conner, M.; Luo, J.; Gutierrez de Gotera, $O$. (1983) Induction and rapid repair of sister-chromatid exchanges in multiple murine tissues in vivo by diepoxybutane. Mutat. Res. 108:251263.

13. Cox, D. (1972) Regression models and life tables. J. R. Stat. Soc. B34:187-220.

14. Crouch, C.; Pullinger, D.; Gaunt, İ. (1979) Inhalation toxicity studies with 1,3-butadiene-2. 3 month toxicity study in rats. Am. Ind. Hyg. Assoc. J. 40:796-802.

15. Cyashenko, K.; Sidenko, A. (1976) Improvement of working conditions in the manufacturing of dimethyl terephthalate. Gig. Tr. Prof. Zabol. 9:42-43. Cited in Parsons, T.; Wilkins, G. (1976) Biological Effects and Environmental Aspects of 1,3-Butadiene. USEPA Contract No. 68-01- 3249. NTIS PB No. 253982.

16. de Meester, C.; Poncelet, F.; Roberfroid, M.; Mercier, M. (1978) Mutagenicity of butadiene and butadiene monoxide. Biochem. Biophys. Res. Commun. 80:298-305.

17. de Meester, C.; Poncelet, F.; Roberfroid, M.; Mercier, M. (1980) The mutagenicity of butadiene towards Salmonella typhimurium. Toxicol Lett. 6:125-130.

18. D'Yachkov, V. (1972) Evaluation of air pollution due to emissions. Tr. Kuibyshev. Nauch. Issled. Inst. Gig. 7:94-96. Cited in Parsons, T.; Wilkins, G. (1976) Biological Effects and Environmental Aspects of 1,3-Butadiene. USEPA Contract No. 68-01-3249. NTIS PB No. 253982. 
19. Faustov, A. (1972) Toxic conditions in the production of synthetic rubbers. Tr. Voromezh. Med. Inst. 87(10-16). Cited in Parsons, T.; Wilkins, G. (1976) Biological Effects and Environmental Aspects of 1,3-Butadiene. USEPA Contract No. 68-01-3249. NTIS PB No. 253982.

20. Gart, J.; Chu, K.; Tarone, R. (1979) Statistical issues in interpretation of chronic bioassay tests for carcinogenicity. J. Natl. Cancer Inst. 62(4):957-974.

21. Gunter, B.; Lucas, J. (1973) Health Hazard Evaluation Determination Report No. 72-86-38, USDHEW, NIOSH. Cincinnati: Gates Rubber Co.

22. Hazleton Labs Europe, (1981) The Toxicity and Carcinogenicity of Butadiene Gas Adminis. tered to Rats by Inhalation for Approximately 24 Months. Unpublished report submitted to The International Institute of Synthetic Rubber Producers, Inc., New York. (Available from sponsor: 2077 S. Gessner Rd., Suite 133, Houston, TX 77063).

23. International Agency for Research on Cancer (IARC) (1982) IARC Monographs on the Evaluation of the Carcinogenic Risk of Chemicals to Humans: The Rubber Industry, Vol. 28. Lyon, France.

24. International Labor Office (1977) Occupational Exposure Limits for Airborne Toxic Substances. Occupational Safety and Health Series No. 37. Geneva: International Labor Office.

25. Kaplan, E.; Meier, P. (1958) Nonparametric estimation of incomplete observations. J. Am. Stat. Assoc. 53:457-481.

26. Knaap, A.; Voogd, C.; Kramers, P. (1982) Comparison of the mutagenic potency of 2chloroethanol, 2-bromoethanol, 1,2-epoxybutane, epichlorohydrin and glycidaldehyde in Klebsiella pneumoniae, Drosophila melanogaster and L5178Y mouse lymphoma cells. Mutat. Res. 101:199-208.

27. Kølmark, G.; Giles, N. (1955) Comparative studies of monoepoxides as inducers of reverse mutations in Neurospora. Genetics 40:890-902.
28. Kraybill, H. (1980) Evaluation of public health aspects of carcinogenic/mutagenic biorefractories in drinking water. Preventive Medicine 9:212-218.

29. Linhart, M.; Cooper, J.; Martin, R.; Page, N.; Peters, J.(1974) Carcinogenesis bioassay data system. Comp. Biomed. Res. 7:230-248.

30. Malvoisin, E.; Roberfroid, M. (1982) Hepatic microsomal metabolism of 1,3-butadiene. Xenobiotica 12:137-144.

31. Malvoisin, E.; Lhoest, G.; Poncelet, F.; Roberfroid, M.; Mercier, M. (1979) Identification and quantitation of 1,2-epoxybutene-3 as the primary metabolite of 1,3-butadiene. J. Chromatog. 178(2):419-426.

32. Malvoisin, E.; Roberfroid, M.; Mercier, M. (1980) Microsomal metabolism of butadiene. Toxicol. Lett. 6(2):163.

33. Mantel, N.; Haenszel, W. (1959) Statistical aspects of the analysis of data from retrospective studies of disease. J. Natl. Cancer Inst. 22:719748.

34. Maronpot, R.R.; Boorman, G.A. (1982) Interpretation of rodent hepatocellular proliferative alterations and hepatocellular tumors in chemical safety assessment. Toxicol. Pathol. 10:71-80.

35. Matanoski, G.; Schwartz, L.; Sperrazza, J.; Tonascia, J. (1982) Mortality of Workers in the Styrene-Butadiene Rubber Polymer Manufacturing Industry. Baltimore, MD: Johns Hopkins Univ. School of Hygiene and Public Health.

36. McCann, J.; Choi, E.; Yamasaki, E.; Ames, B. (1975) Detection of carcinogens as mutagens in the Salmonella/microsome test: Assay of 300 chemicals. Proc. Nat1. Acad. Sci. (USA) 72:51355139.

37. McMichael, A.; Spiritas, R.; Gamble, J.; Tousey, P. (1976) Mortality among rubber workers. Relationship to specific jobs. J. Occup. Med. 18(3):178-185. 
38. Meinhardt, T.; Young, R.; Hartle, R. (1978) Epidemiologic investigations of styrenebutadiene rubber production and reinforced plastics production. Scand. J. Work. Environ. 4(Suppl. 2):240-246.

39. Meinhardt, T.; Lemen, R.; Crandall, M.; Young, R. (1982) Environmental epidemiologic investigation of the styrene-butadiene rubber industry: mortality patterns with discussion of the hematopoietic and lymphatic malignancies. Scan. J. Work Environ. Health 8:250-259.

40. Migliore, L.; Rossi, A.; Loprieno, N. (1982) Mutagenic action of structurally related alkene oxides on Schizosaccharomyces pombe: The influence, in vitro, of mouse-liver metabolizing system. Mutat. Res. 102:425-437.

41. Mukhametova, G.; Murtaziana, L.; Gazizov, M.; Akhtyamova, A.; Kapakev, Z. (1976) Industrial hygiene and health status of workers involved in the production of 1,3-butadiene. Gig. Tr. Okhr. Zdorv'ya Rab. Nest. Neftekhim Prom. Sti. 9:29-31.

42. National Cancer Institute (NCI) (1976) Guidelines for Carcinogen Bioassay in Small Rodents. NCI Carcinogenesis Technical Report Series No. 1.

43. National Institute for Occupational Safety and Health (NIOSH) (1980) Projected Number of Occupational Exposures to Chemical and Physical Hazards. Cincinnati, $\mathrm{OH}$.

44. National Institutes of Health (NIH) (1978) NIH Specification NIH-11-133f, November 1.

45. Natusch, D. (1978) Potentially carcinogenic species emitted to the atmosphere by fossilfueled power plants. Environ. Health. Perspect. 22:79-90.

46. Neligan, R. (1962) Hydrocarbons in the Los Angeles atmosphere. Arch. Environ. Health 5:581-591.
47. Nikiforova, A.; Ripp, G.; Taskaev, I. (1969) Action of 1,3-butadiene on the structural elements of kidneys and hearts. Nauch. Tr. Ornsk. Med. Inst. 88:166-169. Cited in Parsons, T.; Wilkins, G. (1976) Biological Effects and Environmental Aspects of 1,3-Butadiene. USEPA Contract No. 68-01-3249. NTIS PB No. 253982.

48. Olszewska, E.; Kilbey, B. (1975) The mutagenic activity of diepoxybutane in yeast. Mutat. Res. 33:383-390.

49. Ong, T.-M.; de Serres, F. (1975) Mutation induction by difunctional alkylating agents in Neurospora crassa. Genetics 80:475-482.

50. Osborne, J.; Adamek, S.; Hobbs, M. (1956) Some components of gas phase in cigarette smoke. Anal. Chem 28:211-215.

51. Parsons, T.; Wilkins, G. (1976) Biological Effects and Environmental Aspects of 1,3-Butadiene. USEPA Contract No. 68-01-3249. NTIS PB No. 253982

52. Peto, R.; Pike, M.; Day, N.; Gray, R.; Lee, P.; Parish, S.; Peto, J.; Richards, S.: Wahrendorf, J. (1980) Annex. Guidelines for simple, sensitive, significance tests for carcinogenic effects in longterm animal experiments. Long-Term and Short-Term Screening Assays for Carcinogens: A Critical Appraisal, In: IARC Monographs on the Evaluation of the Carcinogenic Risk of Chemicals to Humans. Supplement 2--International Agency for Research on Cancer. Lyon, France, pp. 311-426.

53. Pienta, R. (1980) Transformation of Syrian hamster embryo cells by diverse chemicals and correlation with their reported carcinogenic and mutagenic activities. Chemical Mutagens: Principles and Methods for their Detection, Vol. 6. New York, pp. 175-202.

54. Poncelet, F.; de Meester, C.; Duverger-van Bogaert, M.; Lambotte-Vandepaer, M.; Roberfroid, M.; Mercier, M. (1980) Influence of experimental factors on the mutagenicity of vinylic monomers. Arch. Toxicol. Suppl. 4:63-66. 
55. Revnova, N. (1973) Dynamics of hematological indexes during adaptation to the effect of harmful industrial factors. Gig. Tr. 61-67.

56. Ripp, G. (1968) Toxicohygienic characteristics of 1,3-butadiene in the atmosphere. Naush. Tr. Ornsk. Med. Inst. 88:10.

57. Sankaranarayanan, K. (1983) The effects of butylated hydroxytoluene on radiation and chemically induced genetic damage in Drosophila melanogaster. Mutat. Res. 108:203-223.

58. Serebrennikov, O.A.; Ogleznev G.A. (1978) Developmental anomalies in the mother-fetus system following exposure to petrochemical products. Iss. Viniti, 151-152, 2667 (Chem. Abstr. 91:205223A).

59. Shugaev, B. (1969) Concentrations of hydrocarbons in tissues as a measure of toxicity. Arch. Environ. Health. 18:878-882.

60. Siddiqi, A.; Worley, F. (1977) Urban and industrial air pollutants in Houston, Texas--I. Hydrocarbons. Atmos. Environ. 11:131-143.

61. SRI International (1980) Directory of Chemical Producers U.S.A. Menlo Park, CA: SRI. Cited in USEPA, 1981: Chemical Hazard Information Profile--1,3-Butadiene. Draft Report.

62. Stephens, E. (1973) Hydrocarbons in polluted air. NTIS PB No. 230993.

63. Stephens, E.; Burleson, F. (1967) Analysis of the atmosphere for light hydrocarbons. J. Air Pollut. Control Assoc. 17:147-153.
64. Tarone, R. (1975) Tests for trend in life table analysis. Biometrika 62:679-682.

65. U.S. Code of Federal Regulations (USCFR) (1978, Rev. 1983) Title 21, Parts 175, 176, pp. 122-194.

66. U.S. Environmental Protection Agency (USEPA) (1978) Interim Primary Drinking Water Regulations. Fed. Reg. 43:29135-29150.

67. U.S. Environmental Protection Agency (USEPA) (1981) Chemical Hazard Information Profile--1,3-Butadiene. Draft Report.

68. Van Duuren, B. (1969) Carcinogenic epoxides, lactones and halo-ethers and their mode of action. Ann. N.Y. Acad. Sci. 163:633651 .

69. Volkova, Z.; Bagdinov, A. (1969) Industrial problems in vulcanization processes of rubber production. Gig. Sanit. 34:33-40. Cited in Miller, L. (1978) Investigation of Selected Potential Environmental Contaminants: Butadiene and its Oligomers. Philadelphia: Franklin Res. Center. USEPA NTIS PB-291684.

70. Voogd, C.; van der Stel, J.; Jacobs, J. (1981) The mutagenic action of aliphatic epoxides. Mutat. Res. 89:269-282.

71. Wilson, R.; McCormick, W. (1954) Toxicity of Plastics and Rubber Plastomers and Monomers. Ind. Med. Surg. 23:479-486.

72. Zlobina, M.; Dueva, I. (1974) Allergenic action of polybutadiene Latex SKOP and its volatile products. Chem. Abstr. 1978481:34129m. 


\section{APPENDIX A}

SUMMARY OF THE INCIDENCE OF NEOPLASMS

IN MICE IN THE SIXTY-ONE-WEEK INHALATION STUDIES OF 1,3-BUTADIENE 
TABLE A1. SUMMARY OF THE INCIDENCE OF NEOPLASMS IN MALE MICE IN THE SIXTY-ONE-WEEK INHALATION STUDY OF 1,3-BUTADIENE

\begin{tabular}{|c|c|c|c|}
\hline $\mathrm{COI}$ & TROL (CHAM) & LOW DOSE & HIGH DOSE \\
\hline $\begin{array}{l}\text { ANIMALS INITIALLY IN STUDY } \\
\text { ANIMALS NECROPSIED } \\
\text { ANIMALS EXAMINED HISTOPATHOLOGICALLY }\end{array}$ & $\begin{array}{l}50 \\
50 \\
50\end{array}$ & $\begin{array}{l}50 \\
50 \\
50\end{array}$ & $\begin{array}{l}50 \\
50 \\
49\end{array}$ \\
\hline $\begin{array}{l}\text { INTEGUMENTARY SYSTEM } \\
\text { *MULTIPLE ORGANS } \\
\text { FIBROUS HISTIOCYTOMA, MALIGNANT }\end{array}$ & $(50)$ & $\left.{ }_{1}^{(50)}\right)_{(2 \%)}$ & $(50)$ \\
\hline $\begin{array}{l}\text { RESPIRATORY SYSTEM } \\
\text { *NASAL CAVITY } \\
\text { GLIOMA, INVASIVE } \\
\text { \#LUNG } \\
\text { ALVEOLAR/BRONCHIOLAR ADENOMA } \\
\text { ALVEOLAR/BRONCHIOLAR CARCINOMA }\end{array}$ & $\begin{array}{l}(50) \\
(50) \\
2(4 \%)\end{array}$ & $\begin{aligned}(50) & \\
1 & (2 \%) \\
(49) & (24 \%) \\
12 & (24 \%) \\
2 & (4 \%)\end{aligned}$ & $\begin{aligned}(50) & \\
1 & (2 \%) \\
(49) & \\
11 & (22 \%) \\
5 & (10 \%)\end{aligned}$ \\
\hline $\begin{array}{l}\text { HEMATOPOIETIC SYSTEM } \\
\text { *MULTIPLE ORGANS } \\
\text { MALIGNANT LYMPHOMA, NOS } \\
\text { \#THYMUS } \\
\text { MALIGNANT LYMPHOMA, NOS }\end{array}$ & $\begin{array}{l}(50) \\
(43)\end{array}$ & $\begin{array}{rr}(50) & \\
22 & (44 \%) \\
(20) & \\
1 & (5 \%)\end{array}$ & $\begin{aligned}(50) & \\
28 & (56 \%) \\
(13) & \\
1 & (8 \%)\end{aligned}$ \\
\hline $\begin{array}{l}\text { CIRCULATORY SYSTEM } \\
\text { *MEDIASTINUM } \\
\text { HEMANGIOSARCOMA, METASTATIC } \\
\text { "PERITONEAL CAVITY } \\
\text { HEMANGIOSARCOMA } \\
\text { \#LUNG } \\
\text { HEMANGIOSARCOMA, METASTATIC } \\
\text { \#HEART } \\
\text { HEMANGIOSARCOMA } \\
\text { \#LIVER } \\
\text { HEMANGIOSARCOMA, METASTATIC } \\
\text { \#PANCREAS } \\
\text { HEMANGIOSARCOMA, INVASIVE } \\
\text { \# KIDNEY } \\
\text { HEMANGIOSARCOMA, INVASIVE } \\
\text { HEMANGIOSARCOMA, METASTATIC }\end{array}$ & $\begin{array}{l}(50) \\
(50) \\
(50) \\
(50) \\
(50) \\
(50) \\
(50)\end{array}$ & 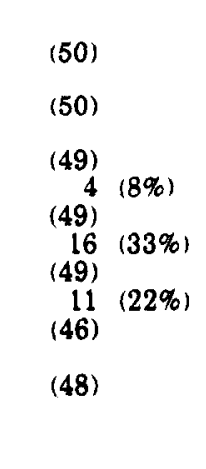 & $\begin{aligned}(50) & \\
1 & (2 \%) \\
(50) & \\
1 & (2 \%) \\
(49) & \\
& \\
(49) & \\
7 & (14 \%) \\
(49) & \\
5 & (10 \%) \\
(46) & \\
1 & (2 \%) \\
(48) & \\
1 & (2 \%) \\
1 & (2 \%)\end{aligned}$ \\
\hline $\begin{array}{l}\text { DIGESTIVE SYSTEM } \\
\text { \#LIVER } \\
\text { HEPATOCELLULAR ADENOMA } \\
\text { HEPATOCELLULAR CARCINOMA } \\
\text { \#FORESTOMACH } \\
\text { PAPILLOMA, NOS } \\
\text { SQUAMOUS CELL PAPILLOMA } \\
\text { SQUAMOUS CELL CARCINOMA }\end{array}$ & $\begin{aligned}(50) & \\
5 & (10 \%) \\
3 & (6 \%) \\
(49) & \end{aligned}$ & $\begin{array}{rr}(49) & \\
4 & (8 \%) \\
2 & (4 \%) \\
(40) & \\
3 & (8 \%) \\
2 & (5 \%) \\
2 & (5 \%)\end{array}$ & $\begin{array}{rr}(49) & \\
1 & (2 \%) \\
1 & (2 \%) \\
(44) & \\
1 & (2 \%)\end{array}$ \\
\hline $\begin{array}{l}\text { URINARY SYSTEM } \\
\text { \#KIDNEY } \\
\text { ALVEOLAR/BRONCHIOLAR CA, METASTA }\end{array}$ & $(50)$ & $(48)$ & $\stackrel{(48)}{1}(2 \%)$ \\
\hline $\begin{array}{l}\text { ENDOCRINE SYSTEM } \\
\text { \#THYROID } \\
\text { FOLLICULAR-CELL ADENOMA }\end{array}$ & $\stackrel{(50)}{l(2 \%)}$ & (43) & (47) \\
\hline $\begin{array}{l}\text { REPRODUCTIVE SYSTEM } \\
\text { *PREPUTIAL GLAND } \\
\text { CARCINOMA, NOS } \\
\text { SQUAMOUS CELL CARCINOMA }\end{array}$ & $(50)$ & $\begin{array}{l}(50) \\
3(6 \%)\end{array}$ & $\begin{aligned}(50) & \\
1 & (2 \%) \\
1 & (2 \%)\end{aligned}$ \\
\hline
\end{tabular}


TABLE A1. SUMMARY OF THE INCIDENCE OF NEOPLASMS IN MALE MICE IN THE SIXTY-ONE-WEEK INHALATION STUDY OF 1,3-BUTADIENE (Continued)

\begin{tabular}{|c|c|c|c|}
\hline \multicolumn{2}{|c|}{ CONTROL (CHAM) } & LOW DOSE & HIGH DOSE \\
\hline $\begin{array}{c}\text { NERVOUS SYSTEM } \\
\text { \#BRAIN } \\
\text { GLIOMA, NOS } \\
\text { EPENDYMOMA }\end{array}$ & $(50)$ & $\begin{array}{rr}(48) & \\
2 & (4 \%) \\
1 & (2 \%)\end{array}$ & $\stackrel{(49)}{1}(2 \%)$ \\
\hline $\begin{array}{l}\text { SPECIAL SENSE ORGANS } \\
\text { *ZYMBAL GLAND } \\
\text { CARCINOMA, NOS }\end{array}$ & $(50)$ & $(50)$ & $\stackrel{(50)}{2}(4 \%)$ \\
\hline $\begin{array}{l}\text { MUSCULOSKELETAL SYSTEM } \\
\text { *MUSCLE OF THORAX } \\
\text { ALVEOLAR/BRONCHIOLAR CA, INVASIV }\end{array}$ & $(50)$ & $(50)$ & $\stackrel{(50)}{1}(2 \%)$ \\
\hline \multicolumn{4}{|l|}{$\begin{array}{l}\text { BODY CAVITIES } \\
\text { NONE }\end{array}$} \\
\hline $\begin{array}{l}\text { ALL OTHER SYSTEMS } \\
\text { *MULTIPLE ORGANS } \\
\text { SQUAMOUS CELL CARCINOMA, METASTA }\end{array}$ & $(50)$ & $\stackrel{(50)}{1}(2 \%)$ & $\stackrel{(50)}{1}(2 \%)$ \\
\hline \multicolumn{4}{|c|}{$\begin{array}{l}\text { \# NUMBER OF ANIMALS WITH TISSUE EXAMINED MICROSCOPICALLY } \\
\text { * NUMBER OF ANIMALS NECROPSIED }\end{array}$} \\
\hline $\begin{array}{l}\text { ANIMAL DISPOSITION SUMMARY } \\
\text { ANIMALSINITIALLY IN STUDY } \\
\text { NATURAL DEATH } \\
\text { MORIBUND SACRIFICE } \\
\text { SCHEDULED SACRIFICE } \\
\text { TERMINAL SACRIFICE } \\
\text { DOSING ACCIDENT } \\
\text { ACCIDENTALLY KILLED, NDA } \\
\text { ACCIDENTALLY KILLED, NOS } \\
\text { ANIMAL MISSING } \\
\text { ANIMAL MISSEXED } \\
\text { OTHER CASES }\end{array}$ & $\begin{array}{r}50 \\
1 \\
49\end{array}$ & $\begin{array}{r}50 \\
30 \\
9 \\
11\end{array}$ & $\begin{array}{r}50 \\
31 \\
8 \\
7\end{array}$ \\
\hline $\begin{array}{l}\text { TUMOR SUMMARY } \\
\text { TOTAL ANIMALS WITH PRIMARY TUMORS** } \\
\text { TOTAL PRIMARY TUMORS } \\
\text { TOTAL ANIMALS WITH BENIGN TUMORS } \\
\text { TOTAL BENIGN TUMORS } \\
\text { TOTAL ANIMALS WITH MALIGNANT TUMORS } \\
\text { TOTAL MALIGNANT TUMORS } \\
\text { TOTAL ANIMALS WITH SECONDARY TUMORS\# } \\
\text { TOTAL SECONDARY TUMORS } \\
\text { TOTAL ANIMALS WITH TUMORS UNCERTAIN- } \\
\text { BENIGN OR MALIGNANT } \\
\text { TOTAL UNCERTAIN TUMORS } \\
\text { TOTAL ANIMALS WITH TUMORS UNCERTAIN- } \\
\text { PRIMARY OR METASTATIC } \\
\text { TOTAL UNCERTAIN TUMORS }\end{array}$ & $\begin{array}{r}10 \\
11 \\
8 \\
8 \\
3 \\
3 \\
3\end{array}$ & $\begin{array}{l}44 \\
73 \\
16 \\
21 \\
40 \\
52 \\
14 \\
17\end{array}$ & $\begin{array}{r}40 \\
61 \\
11 \\
12 \\
40 \\
49 \\
9 \\
13\end{array}$ \\
\hline $\begin{array}{l}\text { ** PRIMARY TUMORS: ALL TUMORS EXCEPT SEC } \\
\text { \#\# SECONDARY TUMORS: METASTATIC TUMORS }\end{array}$ & $\begin{array}{l}\text { NDARY TUMO } \\
\text { OR TUMORS IN }\end{array}$ & INTO AN AI & RGAN \\
\hline
\end{tabular}


TABLE A2. SUMMARY OF THE INCIDENCE OF NEOPLASMS IN FEMALE MICE IN THE SIXTY-ONEWEEK INHALATION STUDY OF 1,3-BUTADIENE

\begin{tabular}{|c|c|c|c|c|}
\hline CONT & TROL (CHAM) & LOW DOSE & HIGH & DOSE \\
\hline $\begin{array}{l}\text { ANIMALS INITIALLY IN STUDY } \\
\text { ANIMALS MISSING } \\
\text { ANIMALS NECROPSIED } \\
\text { ANIMALS EXAMINED HISTOPATHOLOGICALLY }\end{array}$ & $\begin{array}{l}50 \\
50 \\
50\end{array}$ & $\begin{array}{l}50 \\
49 \\
49\end{array}$ & $\begin{array}{r}50 \\
1 \\
49 \\
49\end{array}$ & \\
\hline $\begin{array}{l}\text { INTEGUMENTARY SYSTEM } \\
\text { *SUBCUT TISSUE } \\
\text { SARCOMA, NOS } \\
\text { FIBROUS HISTIOCYTOMA, MALIGNANT } \\
\text { OSTEOSARCOMA }\end{array}$ & $1(2 \%)$ & $\begin{array}{rr}(49) & \\
2 & (4 \%) \\
1 & (2 \%)\end{array}$ & $\begin{array}{r}\text { (49) } \\
2\end{array}$ & $(4 \%)$ \\
\hline $\begin{array}{l}\text { RESPIRATORY SYSTEM } \\
\text { \#LUNG } \\
\text { HEPATOCELLULAR CARCINOMA, METAST } \\
\text { ALVEOLAR/BRONCHIOLAR ADENOMA } \\
\text { ALVEOLAR/BRONCHIOLAR CARCINOMA } \\
\text { ACINAR-CELL CARCINOMA, METASTATIC } \\
\text { ADENOSQUAMOUS CARCINOMA, METASTAT } \\
\text { GRANULOSA-CELL CARCINOMA, METASTAT } \\
\text { OSTEOSARCOMA, METASTATIC }\end{array}$ & $\begin{array}{l}(49) \\
3 \quad(6 \%) \\
\text { IC } \\
\quad 1(2 \%)\end{array}$ & $\begin{aligned}(48) & \\
1 & (2 \%) \\
9 & (19 \%) \\
6 & (12 \%) \\
1 & (2 \%) \\
3 & (6 \%)\end{aligned}$ & $\begin{array}{r}(49) \\
20 \\
8 \\
1 \\
1\end{array}$ & $\begin{array}{l}(41 \%) \\
(16 \%) \\
(2 \%) \\
(2 \%)\end{array}$ \\
\hline $\begin{array}{l}\text { HEMATOPOIETIC SYSTEM } \\
\text { "MULTIPLE ORGANS } \\
\text { MALIGNANT LYMPHOMA, NOS } \\
\text { \#LYMPH NODE } \\
\text { ALVEOLAR/BRONCHIOLAR CA, METASTATIC } \\
\text { GRANULOSA-CELL CARCINOMA, METASTATI } \\
\text { \#LIVER } \\
\text { MALIGNANT LYMPHOMA, NOS } \\
\text { \#THYMUS } \\
\text { MALIGNANT LYMPHOMA, NOS }\end{array}$ & $\begin{array}{l}(50) \\
1 \\
(46) \\
(2 \%) \\
(50) \\
(47)\end{array}$ & $\begin{array}{ll}(49) & \\
8 & (16 \%) \\
(41) & \\
(47) & \\
1 & (2 \%) \\
(21) & \\
1 & (5 \%)\end{array}$ & $\begin{array}{r}(49) \\
10 \\
(44) \\
1 \\
1 \\
(49) \\
(33)\end{array}$ & $\begin{array}{l}(20 \%) \\
(2 \%) \\
(2 \%)\end{array}$ \\
\hline $\begin{array}{l}\text { CIRCULATORY SYSTEM } \\
\text { *MULTIPLE ORGANS } \\
\text { HEMANGIOSARCOMA, METASTATIC } \\
\text { *SUBCUT TISSUE } \\
\text { HEMANGIOSARCOMA } \\
\text { HEMANGIOSARCOMA, METASTATIC } \\
\text { \#LYMPH NODE } \\
\text { HEMANGIOSARCOMA, METASTATIC } \\
\text { \#LUNG } \\
\text { HEMANGIOSARCOMA, METASTATIC } \\
\text { \#HEART } \\
\text { HEMANGIOSARCOMA } \\
\text { NEUROFIBROSARCOMA } \\
\text { \#LIVER } \\
\text { HEMANGIOSARCOMA } \\
\text { HEMANGIOSARCOMA, METASTATIC }\end{array}$ & $\begin{array}{l}(50) \\
(50) \\
(46) \\
(49) \\
(49) \\
(50)\end{array}$ & $\begin{aligned}(49) & \\
1 & (2 \%) \\
(49) & \\
2 & (4 \%) \\
1 & (2 \%) \\
(41) & \\
& \\
(48) & \\
4 & (8 \%) \\
(48) & \\
11 & (23 \%) \\
& \\
(47) & \\
7 & (15 \%)\end{aligned}$ & $\begin{array}{r}(49) \\
(49) \\
\\
(44) \\
1 \\
(49) \\
6 \\
(49) \\
18 \\
1 \\
(49) \\
1 \\
9\end{array}$ & $\begin{array}{l}(2 \%) \\
(12 \%) \\
(37 \%) \\
(2 \%) \\
(2 \%) \\
(18 \%)\end{array}$ \\
\hline $\begin{array}{l}\text { DIGESTIVE SYSTEM } \\
\text { \#SALIVARY GLAND } \\
\text { CARCINOSARCOMA } \\
\text { \#LIVER } \\
\text { HEPATOCELLULAR ADENOMA } \\
\text { HEPATOCELLULAR CARCINOMA } \\
\text { \#PANCREAS } \\
\text { ADENOCARCINOMA, NOS } \\
\text { \#FORESTOMACH } \\
\text { PAPILLOMA, NOS } \\
\text { SQUAMOUSCELL PAPILLOMA } \\
\text { SQUAMOUS CELL CARCINOMA }\end{array}$ & $\begin{array}{l}(46) \\
(50) \\
(49) \\
(49)\end{array}$ & $\begin{array}{rr}(45) & \\
(47) & \\
1 & (2 \%) \\
1 & (2 \%) \\
(45) & \\
& \\
(42) & \\
1 & (2 \%) \\
3 & (7 \%) \\
1 & (2 \%)\end{array}$ & $\begin{array}{r}(46) \\
1 \\
(49) \\
4 \\
1 \\
(48) \\
1 \\
149) \\
9 \\
1 \\
1\end{array}$ & $\begin{array}{l}(2 \%) \\
(8 \%) \\
(2 \%) \\
(2 \%) \\
(18 \%) \\
(2 \%) \\
(2 \%)\end{array}$ \\
\hline
\end{tabular}


TABLE A2. SUMMARY OF THE INCIDENCE OF NEOPLASMS IN FEMALE MICE IN THE SIXTY.ONEWEEK INHALATION STUDY OF 1,3-BUTADIENE (Continued)

\begin{tabular}{|c|c|c|c|}
\hline & CONTROL (CHAM) & LOW DOSE & HIGH DOSE \\
\hline $\begin{array}{l}\text { URINARY SYSTEM } \\
\text { \# KIDNEY } \\
\text { TUBULAR-CELL ADENOMA } \\
\text { NEUROFIBROSARCOMA, METASTATIC }\end{array}$ & (49) & $\begin{array}{r}(47) \\
1\end{array}$ & $\begin{array}{l}(49) \\
1(2 \%)\end{array}$ \\
\hline $\begin{array}{l}\text { ENDOCRINE SYSTEM } \\
\text { \#THYROID } \\
\text { FOLLICULAR-CELL ADENOMA }\end{array}$ & (48) & $\begin{array}{l}(46) \\
1\end{array}$ & (49) \\
\hline $\begin{array}{l}\text { REPRODUCTIVE SYSTEM } \\
\text { "MAMMARY GLAND } \\
\text { ACINAR-CELL CARCINOMA } \\
\text { ADENOSQUAMOUS CARCINOMA } \\
\text { \#UTERUS } \\
\text { ENDOMETRIAL STROMAL POLYP } \\
\text { \#OVARY } \\
\text { CYSTADENOMA, NOS } \\
\text { GRANULOSA-CELL TUMOR } \\
\text { GRANULOSA-CELLCARCINOMA } \\
\text { TUBULAR ADENOMA } \\
\text { MIXED TUMOR, BENIGN }\end{array}$ & $\begin{array}{l}(50) \\
(49) \\
1 \\
(49)\end{array}$ & $\begin{aligned}(49) & \\
2 & (4 \%) \\
4 & (8 \%) \\
(46) & \\
& \\
(45) & \\
1 & (2 \%) \\
6 & (13 \%) \\
2 & (4 \%)\end{aligned}$ & $\begin{aligned}(49) & \\
6 & (12 \%) \\
(49) & \\
(48) & \\
12 & (25 \%) \\
1 & (2 \%) \\
2 & (4 \%)\end{aligned}$ \\
\hline \multicolumn{4}{|l|}{$\begin{array}{l}\text { NERVOUS SYSTEM } \\
\text { NONE }\end{array}$} \\
\hline $\begin{array}{l}\text { SPECIAL SENSE ORGANS } \\
\text { *ZYMBAL GLAND } \\
\text { CARCINOMA,NOS }\end{array}$ & $(50)$ & (49) & $\stackrel{(49)}{1}(2 \%)$ \\
\hline $\begin{array}{l}\text { MUSCULOSKELETAL SYSTEM } \\
\text { *BONE } \\
\text { OSTEOSARCOMA }\end{array}$ & $(50)$ & $\stackrel{(49)}{1}(2 \%)$ & (49) \\
\hline \multicolumn{4}{|l|}{$\begin{array}{l}\text { BODY CAVITIES } \\
\text { NONE }\end{array}$} \\
\hline
\end{tabular}


TABLE A2. SUMMARY OF THE INCIDENCE OF NEOPLASMS IN FEMALE MICE IN THE SIXTY-ONEWEEK INHALATION STUDY OF 1,3-BUTADIENE (Continued)

\begin{tabular}{|c|c|c|c|}
\hline \multicolumn{2}{|c|}{ CONTROL (CHAM) } & LOW DOSE & HIGH DOSE \\
\hline $\begin{array}{l}\text { ANIMAL DISPOSITION SUMMARY } \\
\text { ANIMALS INITIALLY IN STUDY } \\
\text { NATURAL DEATH } \\
\text { MORIBUND SACRIFICE } \\
\text { SCHEDULED SACRIFICE } \\
\text { TERMINALSACRIFICE } \\
\text { DOSING ACCIDENT } \\
\text { ACCIDENTALLY KILLED, NDA } \\
\text { ACCIDENTALLY KILLED, NOS } \\
\text { ANIMAL MISSING } \\
\text { ANIMAL MISSEXED } \\
\text { OTHER CASES }\end{array}$ & $\begin{array}{r}50 \\
4 \\
46\end{array}$ & $\begin{array}{r}50 \\
26 \\
7 \\
14 \\
\\
\\
3\end{array}$ & $\begin{array}{r}50 \\
12 \\
6 \\
30 \\
\\
1 \\
1\end{array}$ \\
\hline $\begin{array}{l}\text { TUMOR SUMMARY } \\
\text { TOTAL ANIMALS WITH PRIMARY TUMORS** } \\
\text { TOTAL PRIMARY TUMORS } \\
\text { TOTALANIMALS WITH BENIGN TUMORS } \\
\text { TOTAL BENIGN TUMORS } \\
\text { TOTALANIMALS WITH MALIGNANT TUMORS } \\
\text { TOTAL MALIGNANT TUMORS } \\
\text { TOTAL ANIMALS WITH SECONDARY TUMORS\# \# } \\
\text { TOTAL SECONDARY TUMORS } \\
\text { TOTALANIMALS WITH TUMORS UNCERTAIN- } \\
\text { BENIGN OR MALIGNANT } \\
\text { TOTAL UNCERTAIN TUMORS } \\
\text { TOTALANIMALS WITH TUMORS UNCERTAIN- } \\
\text { PRIMARY OR METASTATIC } \\
\text { TOTAL UNCERTAIN TUMORS }\end{array}$ & $\begin{array}{l}6 \\
6 \\
4 \\
4 \\
2 \\
2 \\
1 \\
1\end{array}$ & $\begin{array}{r}40 \\
66 \\
15 \\
19 \\
35 \\
41 \\
18 \\
22 \\
\\
6 \\
6\end{array}$ & $\begin{array}{r}46 \\
100 \\
28 \\
36 \\
36 \\
52 \\
17 \\
24 \\
\\
12 \\
12\end{array}$ \\
\hline
\end{tabular}


TABLE A3. INDIVIDUAL ANIMAL TUMOR PATHOLOGY OF MALE MICE IN THE SIXTY-ONE-WEEK INHALATION STUDY OF 1,3-BUTADIENE : CHAMBER CONTROL

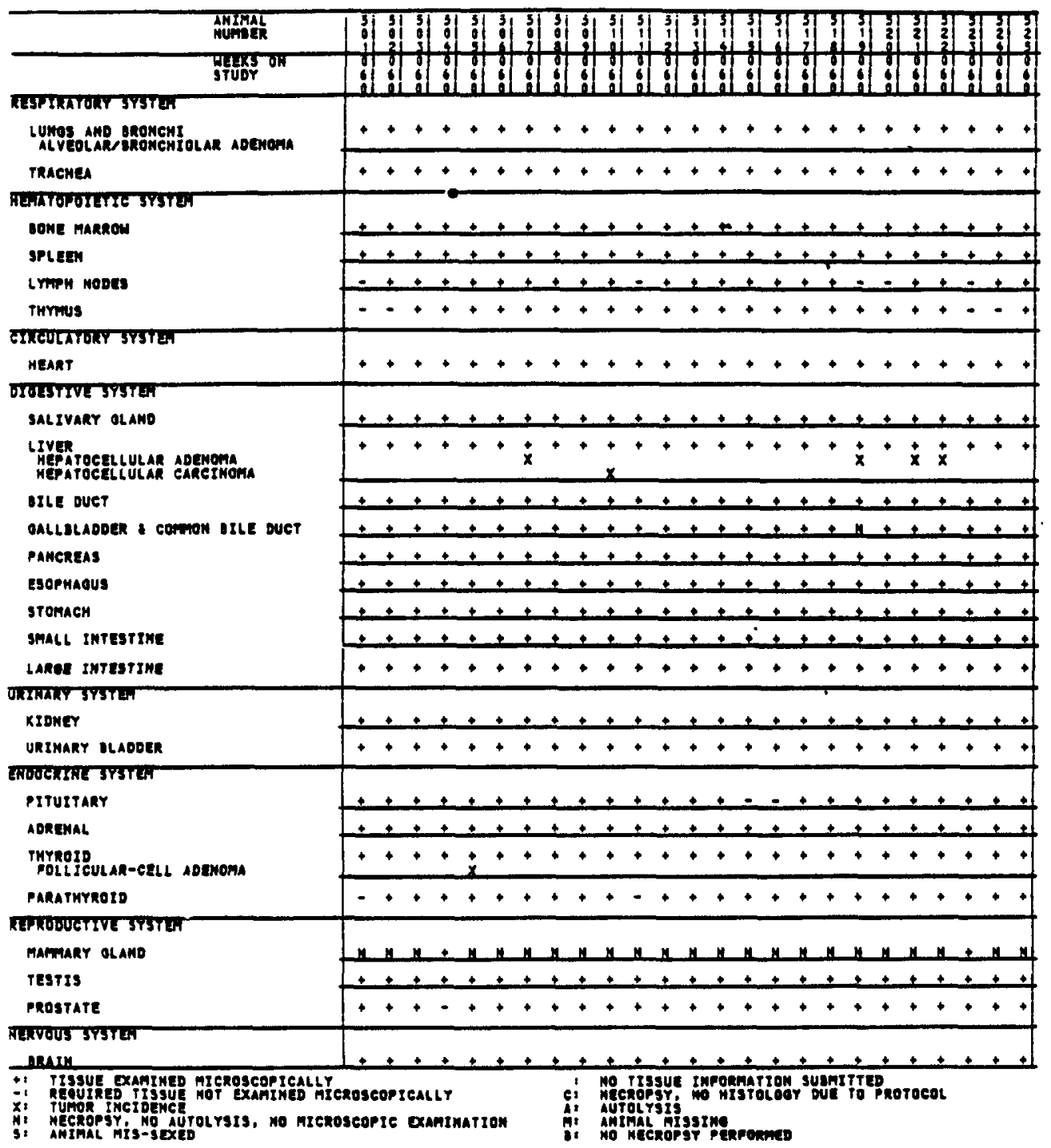


TABLE A3. INDIVIDUAL ANIMAL TUMOR PATHOLOGY OF MALE MICE : CHAMBER CONTROL (Continued)

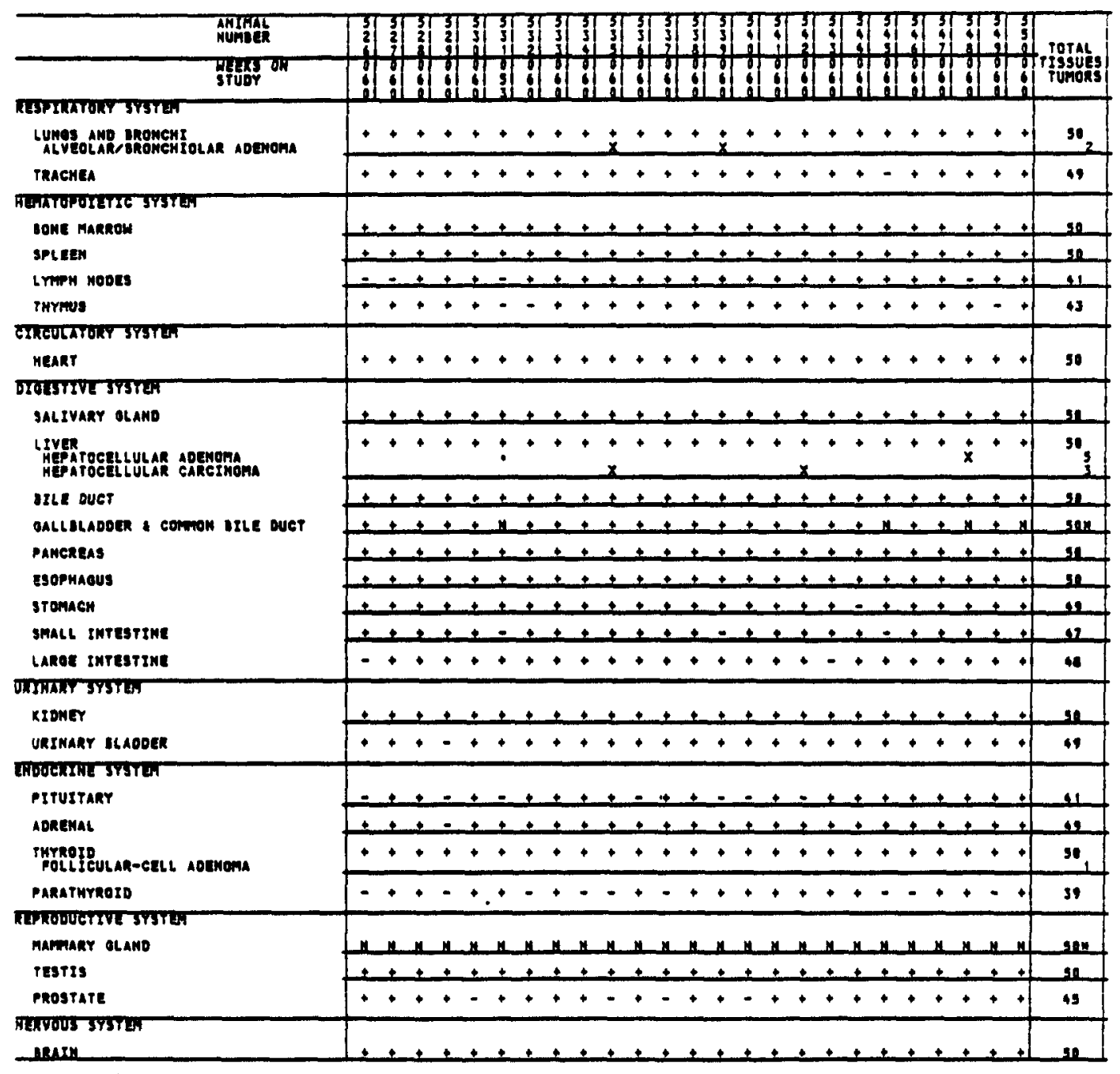

- animals hecropsred 
TABLE A3. INDIVIDUA ANIMAL TUMOR PATHOLOGY OF MALE MICE IN THE SIXTY-ONE-WEEK INHALATION STUDY OF 1,3-BUTADIENE : LOW DOSE

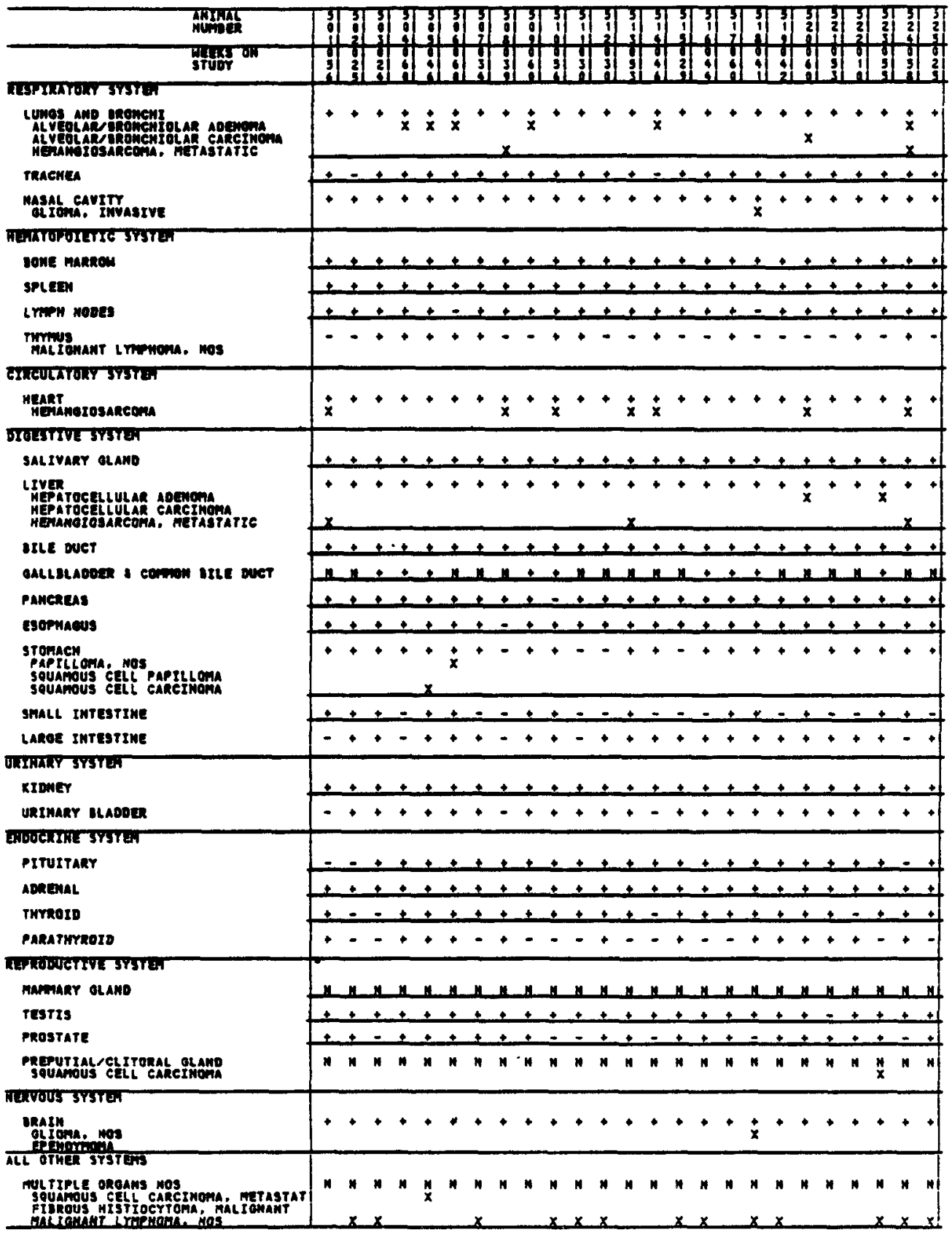


TABLE A3. INDIVIdUal ANIMAL TUMOR PATHOLOGY OF MALE MICE : LOW dose (Continued)

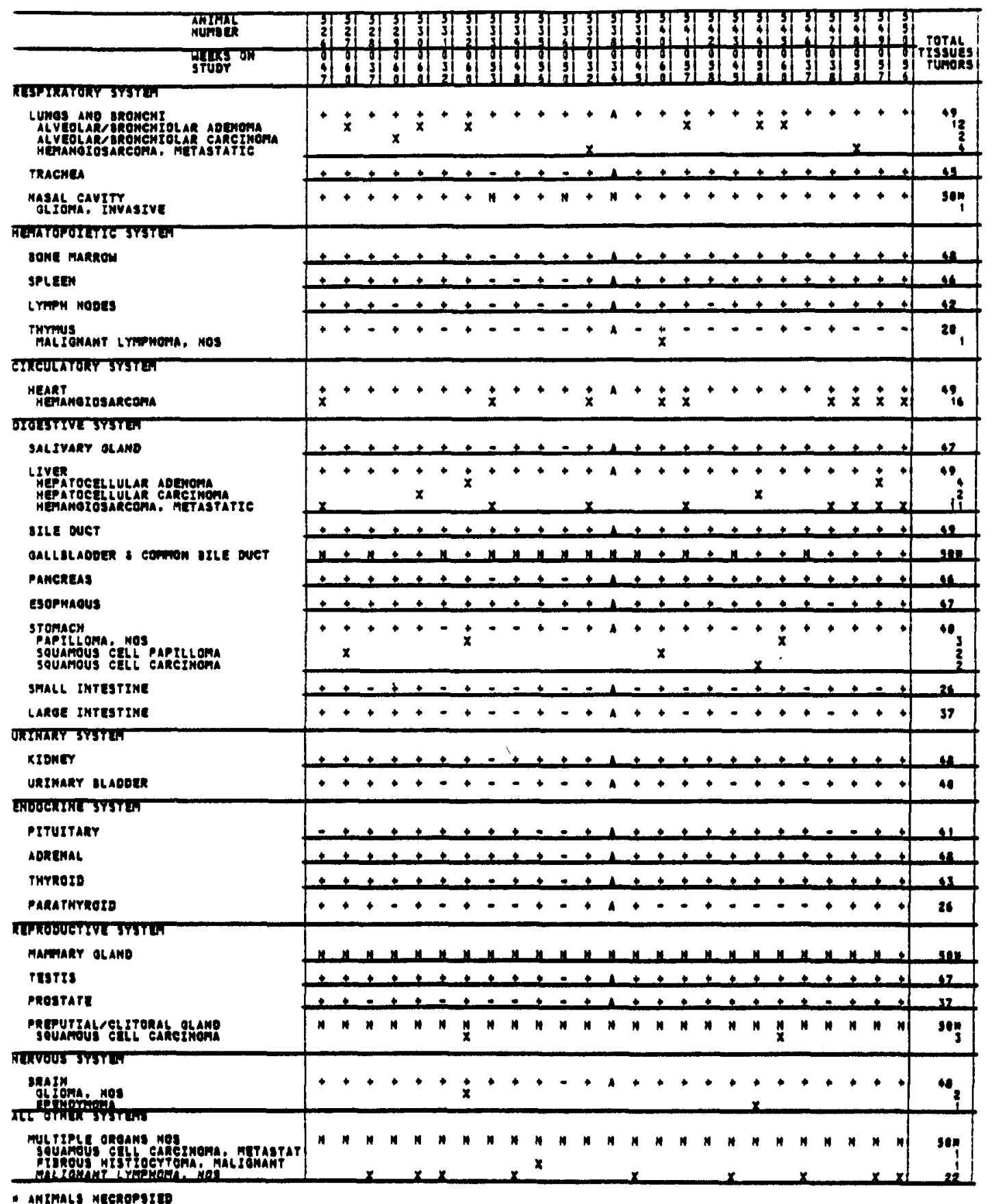


TABLE A3. INDIVIDUAL ANIMAL TUMOR PATHOLOGY OF MALE MICE IN THE SIXTY-ONE-WEEK INHALATION STUDY OF 1,3-BUTADIENE: HIGH DOSE

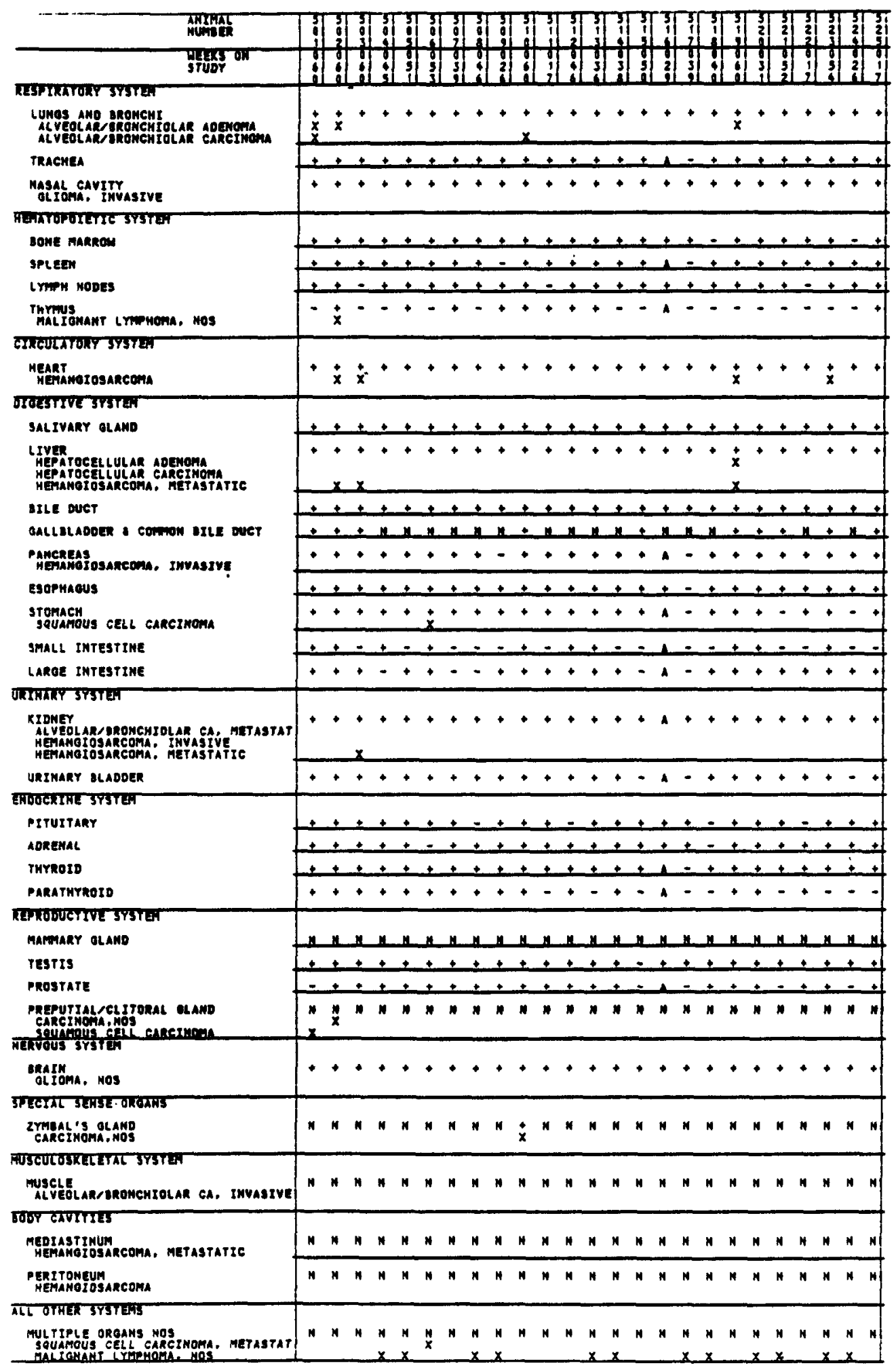


TABLE A3. INDIVIDUAL ANIMAL TUMOR PATHOLOGY OF MALE MICE : HIGH DOSE (Continued)

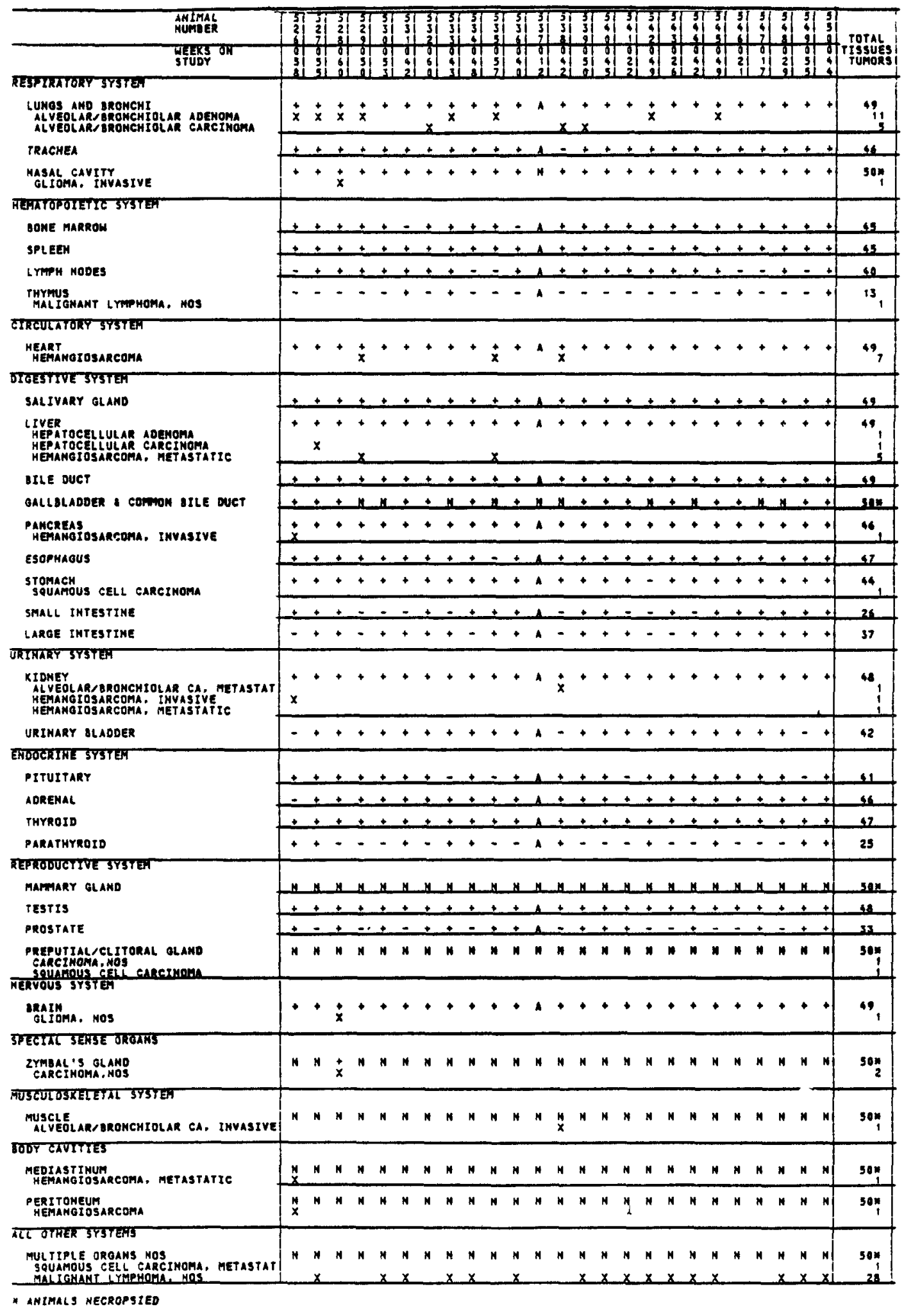


TABLE A4. INDTVIDUAL ANIMAL TUMOR PATHOLOGY OF FEMALE MICE IN THE SIXTY-ONE-WEEK INHALATION STUDY OF 1,3-BUTADIENE : CHAMBER CONTROL

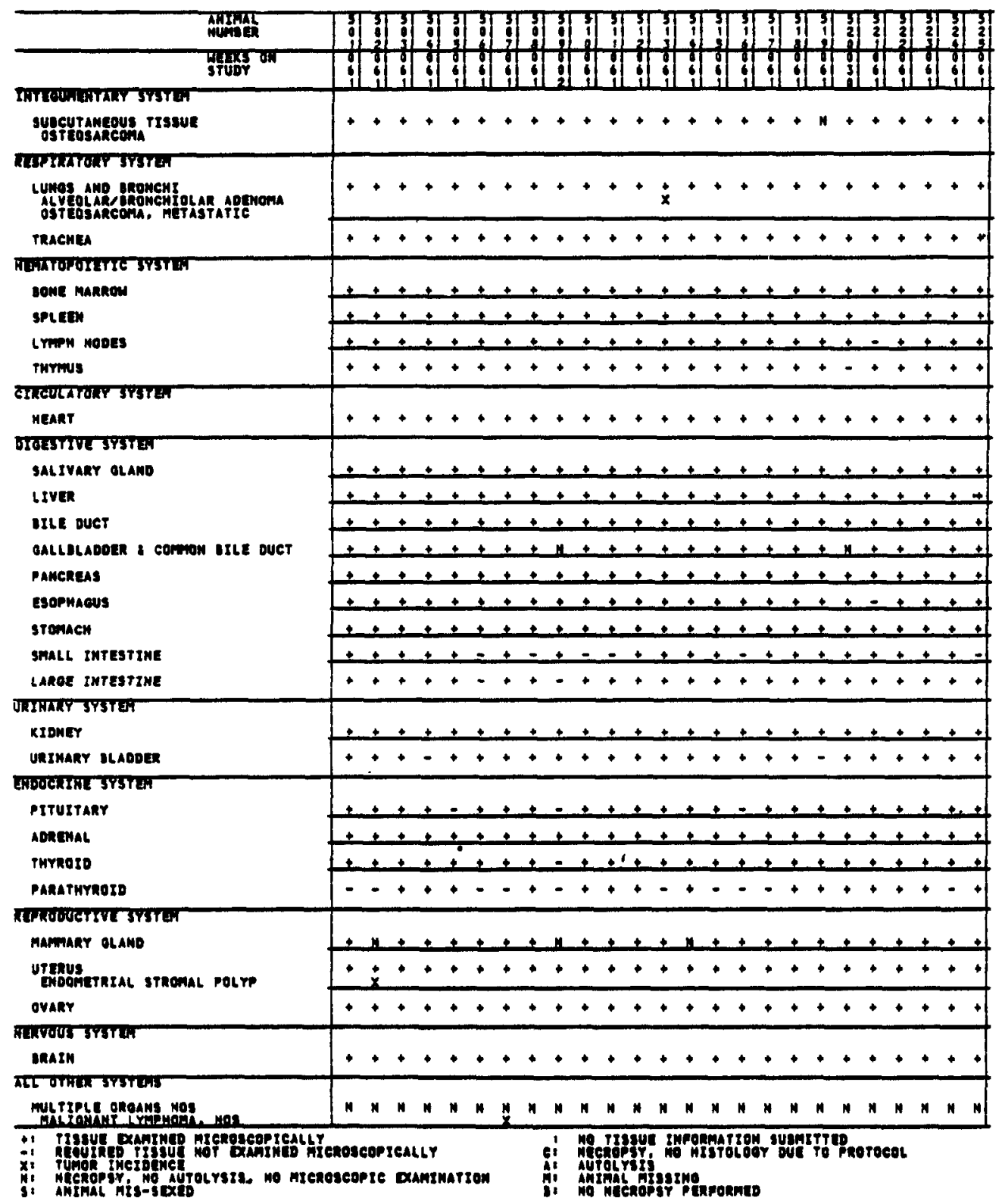


TABLE A4. INDIVIDUAL ANIMAL TUMOR PATHOLOGY OF FEMALE MICE : CHAMBER CONTROL (Continued)

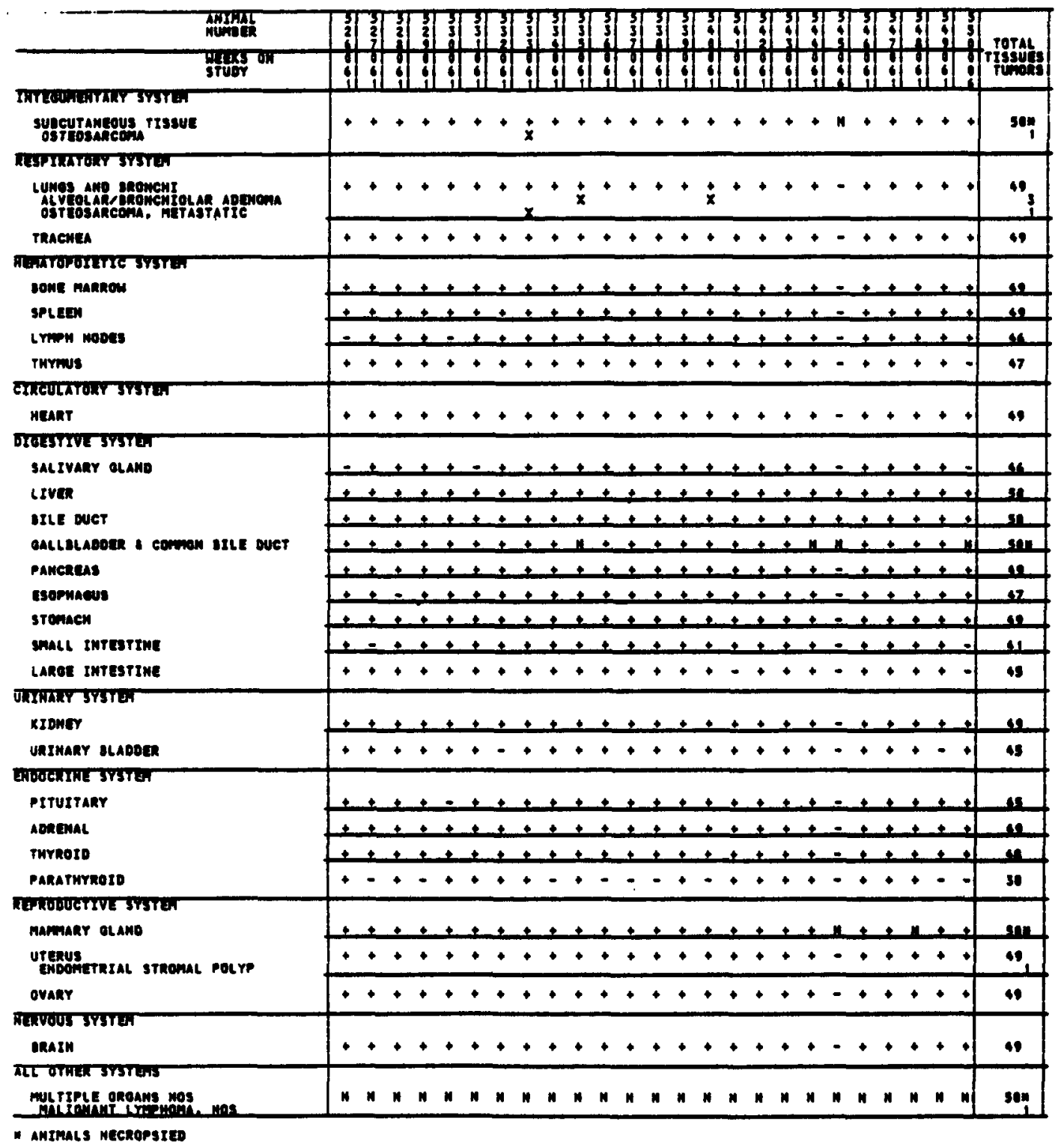


TABLE A4. INDIVIDUAL ANIMAL TUMOR PATHOLOGY OF FEMALE MICE IN THE SIXTY-ONE-WEEK INHALATION STUDY OF 1,3-BUTADIENE : LOW DOSE

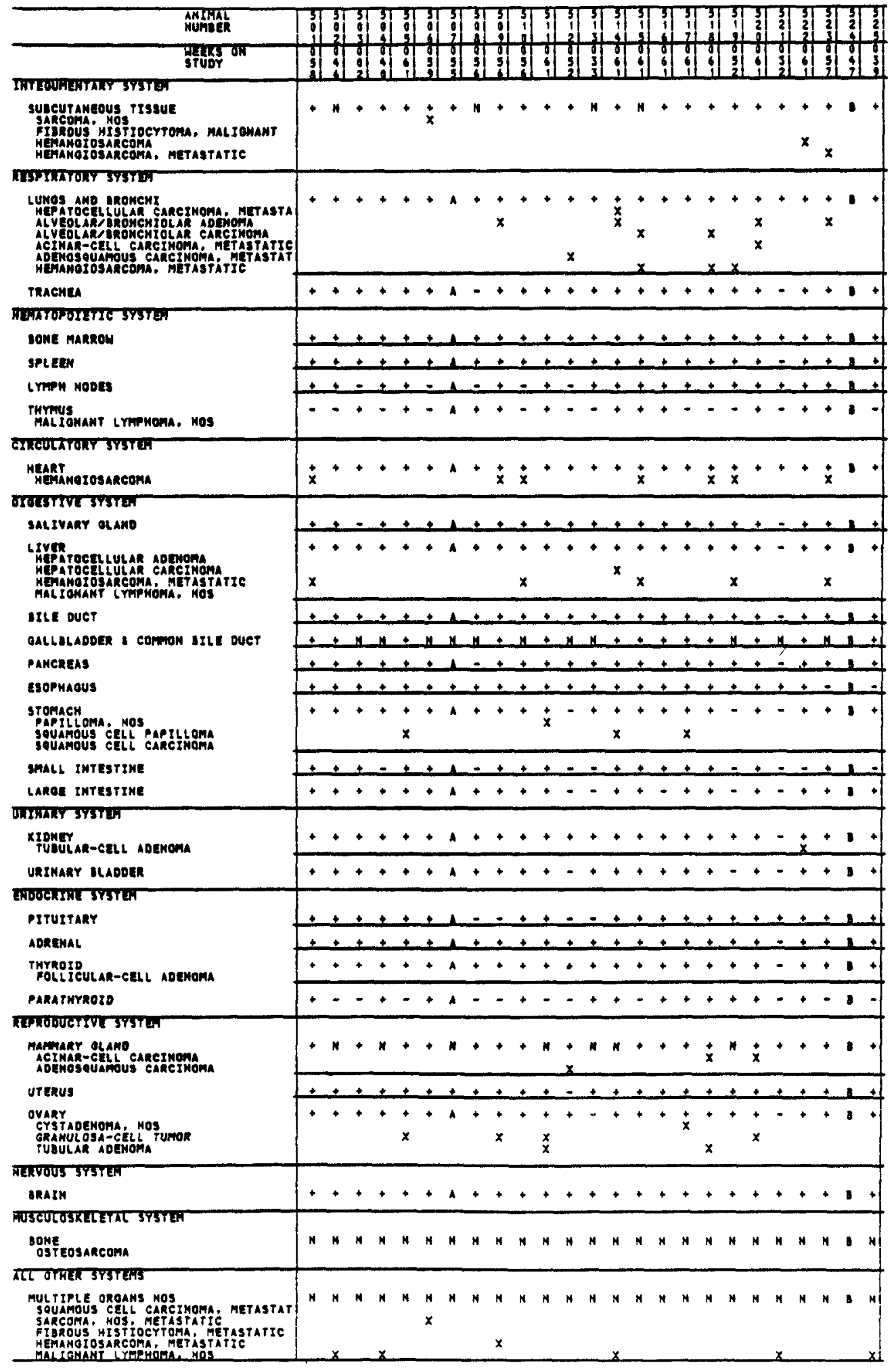


TABLE A4. INDIVIDUAL ANIMAL TUMOR PATHOLOGY OF FEMALE MICE : LOW DOSE (Continued)

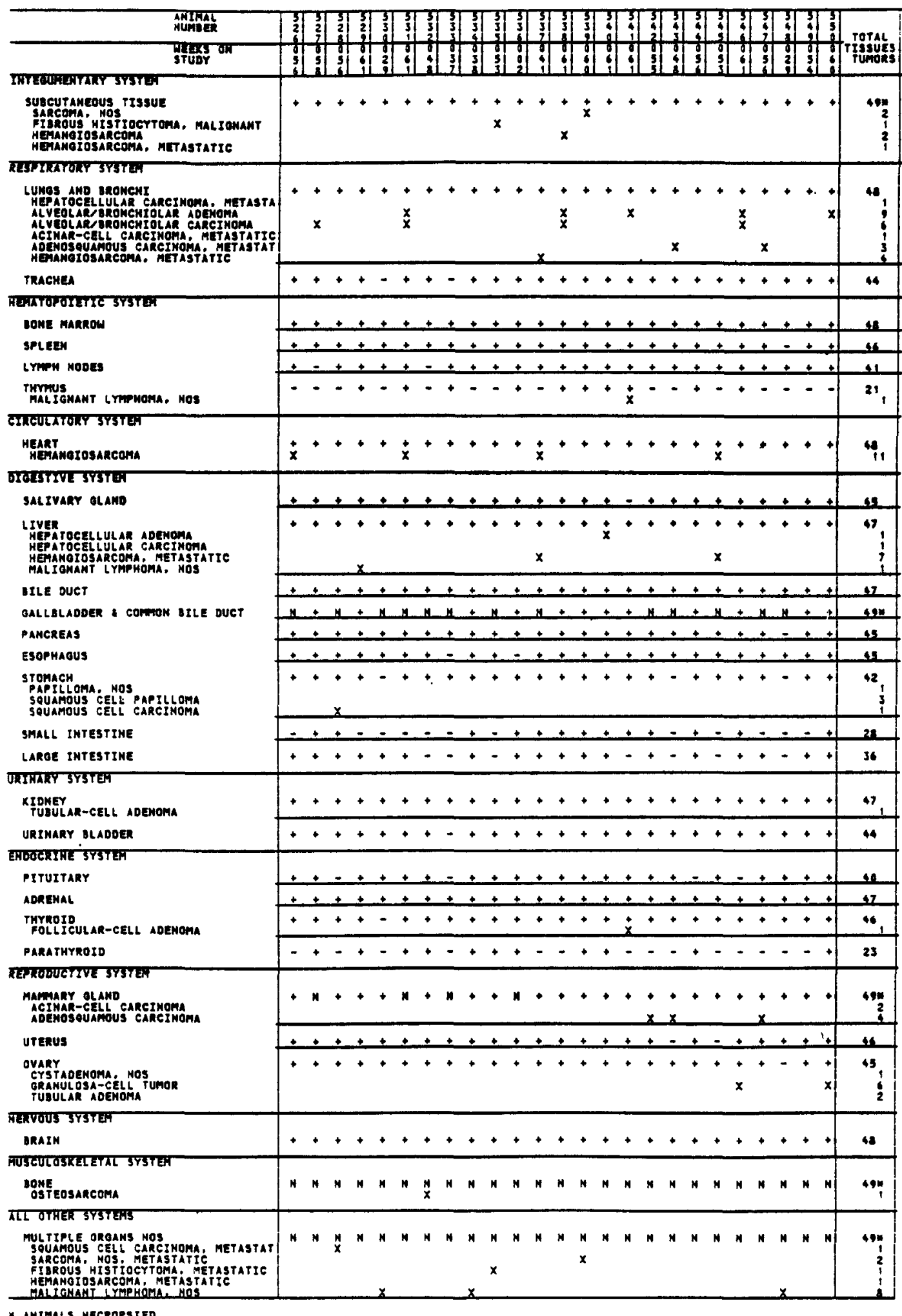


TABLE A4. INDIVIDUAL ANMAL TUMOR PATHOLOGY OF FEMALE MICE IN THE SIXTY-ONE-WEEK INHALATION STUDY OF 1,3-BUTADIENE : HIGH DOSE

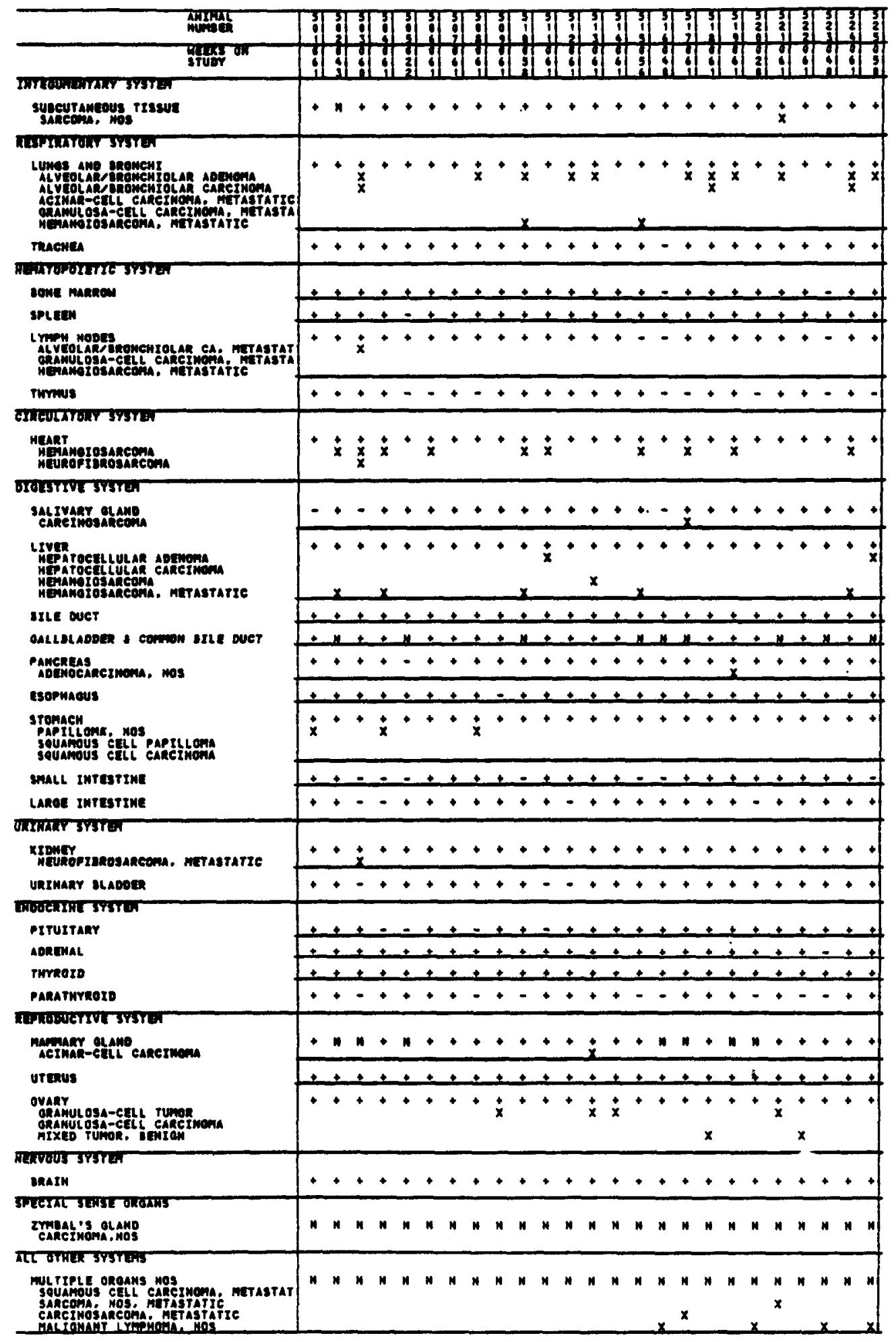


TABLE A4. INDIVIDUAL ANIMAL TUMOR PATHOLOGY OF FEMALE MICE : HIGH DOSE (Continued)

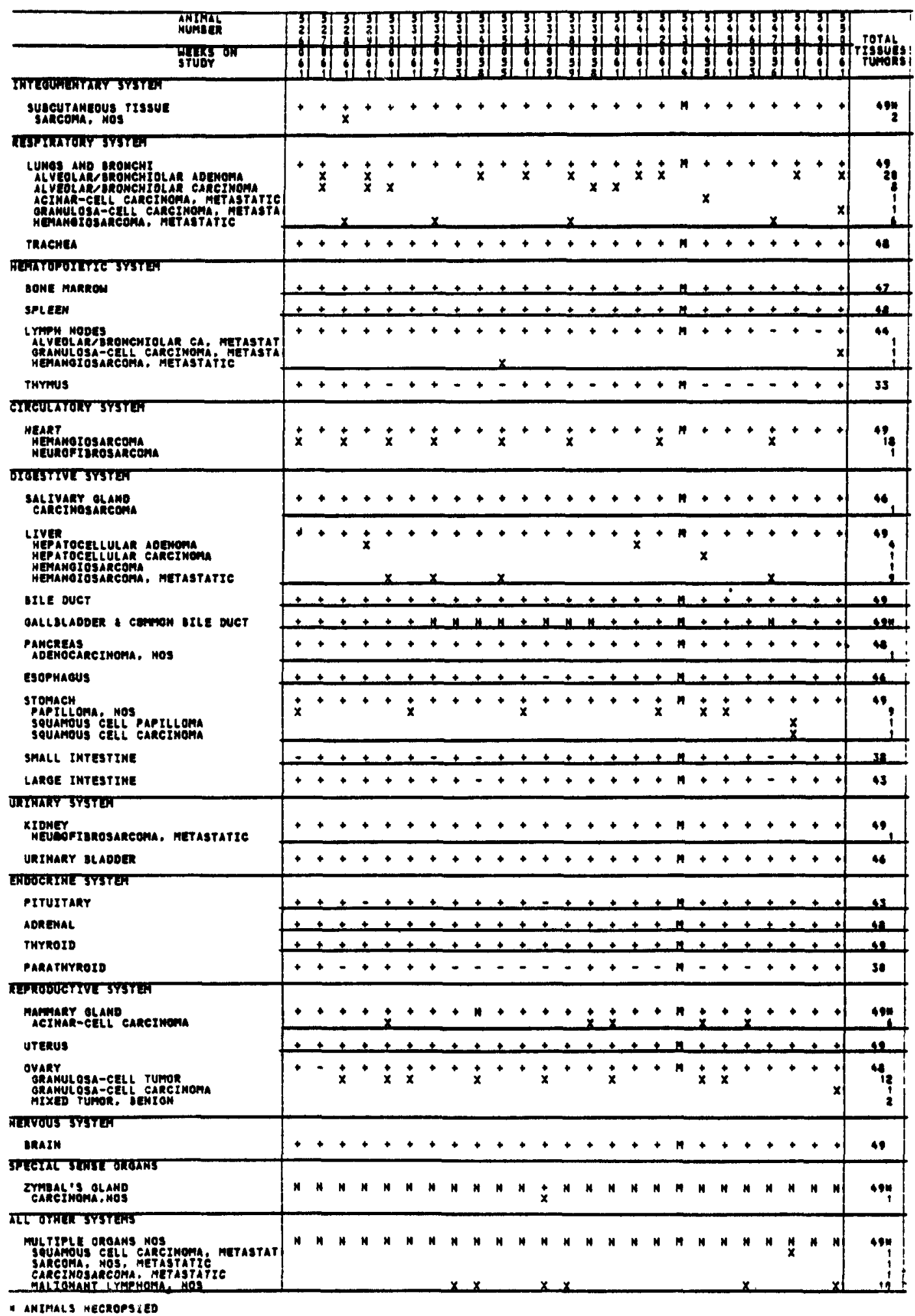




\section{APPENDIX B}

\section{SUMMARY OF THE INCIDENCE OF NONNEOPLASTIC}

LESIONS IN MICE IN THE SIXTY-ONE-WEEK INHALATION

STUDIES OF 1,3-BUTADIENE 
TABLE B1. SUMMARY OF THE INCIDENCE OF NONNEOPLASTIC LESIONS IN MALE MICE IN THE SIXTY.ONE.WEEK INHALATION STUDY OF 1,3-BUTADIENE

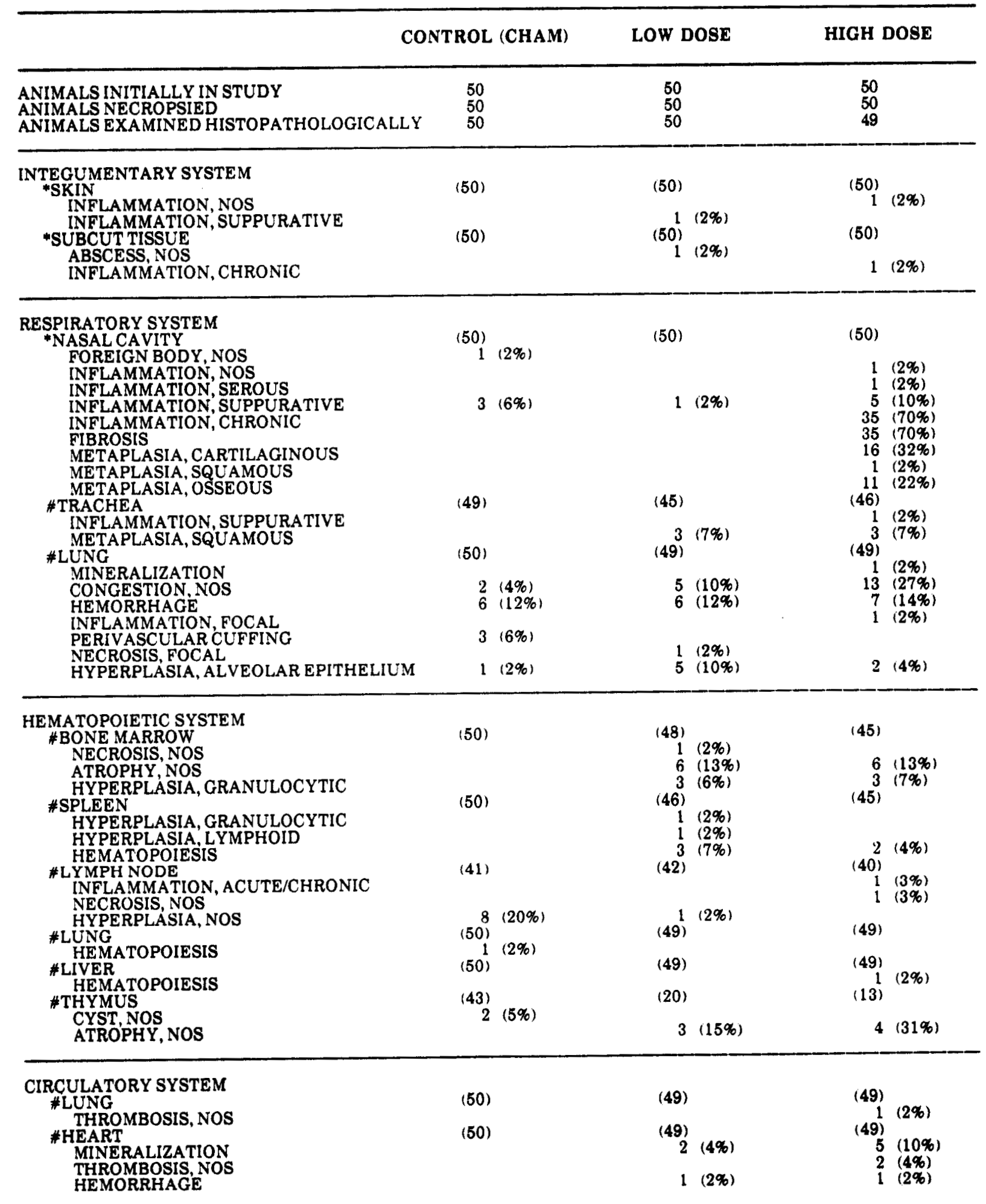


TABLE B1. SUMMARY OF THE INCIDENCE OF NONNEOPLASTIC LESIONS IN MALE MICE IN THE SIXTY-ONE-WEEK INHALATION STUDY OF 1,3-BUTADIENE (Continued)

\begin{tabular}{|c|c|c|c|c|}
\hline & CONTROL (CHAM) & LOW DOSE & HIGH I & DOSE \\
\hline $\begin{array}{l}\text { CIRCULATORY SYSTEM (Continued) } \\
\text { FIBROSIS } \\
\text { DEGENERATION, NOS } \\
\text { NECROSIS, NOS } \\
\text { NECROSIS, FOCAL } \\
\text { HYPERPLASIA, ATYPICAL }\end{array}$ & $1(2 \%)$ & $\begin{array}{ll}1 & (2 \%) \\
5 & (10 \%)\end{array}$ & $\begin{array}{l}2 \\
1 \\
2\end{array}$ & $\begin{array}{l}(4 \%) \\
(2 \%) \\
(4 \%)\end{array}$ \\
\hline $\begin{array}{l}\text { DIGESTIVE SYSTEM } \\
\text { "TOOTH } \\
\text { NECROSIS, NOS } \\
\text { \#SALIVARY GLAND } \\
\text { INFLAMMATION, NOS } \\
\text { \#LIVER } \\
\text { HEMORRHAGE } \\
\text { HEMATOMA, NOS } \\
\text { DEGENERATION, NOS } \\
\text { NECROSIS, NOS } \\
\text { NECROSIS, FOCAL } \\
\text { NECROSIS, CENTRAL } \\
\text { EOSINOPHILIC CYTO CHANGE } \\
\text { CLEAR-CELL CHANGE } \\
\text { \#LIVER/PERIPORTAL } \\
\text { FIBROSIS } \\
\text { \#PANCREAS } \\
\text { INFLAMMATION, NOS } \\
\text { ATROPHY, NOS } \\
\text { \#ESOPHAGUS } \\
\text { DILATATION, NOS } \\
\text { \#GLANDULAR STOMACH } \\
\text { ULCER, NOS } \\
\text { INFLAMMATION, SUPPURATIVE } \\
\text { \#FORESTOMACH } \\
\text { ULCER, NOS } \\
\text { INFLAMMATION, FOCAL } \\
\text { INFLAMMATION, SUPPURATIVE } \\
\text { INFLAMMATION, CHRONIC } \\
\text { HYPERPLASIA, EPITHELIAL } \\
\text { HYPERKERATOSIS }\end{array}$ & 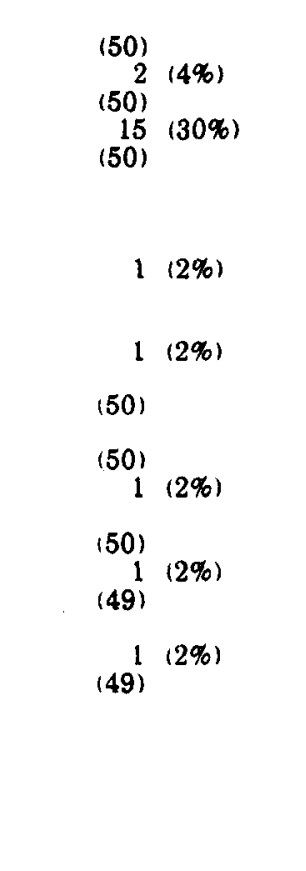 & $\begin{aligned}(50) & \\
(47) & \\
4 & (9 \%) \\
(49) & \\
7 & (14 \%) \\
1 & (2 \%) \\
1 & (2 \%) \\
5 & (10 \%) \\
2 & (4 \%) \\
1 & (2 \%) \\
& \\
(49) & \\
1 & (2 \%) \\
(46) & \\
& \\
(47) & \\
(40) & \\
& \\
(40) & \end{aligned}$ & $\begin{array}{r}(50) \\
(49) \\
1 \\
149) \\
4 \\
2 \\
2 \\
5 \\
3 \\
\\
1 \\
149) \\
(46) \\
2 \\
27 \\
(47) \\
(44) \\
1 \\
(44) \\
1 \\
1 \\
1 \\
1 \\
7 \\
1\end{array}$ & $\begin{array}{l} \\
(2 \%) \\
(8 \%) \\
(4 \%) \\
(10 \%) \\
(6 \%) \\
(2 \%) \\
\\
(4 \%) \\
\\
(2 \%) \\
(2 \%) \\
(2 \%) \\
(2 \%) \\
(2 \%) \\
(16 \%) \\
(2 \%)\end{array}$ \\
\hline $\begin{array}{l}\text { URINARY SYSTEM } \\
\text { \# KIDNEY } \\
\text { HEMORRHAGE } \\
\text { PYELONEPHRITIS, NOS } \\
\text { INFLAMMATION, NOS } \\
\text { PYELONEPHRITIS, ACUTE } \\
\text { GLOMERULONEPHRITIS, CHRONIC } \\
\text { INFARCT, NOS } \\
\text { \# KIDNEY/GLOMERULUS } \\
\text { MINERALIZATION } \\
\text { \# KIDNEY/PELVIS } \\
\text { INFLAMMATION, SUPPURATIVE } \\
\text { \#URINARY BLADDER } \\
\text { INFLAMMATION, SUPPURATIVE } \\
\text { HYPERPLASIA, EPITHELIAL }\end{array}$ & $\begin{aligned}(50) & \\
1 & (2 \%) \\
42 & (84 \%) \\
1 & (2 \%) \\
(50) & \\
(50) & \\
(49) & \end{aligned}$ & $\begin{aligned}(48) & \\
1 & (2 \%) \\
8 & (17 \%) \\
1 & (2 \%) \\
(48) & \\
(48) & \\
(40) & \\
1 & (3 \%)\end{aligned}$ & $\begin{array}{r}2 \\
2 \\
1 \\
148) \\
1 \\
(48) \\
1 \\
(42) \\
1 \\
3\end{array}$ & $\begin{array}{l}(4 \%) \\
(4 \%) \\
(2 \%) \\
(2 \%) \\
(2 \%) \\
(2 \%) \\
(7 \%)\end{array}$ \\
\hline $\begin{array}{l}\text { ENDOCRINE SYSTEM } \\
\text { \#ADRENAL/CAPSULE } \\
\text { HYPERPLASIA, NOS } \\
\text { \#ADRENALCORTEX } \\
\text { HYPERTROPHY, NOS } \\
\text { HYPERPLASIA, NOS } \\
\text { \#THYROID } \\
\text { ECTOPIA } \\
\text { CYST, NOS } \\
\text { INFLAMMATION, NOS } \\
\text { \#PARATHYROID } \\
\text { CYST, NOS }\end{array}$ & $\begin{aligned}(49) & \\
(49) & \\
1 & (2 \%) \\
(50) & \\
1 & (2 \%) \\
1 & (2 \%) \\
1 & (2 \%) \\
(39) & \\
1 & (3 \%)\end{aligned}$ & $\begin{aligned}(48) & \\
1 & (2 \%) \\
(48) & (8 \%)\end{aligned}$ & $\begin{array}{r}(46) \\
1 \\
(46) \\
1 \\
(47) \\
1 \\
(25)\end{array}$ & $\begin{array}{l}(2 \%) \\
(2 \%) \\
(2 \%)\end{array}$ \\
\hline
\end{tabular}


TABLE B1. SUMMARY OF THE INCIDENCE OF NONNEOPLASTIC LESIONS IN MALE MICE IN THE SIXTY-ONE-WEEK INHALATION STUDY OF 1,3-BUTADIENE (Continued)

\begin{tabular}{|c|c|c|c|}
\hline & CONTROL (CHAM) & LOW DOSE & HIGH DOSE \\
\hline $\begin{array}{l}\text { REPRODUCTIVE SYSTEM } \\
\text { *PREPUTIAL GLAND } \\
\text { CYST, NOS } \\
\text { INFLAMMATION, NOS } \\
\text { ABSCESS, NOS } \\
\text { "SEMINAL VESICLE } \\
\text { DILATATION, NOS } \\
\text { INFLAMMATION, SUPPURATIVE } \\
\text { \#TESTIS } \\
\text { INFLAMMATION, NOS } \\
\text { ATROPHY, NOS }\end{array}$ & $\begin{aligned} &(50) \\
& 1(2 \%) \\
& 1(2 \%) \\
&(50) \\
&(50)\end{aligned}$ & $\begin{aligned}(50) & \\
1 & (2 \%) \\
3 & (6 \%) \\
(50) & \\
1 & (2 \%) \\
(47) & \\
19 & (40 \%)\end{aligned}$ & $\begin{aligned}(50) & \\
1 & (2 \%) \\
& \\
(50) & \\
1 & (2 \%) \\
2 & (4 \%) \\
(48) & \\
1 & (2 \%) \\
11 & (23 \%)\end{aligned}$ \\
\hline $\begin{array}{l}\text { NERVOUS SYSTEM } \\
\text { \#BRAIN } \\
\text { HEMORRHAGE } \\
\text { CORPORA AMYLACEA } \\
\text { *OLFACTORY SENSORY EPITHELIUM } \\
\text { ATROPHY, NOS } \\
\text { ATROPHY, FOCAL }\end{array}$ & $\begin{array}{r}(50) \\
19 \quad(38 \%) \\
(50)\end{array}$ & $\begin{aligned}(48) & \\
1 & (2 \%) \\
8 & (17 \%) \\
(50) & \end{aligned}$ & $\begin{aligned}(49) & \\
1 & (2 \%) \\
2 & (4 \%) \\
(50) & \\
25 & (50 \%) \\
7 & (14 \%)\end{aligned}$ \\
\hline $\begin{array}{l}\text { SPECIAL SENSE CRGANS } \\
\text { "EYE } \\
\text { MICROPHTHALMIA } \\
\text { "LACRIMAL APPARATUS } \\
\text { HYPERPLASIA, EPITHELIAL }\end{array}$ & $\begin{array}{l}(50) \\
(50)\end{array}$ & $\begin{array}{l}(50) \\
(50)\end{array}$ & $\begin{array}{rr}(50) & \\
1 & (2 \%) \\
(50) & \\
1 & (2 \%)\end{array}$ \\
\hline \multicolumn{4}{|l|}{$\begin{array}{l}\text { MUSCULOSKELETAL SYSTEM } \\
\text { NONE }\end{array}$} \\
\hline $\begin{array}{l}\text { BODY CAVITIES } \\
\text { *MEDIASTINUM } \\
\text { HEMATOMA, NOS }\end{array}$ & $(50)$ & $\stackrel{(50)}{1}(2 \%)$ & (50) \\
\hline $\begin{array}{l}\text { ALL OTHER SYSTEMS } \\
\text { * MULTIPLE ORGANS } \\
\text { MINERALIZATION }\end{array}$ & $(50)$ & $(50)$ & $\stackrel{(50)}{1}(2 \%)$ \\
\hline $\begin{array}{l}\text { SPECIAL MORPHOLOGY SUMMARY } \\
\text { NO LESION REPORTED } \\
\text { AUTONECROPSYHISTO PERF } \\
\text { AUTONECROPSY } / \text { NO HISTO }\end{array}$ & 2 & 1 & $\begin{array}{l}1 \\
1\end{array}$ \\
\hline
\end{tabular}

\# NUMBER OF ANIMALS WITH TISSUE EXAMINED MICROSCOPICALLY

* NUMBER OF ANIMALS NECROPSIED 
TABLE B2. SUMMARY OF THE INCIDENCE OF NONNEOPLASTIC LESIONS IN FEMALE MICE IN THE SIXTY-ONE-WEEK INHALATION STUDY OF 1,3-BUTADIENE

\begin{tabular}{|c|c|c|c|c|}
\hline $\mathrm{CO}$ & TROL (CHAM) & LOW DOSE & HIGH & DOSE \\
\hline $\begin{array}{l}\text { ANIMALS INITIALLY IN STUDY } \\
\text { ANIMALS MISSING } \\
\text { ANIMALS NECROPSIED } \\
\text { ANIMALS EXAMINED HISTOPATHOLOGICALLY }\end{array}$ & $\begin{array}{l}50 \\
50 \\
50\end{array}$ & $\begin{array}{l}50 \\
49 \\
49\end{array}$ & $\begin{array}{r}50 \\
1 \\
49 \\
49\end{array}$ & \\
\hline $\begin{array}{l}\text { INTEGUMENTARY SYSTEM } \\
\text { *SKIN } \\
\text { HYPERPLASIA, NOS } \\
\text { HYPERPLASIA, BASAL CELL }\end{array}$ & $(50)$ & (49) & $\begin{array}{r}\text { (49) } \\
1 \\
1\end{array}$ & $\begin{array}{l}(2 \%) \\
(2 \%)\end{array}$ \\
\hline $\begin{array}{l}\text { RESPIRATORY SYSTEM } \\
\text { "NASALCAVITY } \\
\text { INFLAMMATION, SUPPURATIVE } \\
\text { INFLAMMATION, CHRONIC } \\
\text { FIBROSIS } \\
\text { METAPLASIA, CARTILAGINOUS } \\
\text { METAPLASIA, OSSEOUS } \\
\text { *LARYNX } \\
\text { INFLAMMATION, SUPPURATIVE } \\
\text { METAPLASIA, SQUAMOUS } \\
\text { \#TRACHEA } \\
\text { INFLAMMATION, SUPPURATIVE } \\
\text { METAPLASIA, SQUAMOUS } \\
\text { \#LUNG } \\
\text { CONGESTION, NOS } \\
\text { EDEMA, NOS } \\
\text { HEMORRHAGE } \\
\text { PERIVASCULAR CUFFING } \\
\text { HEMOSIDEROSIS } \\
\text { HYPERPLASIA, ALVEOLAR EPITHELIUM } \\
\text { HISTIOCYTOSIS }\end{array}$ & $\begin{aligned}(50) & \\
1 & (2 \%) \\
(49) & \\
2 & (4 \%) \\
1 & (2 \%) \\
(49) & \\
5 & (10 \%) \\
1 & (2 \%) \\
3 & (6 \%) \\
36 & (73 \%)\end{aligned}$ & $\begin{aligned}(49) & \\
1 & (2 \%) \\
(44) & \\
& \\
(48) & \\
3 & (6 \%) \\
5 & (10 \%) \\
4 & (8 \%) \\
8 & (17 \%) \\
4 & (8 \%)\end{aligned}$ & $\begin{array}{r}(49) \\
1 \\
2 \\
2 \\
1 \\
2 \\
(49) \\
1 \\
(48) \\
\\
(49) \\
1 \\
13 \\
6 \\
1 \\
7 \\
3\end{array}$ & $\begin{array}{l}(2 \%) \\
(4 \%) \\
(4 \%) \\
(2 \%) \\
(4 \%) \\
(2 \%) \\
\\
(2 \%) \\
(27 \%) \\
(12 \%) \\
(2 \%) \\
(14 \%) \\
(6 \%)\end{array}$ \\
\hline $\begin{array}{l}\text { HEMATOPOIETIC SYSTEM } \\
\text { *MULTIPLE ORGANS } \\
\text { LEUKOCYTOSIS, NOS } \\
\text { HYPERPLASIA, LYMPHOID } \\
\text { *PERITONEAL CA VITY } \\
\text { HEMATOPOIESIS } \\
\text { \# BONE MARROW } \\
\text { FIBROSIS } \\
\text { ATROPHY, NOS } \\
\text { HYPERPLASIA, GRANULOCYTIC } \\
\text { \#SPLEEN } \\
\text { NECROSIS, NOS } \\
\text { HISTIOCYTOSIS } \\
\text { HYPERPLASIA, LMPHOID } \\
\text { HEMATOPOIESIS } \\
\text { \#LYMPH NODE } \\
\text { HYPERPLAYA, NOS } \\
\text { HISTIOCYTUSIS } \\
\text { ERYTHROPHAGOCYTOSIS } \\
\text { \#LUNG } \\
\text { LEUKOCYTOSIS, NOS } \\
\text { ERYTHROPHAGOCYTOSIS } \\
\text { \#LIVER } \\
\text { HEMATOPOIESIS } \\
\text { \#ADRENAL } \\
\text { HEMATOPOIESIS } \\
\text { \#THYMUS } \\
\text { NECROSIS, NOS } \\
\text { ATROPHY, NOS }\end{array}$ & 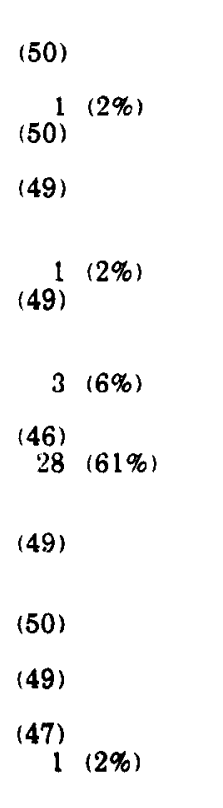 & $\begin{aligned}(49) & \\
1 & (2 \%) \\
(49) & \\
(48) & \\
1 & (2 \%) \\
1 & (2 \%) \\
3 & (6 \%) \\
(46) & \\
1 & (2 \%) \\
2 & (4 \%) \\
8 & (17 \%) \\
(41) & \\
3 & (7 \%) \\
1 & (2 \%) \\
1 & (2 \%) \\
(48) & (2 \%) \\
1 & (2 \%) \\
1 & (2 \%) \\
(47) & (2 \%) \\
1 & (2 \%) \\
(47) & (2 \%) \\
1 & (2 \%) \\
(21) & (10 \%) \\
2 & (10 \%)\end{aligned}$ & $\begin{array}{r}(49) \\
(49) \\
1 \\
(47) \\
2 \\
4 \\
(48)\end{array}$ & $\begin{array}{l}(2 \%) \\
(4 \%) \\
(9 \%)\end{array}$ \\
\hline
\end{tabular}


TABLE B2. SUMMARY OF THE INCIDENCE OF NONNEOPLASTIC LESIONS IN FEMALE MICE IN THE SIXTY-ONE-WEEK INHALATION STUDY OF 1,3-BUTADIENE (Continued)

\begin{tabular}{|c|c|c|c|c|}
\hline & CONTROL (CHAM) & LOW DOSE & HIGH & DOSE \\
\hline $\begin{array}{l}\text { CIRCULATORY SYSTEM } \\
\text { *MULTIPLE ORGANS } \\
\text { THROMBOSIS, NOS } \\
\text { \#LYMPH NODE } \\
\text { THROMBOSIS, NOS } \\
\text { \#LUNG } \\
\text { THROMBOSIS, NOS } \\
\text { EMBOLUS, SEPTIC } \\
\text { \#HEART } \\
\text { THROMBOSIS, NOS } \\
\text { HYPERPLASIA, ATYPICAL } \\
\text { \#OVARY } \\
\text { THROMBOSIS, NOS } \\
\text { \# ADRENAL CORTEX } \\
\text { THROMBOSIS, NOS }\end{array}$ & $\begin{array}{l}(50) \\
(46) \\
(49) \\
(49) \\
(49) \\
(49)\end{array}$ & $\begin{aligned}(49) & \\
& \\
(41) & \\
1 & (2 \%) \\
(48) & \\
2 & (4 \%) \\
1 & (2 \%) \\
(48) & \\
2 & (4 \%) \\
5 & (10 \%) \\
(45) & \\
1 & (2 \%) \\
(47) & \end{aligned}$ & $\begin{array}{r}(49) \\
1 \\
(44) \\
\\
(49) \\
1 \\
(49) \\
8 \\
(48) \\
1 \\
(48) \\
1\end{array}$ & $\begin{array}{l}(2 \%) \\
(2 \%) \\
(16 \%) \\
(2 \%) \\
(2 \%)\end{array}$ \\
\hline $\begin{array}{l}\text { DIGESTIVE SYSTEM } \\
\text { \#SALIVARY GLAND } \\
\text { INFLAMMATION, NOS } \\
\text { ATROPHY, FOCAL } \\
\text { HYPERPLASIA, NOS } \\
\text { \#LIVER } \\
\text { HEMORRHAGE } \\
\text { INFLAMMATION, NOS } \\
\text { DEGENERATION, NOS } \\
\text { NECROSIS, NOS } \\
\text { NECROSIS, FOCAL } \\
\text { EOSINOPHILIC CYTO CHANGE } \\
\text { ANGIECTASIS } \\
\text { \#BILE DUCT } \\
\text { DILATATION, NOS } \\
\text { HYPERPLASIA, NOS } \\
\text { \#PANCREAS } \\
\text { INFLAMMATION, NOS } \\
\text { NECROSIS, NOS } \\
\text { ATROPHY, NOS } \\
\text { \#FORESTOMACH } \\
\text { HYPERPLASIA, EPITHELIAL } \\
\text { HYPERKERATOSIS } \\
\text { *RECTUM } \\
\text { HEMORRHAGE }\end{array}$ & 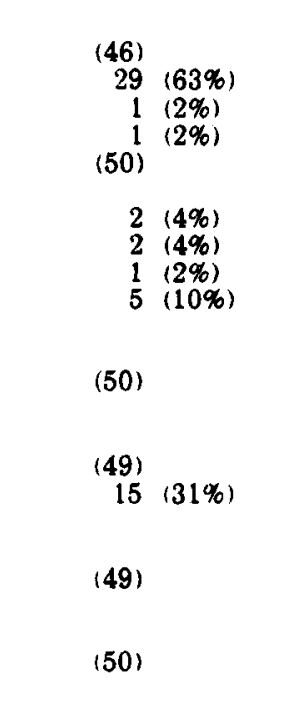 & $\begin{aligned}(45) & \\
6 & (13 \%) \\
& \\
(47) & \\
4 & (9 \%) \\
2 & (4 \%) \\
1 & (2 \%) \\
12 & (26 \%) \\
3 & (6 \%) \\
1 & (2 \%) \\
1 & (2 \%) \\
(47) & \\
1 & (2 \%) \\
1 & (2 \%) \\
(45) & \\
4 & (9 \%) \\
1 & (2 \%) \\
1 & (2 \%) \\
(42) & \\
5 & (12 \%) \\
1 & (2 \%) \\
(49) & \\
1 & (2 \%)\end{aligned}$ & $\begin{array}{r}(46) \\
13 \\
\\
(49) \\
3 \\
2 \\
5 \\
1 \\
1 \\
(49) \\
\\
\\
(48) \\
2 \\
1 \\
2 \\
(49) \\
9 \\
(49)\end{array}$ & $\begin{array}{l}(28 \%) \\
(6 \%) \\
(4 \%) \\
(10 \%) \\
(2 \%) \\
(2 \%)\end{array}$ \\
\hline $\begin{array}{l}\text { URINARY SYSTEM } \\
\text { \# KIDNEY } \\
\text { INFLAMMATION, NOS } \\
\text { PERIVASCULAR CUFFING } \\
\text { INFARCT, NOS } \\
\text { AMYLOIDOSIS } \\
\text { \# KIDNEY/TUBULE } \\
\text { PIGMENTATION, NOS } \\
\text { \#URINARY BLADDER } \\
\text { HEMORRHAGE } \\
\text { INFLAMMATION, NOS }\end{array}$ & $\begin{aligned}(49) & \\
41 & (84 \%) \\
1 & (2 \%) \\
1 & (2 \%) \\
(49) & \\
(45) & \end{aligned}$ & $\begin{aligned}(47) & \\
9 & (19 \%) \\
1 & (2 \%) \\
(47) & \\
2 & (4 \%) \\
(44) & \\
1 & (2 \%)\end{aligned}$ & $\begin{array}{r}(49) \\
13 \\
1 \\
(49) \\
(46) \\
1 \\
1\end{array}$ & $\begin{array}{l}(27 \%) \\
(2 \%) \\
(2 \%) \\
(2 \%)\end{array}$ \\
\hline $\begin{array}{l}\text { ENDOCRINE SYSTEM } \\
\text { \#PITUITARY } \\
\text { CYST, NOS } \\
\text { DEGENERATION, CYSTIC } \\
\text { \#ADRENAL } \\
\text { CYST, NOS } \\
\text { DEGENERATION, NOS } \\
\text { NECROSIS, CORTICAL } \\
\text { \#ADRENAL/CAPSULE } \\
\text { HYPERPLASIA, NOS }\end{array}$ & $\begin{array}{l}(45) \\
(49)\end{array}$ & $\begin{aligned}(40) & \\
1 & (3 \%) \\
1 & (3 \%) \\
(47) & \\
2 & (4 \%) \\
1 & (2 \%) \\
(47) & \\
26 & (53 \%)\end{aligned}$ & $\begin{array}{r}(43) \\
\\
(48) \\
1 \\
1 \\
1 \\
(48) \\
35\end{array}$ & $\begin{array}{l}(2 \%) \\
(2 \%) \\
(2 \%) \\
(73 \%)\end{array}$ \\
\hline
\end{tabular}


TABLE B2. SUMMARY OF THE INCIDENCE OF NONNEOPLASTIC LESIONS IN FEMALE MICE IN THE SIXTY.ONE-WEEK INHALATION STUDY OF 1,3-BUTADIENE (Continued)

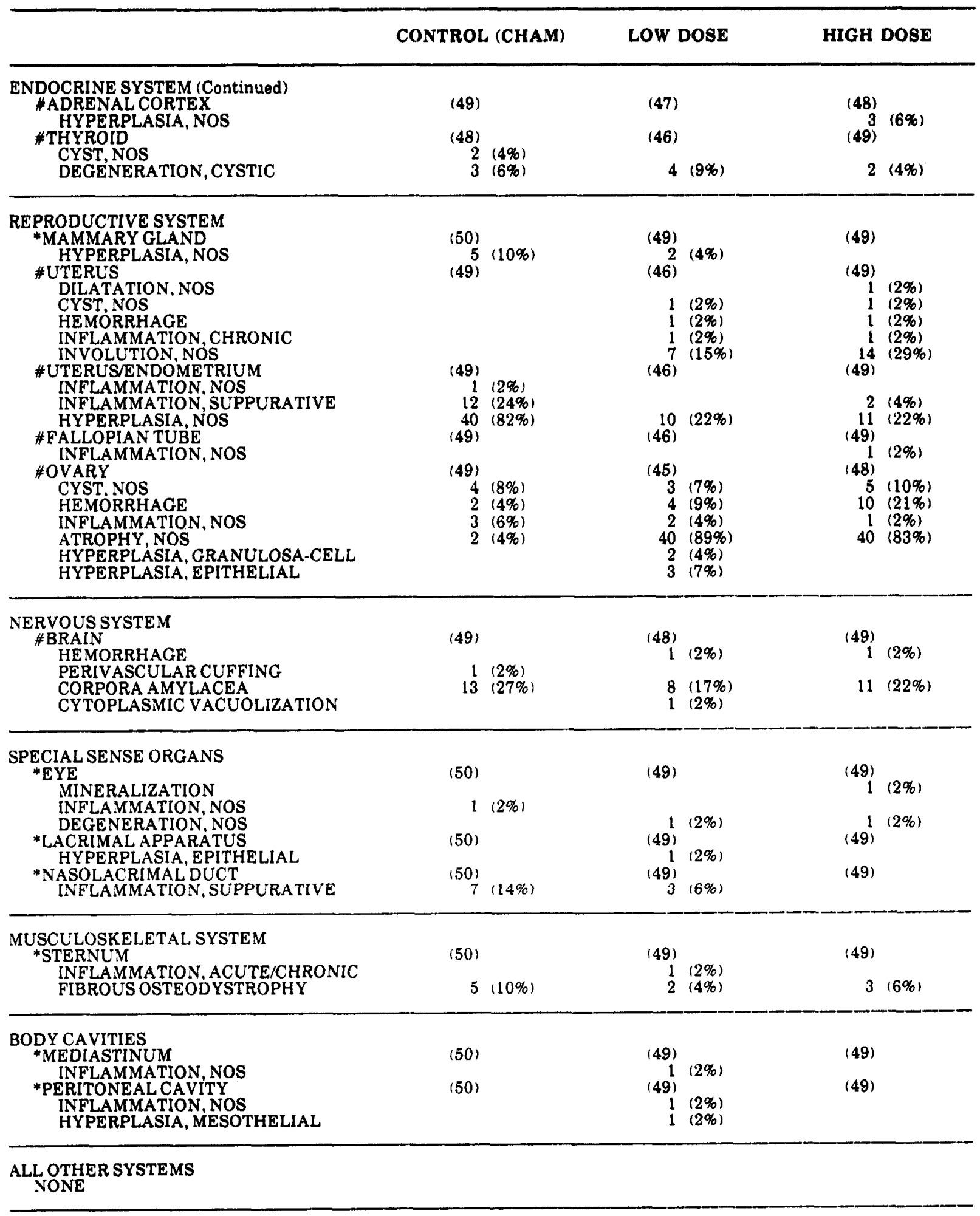


TABLE B2. SUMMARY OF THE INCIDENCE OF NONNEOPLASTIC LESIONS IN FEMALE MICE IN THE SIXTY.ONE.WEEK INHALATION STUDY OF 1,3-BUTADIENE (Continued)

\begin{tabular}{|c|c|c|c|}
\hline & CONTROL (CHAM) & LOW DOSE & HIGH DOSE \\
\hline $\begin{array}{l}\text { SPECIAL MORPHOLOGY SUMMARY } \\
\text { NO LESION REPORTED } \\
\text { ANIMAL MISSING/NO NECROPSY } \\
\text { ACCIDENTAL DEATH } \\
\text { AUTO/NECROPSY/HISTO PERF }\end{array}$ & & $\begin{array}{l}1 \\
1 \\
1\end{array}$ & 1 \\
\hline
\end{tabular}

\# NUMBER OF ANIMALS WITH TISSUE EXAMINED MICROSCOPICALLY

* NUMBER OF ANIMALS NECROPSIED 


\section{APPENDIX C}

\section{ANALYSES OF PRIMARY TUMORS IN MICE \\ IN THE SIXTY-ONE-WEEK INHALATION STUDIES OF \\ 1,3-BUTADIENE}


TABLE C1. ANALYSIS OF PRIMARY TUMORS IN MALE MICE IN THE SIXTY-ONE-WEEK INHALATION STUDY OF 1,3-BUTADIENE

\begin{tabular}{|c|c|c|c|}
\hline & Control & 625 ppm & l,260 ppm \\
\hline $\begin{array}{l}\text { Lung: Alveolar/Bronchiolar Adeno } \\
\text { Overall Rates (a) } \\
\text { Adjusted Rates (b) } \\
\text { Terminal Rates (c) } \\
\text { Life Table Tests (d) } \\
\text { Cochran-Armitage Trend Test (d) } \\
\text { Fisher Exact Tests }\end{array}$ & $\begin{array}{l}2 / 50(4 \%) \\
4.1 \% \\
2 / 49(4 \%) \\
\mathrm{P}<0.001 \\
\mathrm{P}=0.010\end{array}$ & $\begin{array}{l}12 / 49(24 \%) \\
72.3 \% \\
7 / 11(64 \%) \\
\mathrm{P}<0.001 \\
\mathrm{P}=0.003\end{array}$ & $\begin{array}{l}11 / 49(22 \%) \\
75.0 \% \\
4 / 7(57 \%) \\
P<0.001 \\
P=0.007\end{array}$ \\
\hline $\begin{array}{l}\text { Lung: Alveolar/Bronchiolar Carcir } \\
\text { Overall Rates (a) } \\
\text { Adjusted Rates (b) } \\
\text { Terminal Rates (c) } \\
\text { Life Table Tests (d) } \\
\text { Cochran-Armitage Trend Test (d) } \\
\text { Fisher Exact Tests }\end{array}$ & $\begin{array}{l}0 / 50(0 \%) \\
0.0 \% \\
0 / 49(0 \%) \\
P<0.001 \\
P=0.016\end{array}$ & $\begin{array}{l}2 / 49(4 \%) \\
18.2 \% \\
2 / 11(18 \%) \\
P=0.018 \\
P=0.242\end{array}$ & $\begin{array}{l}5 / 49(10 \%) \\
47.6 \% \\
3 / 7(43 \%) \\
P<0.001 \\
P=0.027\end{array}$ \\
\hline $\begin{array}{l}\text { Lung: Alveolar/Bronchiolar Adeno } \\
\text { Overall Rates (a) } \\
\text { Adjusted Rates (b) } \\
\text { Terminal Rates (c) } \\
\text { Life Table Tests (d) } \\
\text { Cochran-Armitage Trend Test (d) } \\
\text { Fisher Exact Tests. }\end{array}$ & $\begin{array}{l}1 \mathrm{a} \\
2 / 50(4 \%) \\
4.1 \% \\
2 / 49(4 \%) \\
P<0.001 \\
P<0.001\end{array}$ & $\begin{array}{l}14 / 49(29 \%) \\
86.2 \% \\
9 / 11(82 \%) \\
P<0.001 \\
P<0.001\end{array}$ & $\begin{array}{l}15 / 49(31 \%) \\
92.4 \% \\
6 / 7(86 \%) \\
P<0.001 \\
P<0.001\end{array}$ \\
\hline $\begin{array}{l}\text { Hematopoietic System: Lymphoma } \\
\text { Overall Rates (a) } \\
\text { Adjusted Rates (b) } \\
\text { Terminal Rates (c) } \\
\text { Life Table Tests (d) } \\
\text { Cochran-Armitage Trend Test (d) } \\
\text { Fisher Exact Tests }\end{array}$ & $\begin{array}{l}0 / 50(0 \%) \\
0.0 \% \\
0 / 49(0 \%) \\
P<0.001 \\
P<0.001\end{array}$ & $\begin{array}{l}23 / 50(46 \%) \\
59.4 \% \\
2 / 11(18 \%) \\
\mathrm{P}<0.001 \\
\mathrm{P}<0.001\end{array}$ & $\begin{array}{l}29 / 50(58 \%) \\
75.5 \% \\
1 / 7(14 \%) \\
P<0.001 \\
P<0.001\end{array}$ \\
\hline $\begin{array}{l}\text { Heart: Hemangiosarcoma } \\
\text { Overall Rates (a) } \\
\text { Adjusted Rates (b) } \\
\text { Terminal Rates (c) } \\
\text { Life Table Tests (d) } \\
\text { Cochran-Armitage Trend Test (d) } \\
\text { Fisher Exact Tests }\end{array}$ & $\begin{array}{l}0 / 50(0 \%) \\
0.0 \% \\
0 / 49(0 \%) \\
P<0.001 \\
P=0.032\end{array}$ & $\begin{array}{l}16 / 49(33 \%) \\
57.5 \% \\
2 / 11(18 \%) \\
\mathrm{P}<0.001 \\
\mathrm{P}<0.001\end{array}$ & $\begin{array}{l}7 / 49(14 \%) \\
57.3 \% \\
3 / 7(43 \%) \\
\mathrm{P}<0.001 \\
\mathrm{P}=0.006\end{array}$ \\
\hline $\begin{array}{l}\text { Circulatory System: Hemangiosarc } \\
\text { Overall Rates (a) } \\
\text { Adjusted Rates (b) } \\
\text { Terminal Rates (c) } \\
\text { Life Table Tests (d) } \\
\text { Cochran-Armitage Trend Test (d) } \\
\text { Fisher Exact Tests }\end{array}$ & $\begin{array}{l}0 / 50(0 \%) \\
0.0 \% \\
0 / 49(0 \%) \\
P<0.001 \\
P=0.020\end{array}$ & $\begin{array}{l}16 / 50(32 \%) \\
57.5 \% \\
2 / 11(18 \%) \\
P<0.001 \\
P<0.001\end{array}$ & $\begin{array}{l}8 / 50(16 \%) \\
62.6 \% \\
3 / 7(43 \%) \\
P<0.001 \\
P=0.003\end{array}$ \\
\hline $\begin{array}{l}\text { Liver: Hepatocellular Adenoma } \\
\text { Overall Rates (a) } \\
\text { Adjusted Rates (b) } \\
\text { Terminal Rates (c) } \\
\text { Life Table Tests (d) } \\
\text { Cochran-Armitage Trend Test (d) } \\
\text { Fisher Exact Tests }\end{array}$ & $\begin{array}{l}5 / 50(10 \%) \\
10.2 \% \\
5 / 49(10 \%) \\
P=0.230 \\
P=0.085 \mathrm{~N}\end{array}$ & $\begin{array}{l}4 / 49(8 \%) \\
26.5 \% \\
2 / 11(18 \%) \\
P=0.078 \\
P=0.513 \mathrm{~N}\end{array}$ & $\begin{array}{l}1 / 49(2 \%) \\
14.3 \% \\
1 / 7(14 \%) \\
P=0.627 \\
P=0.107 \mathrm{~N}\end{array}$ \\
\hline
\end{tabular}


TABLE C1. ANALYSIS OF PRIMARY TUMORS IN MALE MICE IN THE SIXTY-ONE-WEEK INHALATION STUDY OF 1,3-BUTADIENE (Continued)

\begin{tabular}{|c|c|c|c|}
\hline & Control & 625 ppm & $1,250 \mathrm{ppm}$ \\
\hline $\begin{array}{l}\text { Liver: Hepatocellular Carcinoma } \\
\text { Overall Rates (a) } \\
\text { Adjusted Rates (b) } \\
\text { Terminal Rates (c) } \\
\text { Life Table Tests (d) } \\
\text { Cochran-Armitage Trend Test (d) } \\
\text { Fisher Exact Tests }\end{array}$ & $\begin{array}{l}3 / 50(6 \%) \\
6.1 \% \\
3 / 49(6 \%) \\
P=0.262 \\
P=0.229 \mathrm{~N}\end{array}$ & $\begin{array}{l}2 / 49(4 \%) \\
15.2 \% \\
1 / 11(9 \%) \\
P=0.269 \\
P=0.510 \mathrm{~N}\end{array}$ & $\begin{array}{l}1 / 49(2 \%) \\
9.1 \% \\
0 / 7(0 \%) \\
P=0.534 \\
P=0.316 \mathrm{~N}\end{array}$ \\
\hline $\begin{array}{l}\text { Liver: Hepatocellular Adenoma or } \\
\text { Overall Rates (a) } \\
\text { Adjusted Rates (b) } \\
\text { Terminal Rates (c) } \\
\text { Life Table Tests (d) } \\
\text { Cochran-Armitage Trend Test (d) } \\
\text { Fisher Exact Tests }\end{array}$ & $\begin{array}{l}8 / 50(16 \%) \\
16.3 \% \\
8 / 49(16 \%) \\
P=0.114 \\
P=0.040 \mathrm{~N}\end{array}$ & $\begin{array}{l}6 / 49(12 \%) \\
39.0 \% \\
3 / 11(27 \%) \\
P=0.027 \\
P=0.403 N\end{array}$ & $\begin{array}{l}2 / 49(4 \%) \\
22.1 \% \\
1 / 7(14 \%) \\
P=0.424 \\
P=0.049 \mathrm{~N}\end{array}$ \\
\hline $\begin{array}{l}\text { Forestomach: All Papilloma } \\
\text { Overall Rates (a) } \\
\text { Adjusted Rates (b) } \\
\text { Terminal Rates (c) } \\
\text { Life Table Tests (d) } \\
\text { Cochran-Armitage Trend Test (d) } \\
\text { Fisher Exact Tests }\end{array}$ & $\begin{array}{l}0 / 49(0 \%) \\
0.0 \% \\
0 / 48(0 \%) \\
P=0.036 \\
P=0.568\end{array}$ & $\begin{array}{l}5 / 40(13 \%) \\
45.5 \% \\
5 / 11(45 \%) \\
P<0.001 \\
P=0.016\end{array}$ & $\begin{array}{l}0 / 44(0 \%) \\
0.0 \% \\
0 / 7(0 \%) \\
\text { (e) } \\
\text { (e) }\end{array}$ \\
\hline $\begin{array}{l}\text { Forestomach: Squamous Cell Papi } \\
\text { Overall Rates (a) } \\
\text { Adjusted Rates (b) } \\
\text { Terminal Rates (c) } \\
\text { Life Table Tests (d) } \\
\text { Cochran-Armitage Trend Test (d) } \\
\text { Fisher Exact Tests }\end{array}$ & $\begin{array}{l}\mathrm{ma} \\
0 / 49(0 \%) \\
0.0 \% \\
0 / 48(0 \%) \\
P=0.032 \\
P=0.354\end{array}$ & $\begin{array}{l}4 / 40(10 \%) \\
26.2 \% \\
2 / 11(18 \%) \\
P=0.001 \\
P=0.037\end{array}$ & $\begin{array}{l}1 / 44(2 \%) \\
7.1 \% \\
0 / 7(0 \%) \\
P=0.248 \\
P=0.473\end{array}$ \\
\hline $\begin{array}{l}\text { Forestomach: All Papilloma or Car } \\
\text { Overall Rates (a) } \\
\text { Adjusted Rates (b) } \\
\text { Terminal Rates (c) } \\
\text { Life Table Tests (d) } \\
\text { Cochran-Armitage Trend Test (d) } \\
\text { Fisher Exact Tests }\end{array}$ & $\begin{array}{l}0 / 49(0 \%) \\
0.0 \% \\
0 / 48(0 \%) \\
P=0.006 \\
P=0.363\end{array}$ & $\begin{array}{l}7 / 40(18 \%) \\
50.8 \% \\
5 / 11(45 \%) \\
P<0.001 \\
P=0.003\end{array}$ & $\begin{array}{l}1 / 44(2 \%) \\
7.1 \% \\
0 / 7(0 \%) \\
P=0.248 \\
P=0.473\end{array}$ \\
\hline $\begin{array}{l}\text { Preputial Gland: Squamous Cell C } \\
\text { Overall Rates (a) } \\
\text { Adjusted Rates (b) } \\
\text { Terminal Rates (c) } \\
\text { Life Table Tests (d) } \\
\text { Cochran-Armitage Trend Test (d) } \\
\text { Fisher Exact Tests }\end{array}$ & $\begin{array}{l}0 / 50(0 \%) \\
0.0 \% \\
0 / 49(0 \%) \\
P=0.017 \\
P=0.378\end{array}$ & $\begin{array}{l}3 / 50(6 \%) \\
21.9 \% \\
2 / 11(18 \%) \\
P=0.005 \\
P=0.121\end{array}$ & $\begin{array}{l}1 / 50(2 \%) \\
14.3 \% \\
1 / 7(14 \%) \\
P=0.128 \\
P=0.500\end{array}$ \\
\hline $\begin{array}{l}\text { Preputial Gland: All Carcinoma } \\
\text { Overall Rates (a) } \\
\text { Adjusted Rates (b) } \\
\text { Terminal Rates (c) } \\
\text { Life Table Tests (d) } \\
\text { Cochran-Armitage Trend Test (d) } \\
\text { Fisher Exact Tests }\end{array}$ & $\begin{array}{l}0 / 50(0 \%) \\
0.0 \% \\
0 / 49(0 \%) \\
P=0.001 \\
P=0.202\end{array}$ & $\begin{array}{l}3 / 50(6 \%) \\
21.9 \% \\
2 / 11(18 \%) \\
P=0.005 \\
P=0.121\end{array}$ & $\begin{array}{l}2 / 50(4 \%) \\
28.6 \% \\
2 / 7(29 \%) \\
P=0.003 \\
P=0.247\end{array}$ \\
\hline
\end{tabular}

(a) Number of tumor-bearing animals/number of animals examined at the site

(b) Kaplan-Meier estimated tumor incidence at the end of the study after adjusting for intercurrent mortality (c) Observed tumor incidence at terminal kill

(d) Beneath the control incidence are the $\mathrm{P}$ values associated with the trend test. Beneath the dosed group incidence are the $P$ values corresponding to pairwise comparisons between that dosed group and the controls. The life table analysis regards tumors in animals dying prior to terminal kill as being (directly or indirectly) the cause of death. The Cochran-Armitage and Fisher's exact test compare directly the overall incidence rates. A negative trend or lower incidence in a dosed group is indicated by $(\mathrm{N})$.

(e) No $P$ value is presented because no tumors were observed in the 1,250-ppm and control groups. 
TABLE C2. ANALYSIS OF PRIMARY TUMORS IN FEMALE MICE IN THE SIXTY-ONE-WEEK INHALATION STUDY OF 1,3-BUTADIENE

\begin{tabular}{|c|c|c|c|}
\hline & Control & 625 ppm & 1,250 ppm \\
\hline $\begin{array}{l}\text { Lung: Alveolar/Bronchiolar Adeno } \\
\text { Overall Rates (a) } \\
\text { Adjusted Rates (b) } \\
\text { Terminal Rates (c) } \\
\text { Life Table Tests (d) } \\
\text { Cochran-Armitage Trend Test (d) } \\
\text { Fisher Exact Tests }\end{array}$ & $\begin{array}{l}3 / 49(6 \%) \\
6.5 \% \\
3 / 46(7 \%) \\
P<0.001 \\
P<0.001\end{array}$ & $\begin{array}{l}9 / 48(19 \%) \\
48.1 \% \\
6 / 15(40 \%) \\
P<0.001 \\
P=0.056\end{array}$ & $\begin{array}{l}20 / 49(41 \%) \\
56.7 \% \\
15 / 30(50 \%) \\
P<0.001 \\
P<0.001\end{array}$ \\
\hline $\begin{array}{l}\text { Lung: Alveolar/Bronchiolar Carcir } \\
\text { Overall Rates (a) } \\
\text { Adjusted Rates (b) } \\
\text { Terminal Rates (c) } \\
\text { Life Table Tests (d) } \\
\text { Cochran-Armitage Trend Test (d) } \\
\text { Fisher Exact Tests }\end{array}$ & $\begin{array}{l}0 / 49(0 \%) \\
0.0 \% \\
0 / 46(0 \%) \\
P=0.001 \\
P=0.004\end{array}$ & $\begin{array}{l}6 / 48(13 \%) \\
36.7 \% \\
5 / 15(33 \%) \\
P<0.001 \\
P=0.012\end{array}$ & $\begin{array}{l}8 / 49(16 \%) \\
24.7 \% \\
6 / 30(20 \%) \\
P<0.001 \\
P=0.003\end{array}$ \\
\hline $\begin{array}{l}\text { Lung: Alveolar/Bronchiolar Adeno } \\
\text { Overall Rates (a) } \\
\text { Adjusted Rates (b) } \\
\text { Terminal Rates (c) } \\
\text { Life Table Tests (d) } \\
\text { Cochran-Armitage Trend Test (d) } \\
\text { Fisher Exact Tests }\end{array}$ & $\begin{array}{l}\mathrm{a} \\
3 / 49(6 \%) \\
6.5 \% \\
3 / 46(7 \%) \\
\mathrm{P}<0.001 \\
\mathrm{P}<0.001\end{array}$ & $\begin{array}{l}12 / 48(25 \%) \\
61.7 \% \\
8 / 15(53 \%) \\
P<0.001 \\
P=0.010\end{array}$ & $\begin{array}{l}23 / 49(47 \%) \\
63.6 \% \\
17 / 30(57 \%) \\
P<0.001 \\
P<0.001\end{array}$ \\
\hline $\begin{array}{l}\text { Hematopoietic System: Lymphoma } \\
\text { Overall Rates (a) } \\
\text { Adjusted Rates (b) } \\
\text { Terminal Rates (c) } \\
\text { Life Table Tests (d) } \\
\text { Cochran-Armitage Trend Test (d) } \\
\text { Fisher Exact Tests }\end{array}$ & $\begin{array}{l}1 / 50(2 \%) \\
2.2 \% \\
1 / 46(2 \%) \\
P=0.006 \\
P=0.006\end{array}$ & $\begin{array}{l}10 / 49(20 \%) \\
32.0 \% \\
3 / 15(20 \%) \\
P<0.001 \\
P=0.003\end{array}$ & $\begin{array}{l}10 / 49(20 \%) \\
22.9 \% \\
1 / 30(3 \%) \\
P=0.003 \\
P=0.003\end{array}$ \\
\hline $\begin{array}{l}\text { Heart: Hemangiosarcoma } \\
\text { Overail Rates (a) } \\
\text { Adjusted Rates (b) } \\
\text { Terminal Rates (c) } \\
\text { Life Table Tests (d) } \\
\text { Cochran-Armitage Trend Test (d) } \\
\text { Fisher Exact Tests }\end{array}$ & $\begin{array}{l}0 / 50(0 \%) \\
0.0 \% \\
0 / 46(0 \%) \\
P<0.001 \\
P<0.001\end{array}$ & $\begin{array}{l}11 / 48(23 \%) \\
40.6 \% \\
3 / 15(20 \%) \\
P<0.001 \\
P<0.001\end{array}$ & $\begin{array}{l}18 / 49(37 \%) \\
46.3 \% \\
10 / 30(33 \%) \\
P<0.001 \\
P<0.001\end{array}$ \\
\hline $\begin{array}{l}\text { Circulatory System: Hemangiosarc } \\
\text { Overall Rates (a) } \\
\text { Adjusted Rates (b) } \\
\text { Terminal Rates (c) } \\
\text { Life Table Tests (d) } \\
\text { Cochran-Armitage Trend Test (d) } \\
\text { Fisher Exact Tests }\end{array}$ & $\begin{array}{l}0 / 50(0 \%) \\
0.0 \% \\
0 / 46(0 \%) \\
P<0.001 \\
P<0.001\end{array}$ & $\begin{array}{l}13 / 49(27 \%) \\
50.5 \% \\
5 / 15(33 \%) \\
P<0.001 \\
P<0.001\end{array}$ & $\begin{array}{l}19 / 49(39 \%) \\
49.0 \% \\
11 / 30(37 \%) \\
\mathrm{P}<0.001 \\
\mathrm{P}<0.001\end{array}$ \\
\hline $\begin{array}{l}\text { Liver: Hepatocellular Adenoma } \\
\text { Overail Rates (a) } \\
\text { Adjusted Rates (b) } \\
\text { Terminal Rates (c) } \\
\text { Life Table Tests (d) } \\
\text { Cochran-Armitage Trend Test (d) } \\
\text { Fisher Exact Tests }\end{array}$ & $\begin{array}{l}0 / 50(0 \%) \\
0.0 \% \\
0 / 46(0 \%) \\
P=0.015 \\
P=0.025\end{array}$ & $\begin{array}{l}1 / 47(2 \%) \\
6.7 \% \\
1 / 15(7 \%) \\
P=0.278 \\
P=0.485\end{array}$ & $\begin{array}{l}4 / 49(8 \%) \\
12.1 \% \\
3 / 30(10 \%) \\
P=0.030 \\
P=0.056\end{array}$ \\
\hline
\end{tabular}


TABLE C2. ANALYSIS OF PRIMARY TUMORS IN FEMALE MICE IN THE SIXTY-ONE-WEEK INHALATION STUDY OF 1.3-BUTADIENE (Continued)

\begin{tabular}{|c|c|c|c|}
\hline & Control & 625 ppm & 1,250 ppm \\
\hline $\begin{array}{l}\text { Liver: Hepatocellular Adenoma or } \\
\text { Overall Rates (a) } \\
\text { Adjusted Rates (b) } \\
\text { Terminal Rates (c) } \\
\text { Life Table Tests (d) } \\
\text { Cochran-Armitage Trend Test (d) } \\
\text { Fisher Exact Tests }\end{array}$ & $\begin{array}{l}0 / 50(0 \%) \\
0.0 \% \\
0 / 46(0 \%) \\
P=0.009 \\
P=0.016\end{array}$ & $\begin{array}{l}2 / 47(4 \%) \\
13.3 \% \\
2 / 15(13 \%) \\
P=0.048 \\
P=0.232\end{array}$ & $\begin{array}{l}5 / 49(10 \%) \\
14.3 \% \\
3 / 30(10 \%) \\
P=0.015 \\
P=0.027\end{array}$ \\
\hline $\begin{array}{l}\text { Forestomach: Squamous Cell Papil } \\
\text { Overall Rates (a) } \\
\text { Adjusted Rates (b) } \\
\text { Terminal Rates (c) } \\
\text { Life Table Tests (d) } \\
\text { Cochran-Armitage Trend Test (d) } \\
\text { Fisher Exact Tests }\end{array}$ & $\begin{array}{l}0 / 49(0 \%) \\
0.0 \% \\
0 / 46(0 \%) \\
P=0.248 \\
P=0.381\end{array}$ & $\begin{array}{l}3 / 42(7 \%) \\
20.0 \% \\
3 / 15(20 \%) \\
P=0.008 \\
P=0.094\end{array}$ & $\begin{array}{l}1 / 49(2 \%) \\
3.3 \% \\
1 / 30(3 \%) \\
P=0.415 \\
P=0.500\end{array}$ \\
\hline $\begin{array}{l}\text { Forestomach: All Papilloma } \\
\text { Overall Rates (a) } \\
\text { Adjusted Rates (b) } \\
\text { Terminal Rates (c) } \\
\text { Lifo Table Tests (d) } \\
\text { Cochran-Armitage Trend Test (d) } \\
\text { Fisher Exact Tests }\end{array}$ & $\begin{array}{l}0 / 49(0 \%) \\
0.0 \% \\
0 / 46(0 \%) \\
P<0.001 \\
P<0.001\end{array}$ & $\begin{array}{l}4 / 42(10 \%) \\
26.7 \% \\
4 / 15(27 \%) \\
P=0.001 \\
P=0.042\end{array}$ & $\begin{array}{l}10 / 49(20 \%) \\
31.8 \% \\
9 / 30(30 \%) \\
P<0.001 \\
P<0.001\end{array}$ \\
\hline $\begin{array}{l}\text { Forestomach: Squamous Cell Papil } \\
\text { Overall Rates (a) } \\
\text { Adjusted Rates (b) } \\
\text { Terminal Rates (c) } \\
\text { Life Table Tests (d) } \\
\text { Cochran-Armitage Trend Test (d) } \\
\text { Fisher Exact Tests }\end{array}$ & $\begin{array}{l}\mathrm{ma} \\
0 / 49(0 \%) \\
0.0 \% \\
0 / 46(0 \%) \\
P=0.249 \\
P=0.393\end{array}$ & $\begin{array}{l}4 / 42(10 \%) \\
22.9 \% \\
3 / 15(20 \%) \\
P=0.003 \\
P=0.042\end{array}$ & $\begin{array}{l}1 / 49(2 \%) \\
3.4 \% \\
1 / 29(3 \%) \\
P=0.408 \\
P=0.500\end{array}$ \\
\hline $\begin{array}{l}\text { Forestomach: All Papilloma or Car } \\
\text { Overall Rates (a) } \\
\text { Adjusted Rates (b) } \\
\text { Terminal Rates (c) } \\
\text { Life Table Tests (d) } \\
\text { Cochran-Armitage Trend Test (d) } \\
\text { Fisher Exact Tests }\end{array}$ & $\begin{array}{l}0 / 49(0 \%) \\
0.0 \% \\
0 / 46(0 \%) \\
P<0.001 \\
P<0.001\end{array}$ & $\begin{array}{l}5 / 42(12 \%) \\
29.3 \% \\
415(27 \%) \\
P<0.001 \\
P=0.018\end{array}$ & $\begin{array}{l}10 / 49(20 \%) \\
31.8 \% \\
9 / 30(30 \%) \\
P<0.001 \\
P<0.001\end{array}$ \\
\hline $\begin{array}{l}\text { Mammary Gland: Acinar Cell Carc } \\
\text { Overall Rates (a) } \\
\text { Adjusted Rates (b) } \\
\text { Terminal Rates (c) } \\
\text { Life Table Tests (d) } \\
\text { Cochran-Armitage Trend Test (d) } \\
\text { Fisher Exact Tests }\end{array}$ & $\begin{array}{l}0 / 50(0 \%) \\
0.0 \% \\
0 / 4610 \%) \\
P=0.004 \\
P=0.007\end{array}$ & $\begin{array}{l}2 / 49(4 \%) \\
13.3 \% \\
2 / 15(13 \%) \\
P=0.048 \\
P=0.242\end{array}$ & $\begin{array}{l}6 / 49(12 \%) \\
16.7 \% \\
3 / 30(10 \%) \\
P=0.007 \\
P=0.012\end{array}$ \\
\hline $\begin{array}{l}\text { Mammary Gland: Adenosquamous } \\
\text { Overall Rates (a) } \\
\text { Adjusted Rates (b) } \\
\text { Terminal Rates (c) } \\
\text { Life Table Tests (d) } \\
\text { Cochran-Armitage Trend Test (d) } \\
\text { Fisher Exact Tests }\end{array}$ & $\begin{array}{l}0 / 50(0 \%) \\
0.0 \% \\
0 / 46(0 \%) \\
P=0.575 \\
P=0.615\end{array}$ & $\begin{array}{l}4 / 49(8 \%) \\
11.9 \% \\
0 / 15(0 \%) \\
P=0.030 \\
P=0.056\end{array}$ & $\begin{array}{l}0 / 49(0 \%) \\
0.0 \% \\
0 / 30(0 \%) \\
\text { (e) } \\
\text { (e) }\end{array}$ \\
\hline
\end{tabular}


TABLE C2. ANALYSIS OF PRIMARY TUMORS IN FEMALE MICE IN THE SIXTY-ONE-WEEK INHALATION STUDY OF 1,3-BUTADIENE (Continued)

\begin{tabular}{llll}
\hline & Control & 625 ppm & 1,250 ppm \\
\hline $\begin{array}{l}\text { Ovary: Granulosa Cell Tumor } \\
\text { Overall Rates (a) }\end{array}$ & & & $12 / 48(25 \%)$ \\
Adjusted Rates (b) & $0 / 49(0 \%)$ & $6 / 45(13 \%)$ & $36.6 \%$ \\
Terminal Rates (c) & $0.0 \%$ & $33.4 \%$ & $9 / 29(31 \%)$ \\
Life Table Tests (d) & $0 / 46(0 \%)$ & $4 / 15(27 \%)$ & $\mathrm{P}<0.001$ \\
Cochran-Armitage Trend Test (d) & $\mathrm{P}<0.001$ & $\mathrm{P}<0.001$ & $\mathrm{P}<0.001$ \\
Fisher Exact Tests & $\mathrm{P}<0.001$ & $\mathrm{P}=0.010$ & $13 / 48(27 \%)$ \\
Ovary: Granulosa Cell Tumor or Carcinoma & & & $39.8 \%$ \\
Overall Rates (a) & & $6 / 49(0 \%)$ & $10 / 29(34 \%)$ \\
Adjusted Rates (b) & $0.0 \%$ & $33.4 \%$ & $\mathrm{P}<0.001$ \\
Terminal Rates (c) & $0 / 46(0 \%)$ & $4 / 15(27 \%)$ & $\mathrm{P}<0.001$ \\
Life Table Tests (d) & $\mathrm{P}<0.001$ & $\mathrm{P}<0.001$ & $\mathrm{P}=0.010$ \\
Cochran-Armitage Trend Test (d) & $\mathrm{P}<0.001$ & & \\
Fisher Exact Tests & & & \\
\hline
\end{tabular}

(a) Number of tumor-bearing animals/number of animals examined at the site

(b) Kaplan-Meier estimated tumor incidence at the end of the study after adjusting for intercurrent mortality (c) Observed tumor incidence at terminal kill

(d) Beneath the control incidence are the $P$ values associated with the trend test. Beneath the dosed group incidence are the $P$ values corresponding to pairwise comparisons between that dosed group and the controls. The life table analysis regards tumors in animals dying prior to terminal kill as being (directly or indirectly) the cause of death. The Cochran-Armitage and Fisher's exact test compare directly the overall incidence rates. A negative trend or lower incidence in a dosed group is indicated by $(\mathrm{N})$.

(e) No $P$ value is presented because no tumors were observed in the 1,250-ppm and control groups. 


\section{APPENDIX D}

\section{CHEMICAL CHARACTERIZATION OF \\ 1,3-BUTADIENE}


1,3-Butadiene was analyzed by infrared spectroscopy and gas chromatography by the testing laboratory. More than 15 lots were used. The analysis of Lot No. B-915, the first lot used in the 60- to 61 -week studies, follows. Results for analysis of all lots for purity and dimer content are presented in Table D1.

\section{Infrared Spectroscopy}

A. Method: Approximately $6 \mathrm{ml}$ of gas was placed in an evacuated $10-\mathrm{cm}$ path gas cell with sodium chloride windows. A Beckman Acculab 6 spectrophotometer was used.

B. Results: The spectrum was consistent with the previous spectra and those from Midwest Research Institute (Figure 3).

\section{Gas Chromatography}

\section{A. Method:}

Sample size: $0.5 \mathrm{ml}$

Column: $2.35 \mathrm{~m} \times 2 \mathrm{~mm}$ ID, Porapak QS

Detector: Flame ionization

Detector temperature: $250^{\circ} \mathrm{C}$

Oven temperature: $100^{\circ} \mathrm{C}$ isothermal for $20 \mathrm{~min}$

Injection temperature: $200^{\circ} \mathrm{C}$

Flow rate: $20 \mathrm{ml} / \mathrm{min}$

B. Results: A main peak and three trace impurities were detected:

\begin{tabular}{|c|c|}
\hline Injection & $\begin{array}{c}\text { Purity (percent } \\
\text { (of total area) }\end{array}$ \\
\hline $\begin{array}{l}1 \\
2 \\
3 \\
\text { Mean }\end{array}$ & $\begin{array}{l}98.890 \\
99.118 \\
98.818 \\
98.94\end{array}$ \\
\hline
\end{tabular}

\section{Gas Chromatography, Dimer Analysis}

\section{A. Method:}

Sample size: $0.3 \mathrm{ml}$

Column: $1 \mathrm{~m} \times 2 \mathrm{~mm}$ ID, Porapak PS 80/100

Detector: Flame ionization

Detector temperature: $275^{\circ} \mathrm{C}$

Oven temperature: $150^{\circ} \mathrm{C}$ isothermal for $8 \mathrm{~min}$

Injection temperature: $200^{\circ} \mathrm{C}$

Flow rate: $30 \mathrm{ml} / \mathrm{min}$

B. Results: The largest impurity had a retention time of 0.65 minutes and a mean area of $1.05 \%$. One peak greater than $0.5 \%$ by area percent was noted but no dimer was detected. 


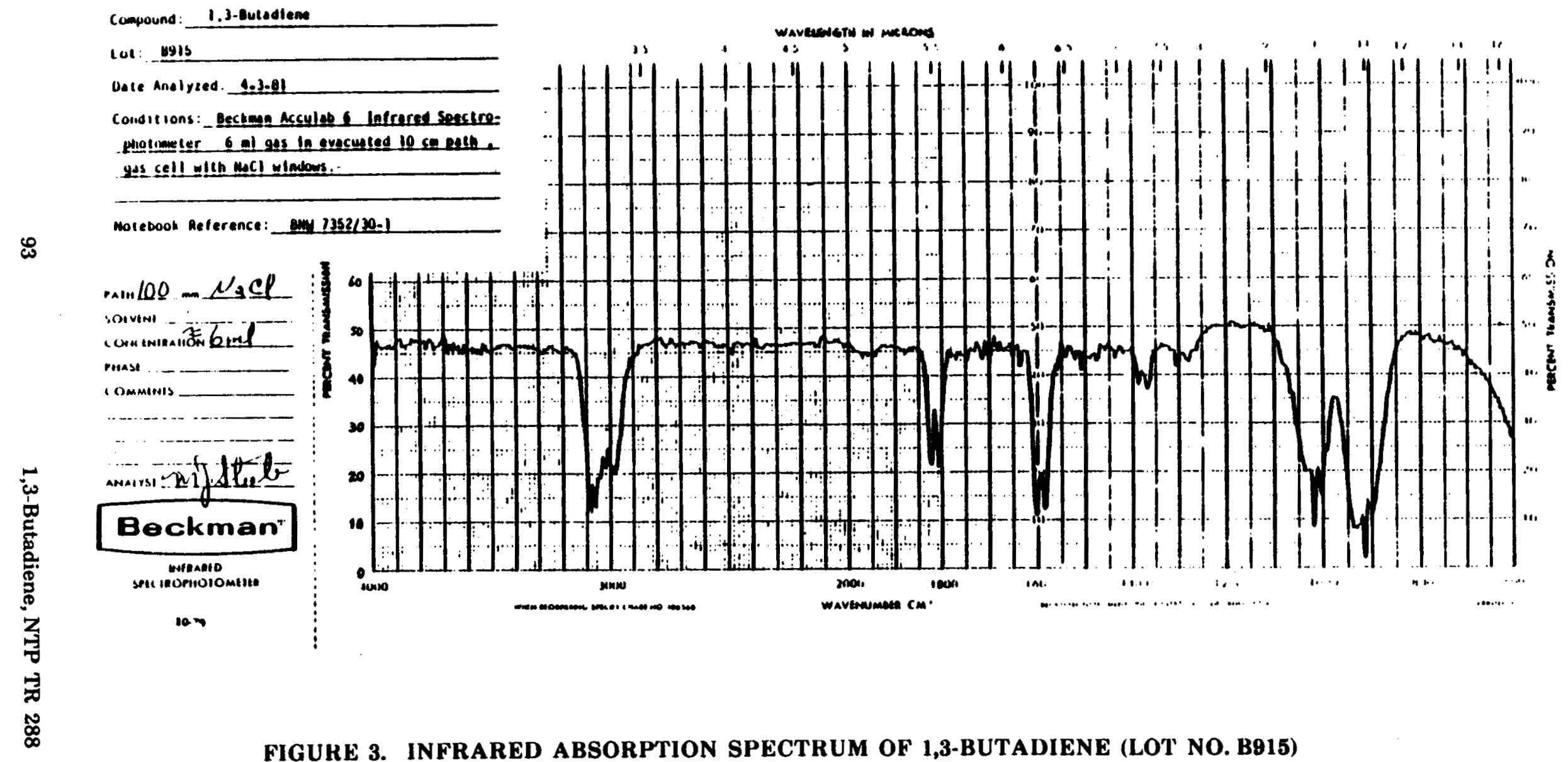




\section{Determination of Rapidly Eluting Impurity}

A. Method: Gas chromatography

Sample size: $0.05 \mathrm{ml}$ vapor

Column: $1 \%$ SP1000 on Carbopack B $60 / 80,4$ feet $\times 2 \mathrm{~mm} \mathrm{ID,} \mathrm{glass}$

Carrier: Helium

Flow rate: $27 \mathrm{ml} / \mathrm{min}$

Detector: Flame ionization

Detector temperature: $250^{\circ} \mathrm{C}$

Oven temperature: $70^{\circ} \mathrm{C}$, isothermal

Injection temperature: $200^{\circ} \mathrm{C}$

B. Results: This chromatographic analysis verified the presence of the rapidly eluting impurity in the butadiene sample. The average concentration was $0.67 \%$ by area. Analysis of propane and methane standards indicated that the impurity was probably methane. The impurity shows a retention time of 0.50-0.43 minutes. Methane exhibits a 0.44 -minute retention time.

V. Conclusions: The infrared spectrum is consistent with previous data and with the Midwest Research Institute spectra. The purity is $98.94 \%$ as determined by gas chromatography. A rapidly migrating impurity of greater than $0.5 \%$ by area, but no dimer, was detected. Analysis of standards indicated that the rapidly eluting impurity was probably methane.

TABLE D1. SUMMARY OF PURITY OF 1,3-BUTADIENE IN THE SIXTY-ONE-WEEK INHALATION STUDIES

\begin{tabular}{|c|c|c|c|c|c|c|c|}
\hline $\begin{array}{l}\text { Lot } \\
\text { Number }\end{array}$ & $\begin{array}{c}\text { Date } \\
\text { Received }\end{array}$ & $\begin{array}{c}\text { Dates } \\
\text { Analyzed }\end{array}$ & $\begin{array}{l}\text { Date } \\
\text { on } \\
\text { Test }\end{array}$ & $\begin{array}{c}\text { Purity by } \\
\text { Area } \\
\text { Percent }\end{array}$ & $\begin{array}{l}\text { Dimer } \\
\text { Content } \\
(\text { ppm }(\mathbf{a})\end{array}$ & $\begin{array}{c}\text { Dimer } \\
\text { Content } \\
\text { (mole percent) }(b)\end{array}$ & $\begin{array}{l}\text { Cylinder } \\
\text { Capacity } \\
\text { (gallons) }\end{array}$ \\
\hline $\begin{array}{l}\text { B-915 } \\
\text { B-899B } \\
\text { B-962 } \\
\text { B-996 } \\
\text { F-037 } \\
\text { F-047 } \\
F-089 A(c) \\
\text { F-105 } \\
F-089 B(d) \\
\text { F.089C(f) } \\
\text { F-120 } \\
\text { F-159 } \\
\text { F.193 } \\
\text { F-207 } \\
\text { F-238 } \\
\text { F.207 } \\
\text { F-207(g) }\end{array}$ & $\begin{array}{l}03 / 31 / 81 \\
05 / 06 / 81 \\
05 / 29 / 81 \\
06 / 30 / 81 \\
08 / 20 / 81 \\
09 / 09 / 81 \\
10 / 29 / 81 \\
12 / 10 / 81 \\
10 / 29 / 81 \\
10 / 29 / 81 \\
01 / 14 / 82 \\
02 / 09 / 82 \\
03 / 31 / 82 \\
04 / 21 / 82 \\
05 / 28 / 82 \\
04 / 21 / 82 \\
04 / 21 / 82\end{array}$ & $\begin{array}{l}04 / 03 / 81 \\
05 / 08 / 81 \\
06 / 03 / 81 \\
07 / 09 / 81 \\
08 / 21 / 81 \\
09 / 10 / 81 \\
10 / 30 / 81 \\
12 / 11 / 81 \\
12 / 11 / 81 \\
12 / 14 / 81 \\
01 / 15 / 82 \\
02 / 12 / 82 \\
03 / 31 / 82 \\
04 / 22 / 82 \\
06 / 07 / 82 \\
06 / 08 / 82 \\
06 / 29 / 82 \\
06 / 30 / 82\end{array}$ & $\begin{array}{l}04 / 15 / 81 \\
05 / 12 / 81 \\
06 / 15 / 81 \\
07 / 13 / 81 \\
08 / 25 / 81 \\
09 / 14 / 81 \\
11 / 10 / 81 \\
\text { Rejected } \\
12 / 14 / 81 \\
12 / 15 / 81 \\
01 / 18 / 82 \\
02 / 22 / 82 \\
04 / 02 / 82 \\
04 / 23 / 82 \\
\text { Rejected } \\
04 / 23 / 82 \\
04 / 23 / 82\end{array}$ & $\begin{array}{c}98.94 \\
99.72 \\
99.34 \\
99.73 \\
99.87 \\
100.0 \\
99.85 \\
99.98 \\
(e) \\
100.0 \\
99.99 \\
99.99 \\
99.67 \\
99.86 \\
99.80 \\
(e) \\
99.85\end{array}$ & $\begin{array}{r}0 \\
0 \\
102 \\
18 \\
104 \\
74 \\
43 \\
328 \\
140 \\
44 \\
37 \\
51 \\
38 \\
27 \\
119 \\
111 \\
116\end{array}$ & $\begin{array}{l}0.05 \\
0.10 \\
0.20 \\
0.45 \\
0.40 \\
0.35 \\
0.10 \\
0.07\end{array}$ & $\begin{array}{r}16 \\
28 \\
28 \\
28 \\
28 \\
28 \\
5 \\
28 \\
5 \\
5 \\
28 \\
28 \\
28 \\
28 \\
28 \\
28 \\
28\end{array}$ \\
\hline
\end{tabular}

(a) Dimer content in headspace, determined at testing laboratory

(b) Dimer content in the liquid, determined by the manufacturer. Dimer content in liquid and headspace are not directly comparable.

(c) Tank one of three of lot F.089

(d) Tank two of three of lot F-089

(e) Only dimer was determined.

(f) Tank three of three of lot F-089; assayed for dimer only on $01 / 07 / 82(316 \mathrm{ppm})$ and $01 / 18 / 82(1,540 \mathrm{ppm})$

(g) Purity assay performed after end of 61 -week studies 


\section{APPENDIX E}

\section{GENERATION AND MONITORING OF CHAMBER CONCENTRATIONS}


I. Atmospheric Generation System: The generation system used to deliver butadiene gas to each exposure chamber is depicted in Figure 4. Butadiene was supplied in 5- or 28-gallon gas cylinders located in the animal exposure room. The natural bottle pressure (about $147 \mathrm{psi}$ at room temperature) was reduced to an operating pressure of $54 \mathrm{psi}$ by a Union Carbide single-stage regulator. A nitrogen purge tee and check valve preceded this regulator to allow clearing of the entire gas distribution system for system maintenance or exchange of gas bottles.

The butadiene was piped to a polyethylene vapor hood containing safety devices, comprised of two emergency shutoff valves and a pressure gauge. These safety devices were incorporated in the hood (vented to the room exhaust) to minimize the hazard to animals and personnel in the event of a leak. The gas was then piped to a second hood containing two double-pattern metering valves. Since the upstream pressure to these valves was well regulated, these valves provided stable control of the gas flow rate and ultimately the concentration in the chambers. To provide the proper chamber concentration, the valves were set and periodically checked, by matching the calculated with the actual flow measured by a bubble meter. From the double-pattern metering valves, the gas was piped to each exposure chamber. A shutoff valve at the entrance to the chamber permitted easy, rapid termination of gas flow. All materials in the gas distribution system were stainless steel, Teflon, Viton ${ }^{\oplus}$, or brass.

To help prevent the possibility of concentration excursions in the exposure chambers, several safety systems were incorporated. One of each of the two series valves, incorporated in the double-pattern metering valves, was used as a flow-limiting valve, the other as a flow-control valve. The limiting valve was set to limit the maximum flow to $20 \%$ greater than the nominal flow calculated to provide the target chamber concentration. Two explosion-proof solenoid shutoff valves connected in series were operated by the general alarm systems. These valves would automatically shut off the flow of gas to the chambers whenever an alarm situation occurred. 


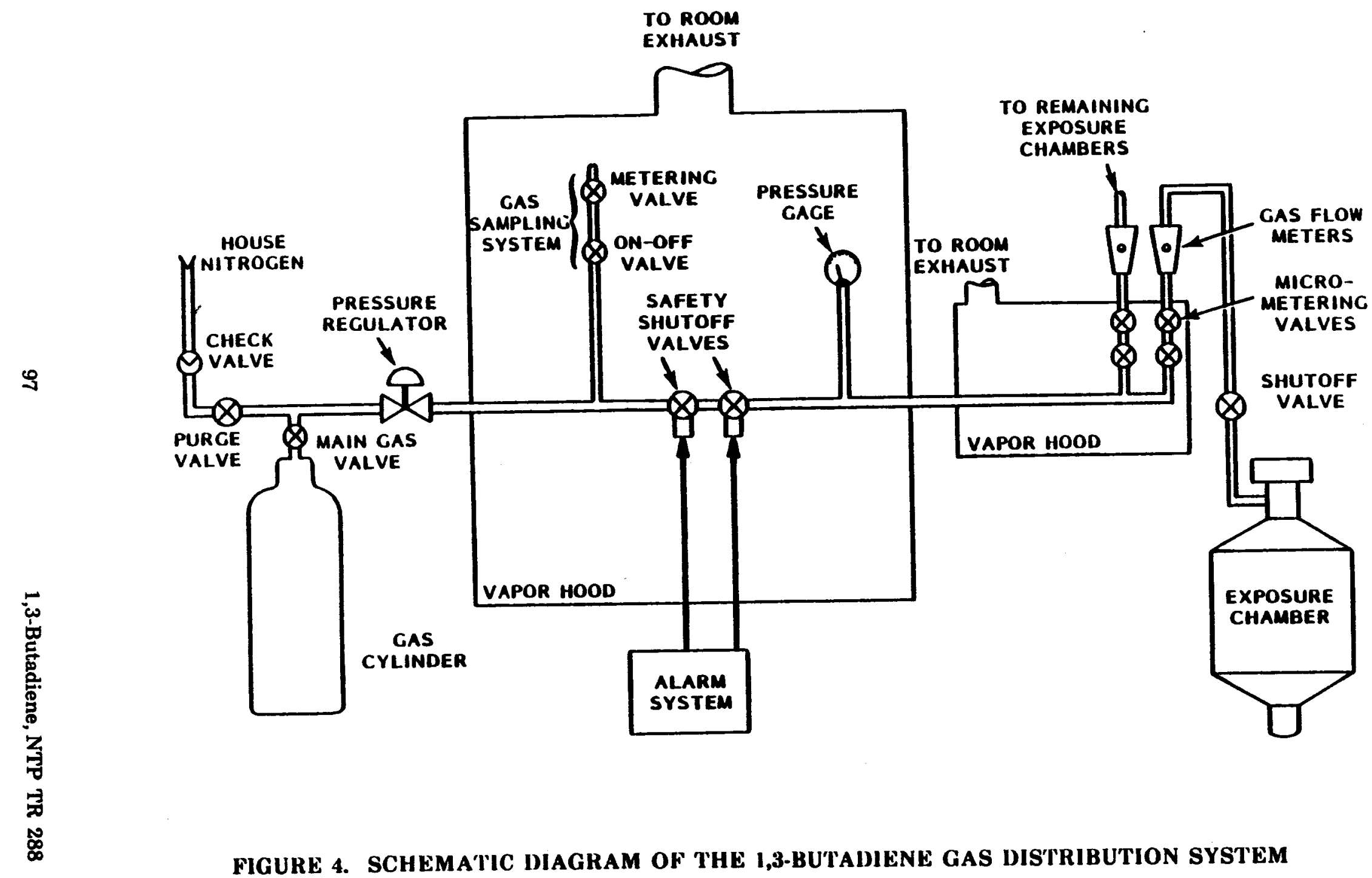


II. Vapor Concentration Uniformity in the Chamber: The uniformity of vapor concentrations in the exposure chambers was measured periodically throughout the study with a portable photoionization detector at 12 positions (two positions, one in front $[\mathrm{F}]$ and one in back [B], for each of the six animal cage units per chamber). The sample point was just above and about $10 \mathrm{~cm}$ in from the front or back center of each cage unit (Figure 5). The data, normalized at all 12 sample positions for each chamber, are presented in Table $\mathrm{E} 1$.

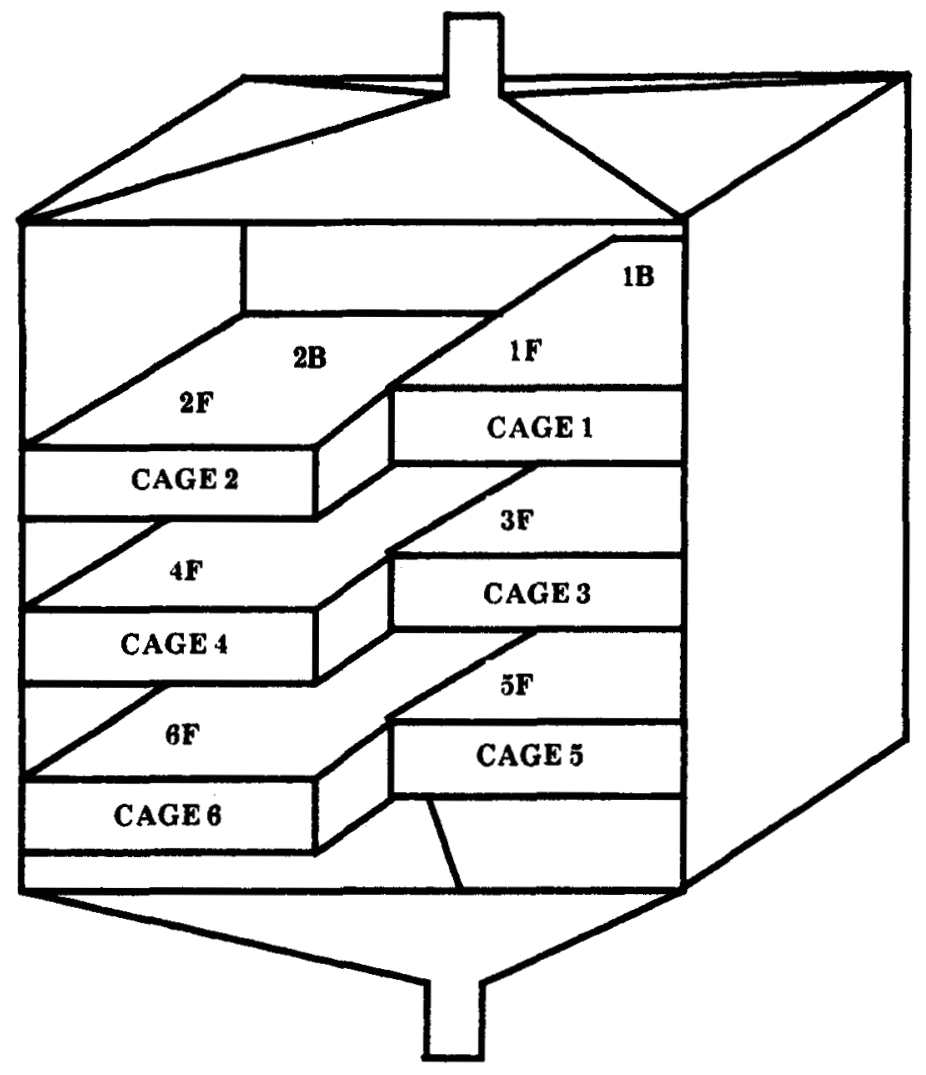

FIGURE 5. SCHEMATIC FRONT VIEW OF CHAMBER SHOWING APPROXIMATE SAMPLE SITES 
TABLE E1. 1,3-BUTADIENE VAPOR CONCENTRATION UNIFORMITY TEST

\begin{tabular}{|c|c|c|c|c|c|c|}
\hline $\begin{array}{l}\text { Sample Date } \\
\text { Sample Location }\end{array}$ & $\begin{array}{c}04 / 01 / 81 \\
\text { Chamber } A(a) \\
\text { (percent) }\end{array}$ & $\begin{array}{c}04 / 01 / 81 \\
\text { Chamber B (b) } \\
\text { (percent) }\end{array}$ & $\begin{array}{c}03 / 09 / 82 \\
\text { Chamber A } \\
\text { (percent) }\end{array}$ & $\begin{array}{c}\text { 03/09/82 } \\
\text { Chamber B } \\
\text { (percent) }\end{array}$ & $\begin{array}{c}05 / 20 / 82 \\
\text { Chamber A } \\
\text { (percent) }\end{array}$ & $\begin{array}{c}05 / 20 / 82 \\
\text { Chamber B } \\
\text { (percent) }\end{array}$ \\
\hline $1 F$ & 101 & 103 & 100 & 99 & 100 & 102 \\
\hline $1 \mathrm{~B}$ & 100 & 100 & 101 & 100 & 102 & 100 \\
\hline $2 F$ & 100 & 98 & 100 & 101 & 102 & 101 \\
\hline $2 B$ & 101 & 100 & 100 & 101 & 102 & 103 \\
\hline $3 F$ & 100 & 100 & 99 & 100 & 98 & 99 \\
\hline $3 B$ & 99 & 98 & 100 & 98 & 99 & 100 \\
\hline $4 F$ & 99 & 101 & 99 & 101 & 102 & 100 \\
\hline $4 B$ & 100 & 98 & 100 & 98 & 99 & 99 \\
\hline $5 F$ & 100 & 101 & 99 & 102 & 98 & 99 \\
\hline $5 \bar{B}$ & 100 & 98 & 100 & 98 & 99 & 99 \\
\hline $6 F$ & 101 & 103 & 101 & 103 & 102 & 97 \\
\hline $6 \mathrm{~B}$ & 100 & 100 & 100 & 100 & 99 & 103 \\
\hline Mean $\pm S D$ & $100 \pm 1$ & $100 \pm 1$ & $100 \pm 1$ & $100 \pm 2$ & $100 \pm 2$ & $100 \pm 2$ \\
\hline
\end{tabular}

(a) Chamber A housed animals exposed at 625 ppm 1,3-butadiene.

(b) Chamber $B$ housed animals exposed at 1,250 ppm 1,3-butadiene.

III. Chamber Concentration Monitoring System: Butadiene concentrations in the exposure chambers, control chamber, and exposure room were automatically monitored 7-12 times during each exposure day with a photoionization detector (PID) for the first 150 days or a Hewlett Packard 5840A gas chromatograph (GC) equipped with a flame ionization detector from day 151 to termination. The calibration of the PID was checked every 10 days with a "bag" standard prepared by the testing facility and daily with a propylene on-line standard. The GC was calibrated at least monthly with the "bag" standard.

During exposures, samples from each sampling location were continuously drawn by vacuum through stainless steel sample lines to the input of an automatic, multiplexed, 8-port sample valve. The constant flow assured fresh samples at the 8-port valve.

Weekly concentrations are graphically represented in Figures 6 and 7. 


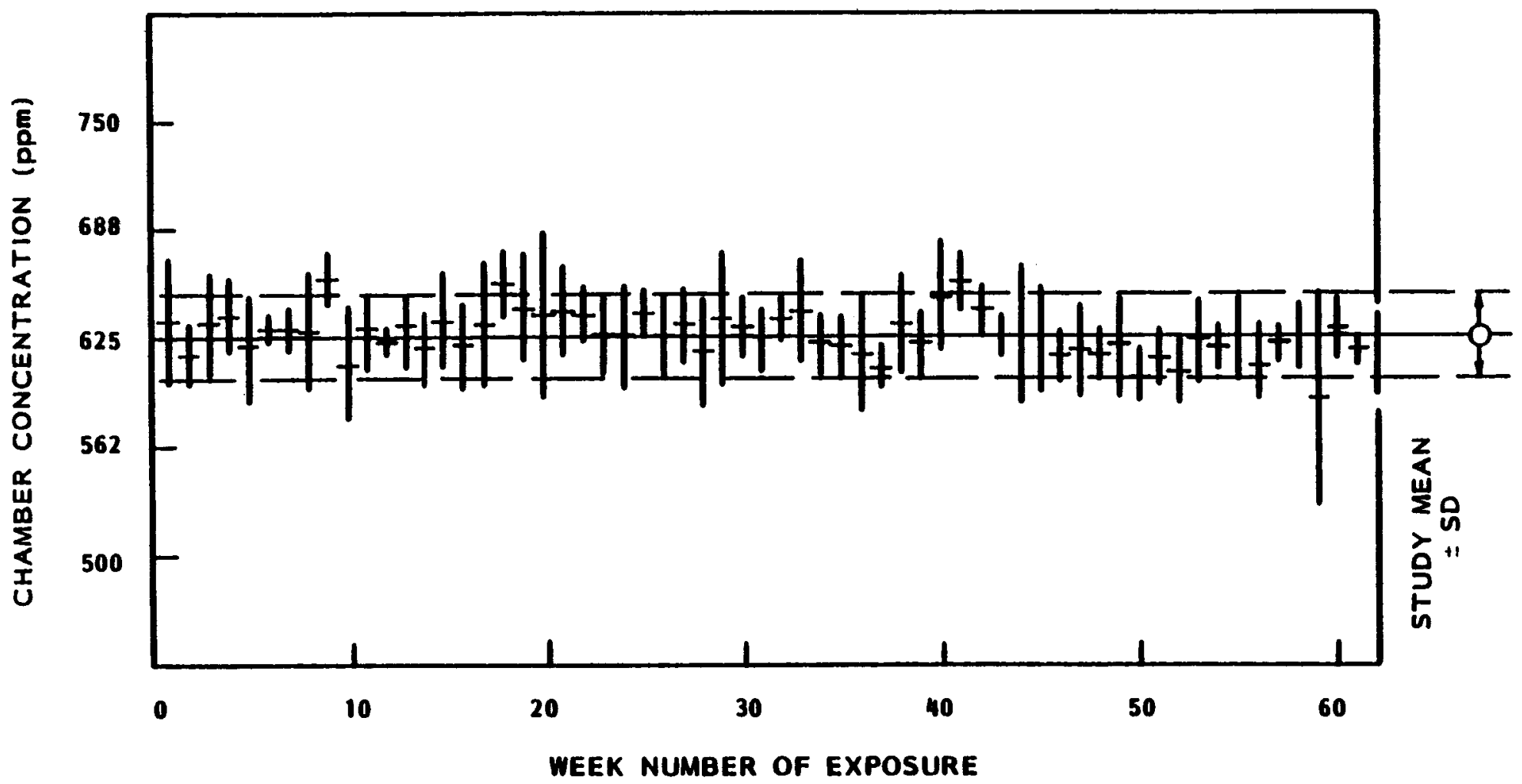

FIGURE 6. WEEKLY MEAN CONCENTRATION AND STANDARD DEVIATION (bars) IN 625-PPM MOUSE EXPOSURE CHAMBER FOR ENTIRE SIXTY-ONE-WEEK STUDIES 


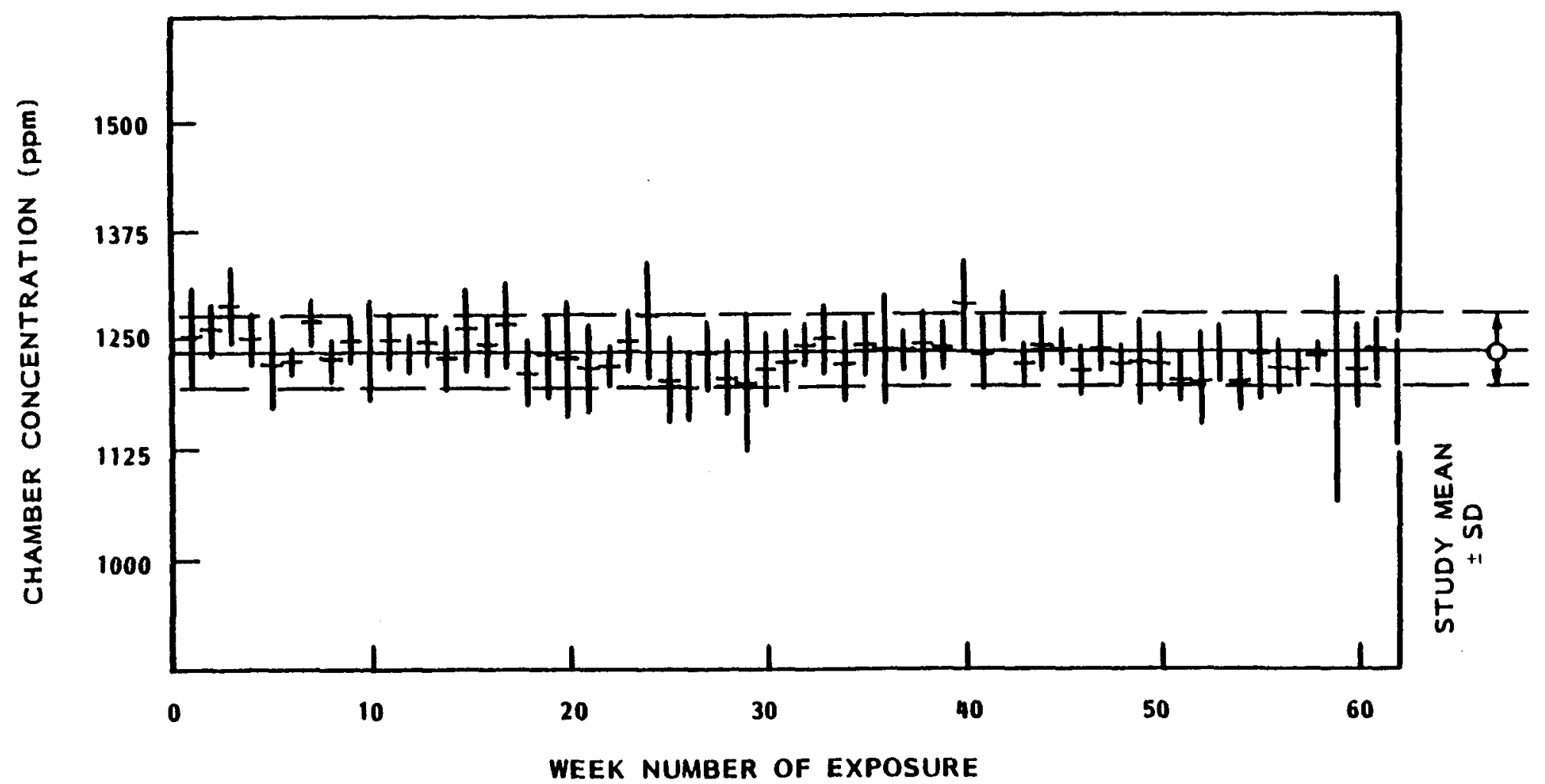

FIGURE 7. WEEKLY MEAN CONCENTRATION AND STANDARD DEVIATION (bars) IN 1,250-PPM MOUSE EXPOSURE CHAMBER FOR ENTIRE SIXTY-ONE-WEEK STUDIES 


\section{APPENDIX F}

\section{RESULTS OF SEROLOGIC ANALYSES}




\section{A. METHODS}

Data from animals surviving to the end of the studies (60 or 61 weeks) were collected from $5 / 50$ randomly selected control animals of each sex. The blood from each animal was collected and clotted, and the serum was separated. The serum was cooled on ice and shipped to Microbiological Associates' Comprehensive Animal Diagnostic Service for determination of the viral antibody titers. The following tests were performed:

\section{Hemagglutination} Inhibition

PVM (pneumonia virus of mice)

Reo 3 (reovirus type 3)

GDVII (Theiler's

encephalomyelitis virus)

Poly (polyoma virus)

MVM (minute virus of mice)

Ectro (infectious ectromelia)

Sendai

\section{Complement \\ Fixation}

M.Ad. (mouse adenovirus)

LCM (lymphocytic choriomeningitis virus)

\section{ELISA}

MHV (mouse hepatitis virus)

\section{B. RESUltS}

TABLE F1. MURINE VIRUS ANTIBODY DETERMINATIONS IN MICE IN THE SIXTY.ONE.WEEK INHALATION STUDIES OF 1,3-BUTADIENE

\begin{tabular}{lcc}
\hline Interval (weeks) & $\begin{array}{c}\text { No. of } \\
\text { Animals }\end{array}$ & $\begin{array}{c}\text { Positive Serologic } \\
\text { Reaction for }\end{array}$ \\
\hline
\end{tabular}

MALE

FEMALE 


\section{APPENDIX G}

\section{INGREDIENTS, NUTRIENT COMPOSITION, AND}

\section{MEASURED CONTAMINANT LEVELS OF NIH O7 DIET}

Pelleted Diet: February 1981 to May 1982

(Manufactured by Zeigler Bros., Inc.)

(Gardners, PA) 
TABLE G1. INGREDIENTS OF NIH O7 RAT AND MOUSE DIET (a)

\begin{tabular}{lc}
\hline Ingredients (b) & Percent by Weight \\
\hline Ground \#2 yellow shelled corn & 24.50 \\
Ground hard winter wheat & 23.00 \\
Soybean meal (49\% protein) & 12.00 \\
Fish meal (60\% protein) & 10.00 \\
Wheat middlings & 10.00 \\
Dried skim milk & 5.00 \\
Alfalfa meal (dehydrated, 17\% protein) & 4.00 \\
Corn gluten meal (60\% protein) & 3.00 \\
Soy oil & 2.50 \\
Brewer's dried yeast & 2.00 \\
Dry molasses & 1.50 \\
Dicalcium phosphate & 1.25 \\
Ground limestone & 0.50 \\
Salt & 0.50 \\
Pre-mixes (vitamins and minerals)(c) & 0.25 \\
\hline
\end{tabular}

(a) Prepared according to NIH, 1978; NCI, 1976

(b) Ingredients should be ground to pass through a U.S. Standard Screen $\# 16$ before mixing.

(c) Details given in Table G2

TABLE G8. VITAMINS AND MINERALS IN THE NIH O7 DIET (a)

Amount Source

Vitamins

A

\section{$\mathrm{D}_{3}$}

$\mathrm{K}_{3}$

d.A-tocopheryl acetate

Choline

Folic acid

Niacin

d-Pantothenic acid

Riboflavin

Thiamine

B12

Pyridoxine

Biotin

$5,500,000 \mathrm{IU}$
$4,600,000 \mathrm{IU}$
$2.8 \mathrm{~g}$
$20,000 \mathrm{IU}$
$560.0 \mathrm{~g}$
$2.2 \mathrm{~g}$
$30.0 \mathrm{~g}$
$18.0 \mathrm{~g}$
$3.4 \mathrm{~g}$
$10.0 \mathrm{~g}$
$4.000 \mu \mathrm{g}$
$1.7 \mathrm{~g}$
$140.0 \mathrm{mg}$

Minerals

\begin{tabular}{lrl} 
Cobalt & $0.4 \mathrm{~g}$ & Cobaltcarbonate \\
Copper & $4.0 \mathrm{~g}$ & Copper sulfate \\
Iron & $120.0 \mathrm{~g}$ & Iron sulfate \\
Manganese & $60.0 \mathrm{~g}$ & Manganous oxide \\
Zine & $16.0 \mathrm{~g}$ & Zinc oxide \\
lodine & $1.4 \mathrm{~g}$ & Calcium iodate \\
\hline
\end{tabular}

\author{
Stabilized vitamin A \\ palmitate or acetate \\ Dactivated animal sterol \\ Menadione activity \\ Choline chloride \\ d.Calcium pantothenate \\ Thiamine mononitrate \\ Pyridoxine hydrochloride \\ d-biotin
}

(a) Per ton (2,000 lb) of finished product 
TABLE G3. NUTRIENT COMPOSITION OF NIH O7 DIET: PELLETS

\begin{tabular}{|c|c|c|c|}
\hline Nutrient (percent by weight) & Mean & Range & Number of Samples \\
\hline $\begin{array}{l}\text { Crude protein } \\
\text { Crude fat } \\
\text { Crude fiber } \\
\text { Ash }\end{array}$ & $\begin{array}{r}24.18 \pm 0.83 \\
4.88 \pm 0.37 \\
3.35 \pm 0.23 \\
6.41 \pm 0.45\end{array}$ & $\begin{array}{l}22.7-25.1 \\
4.2-5.5 \\
2.9 \cdot 3.6 \\
5.8 \cdot 7.43\end{array}$ & $\begin{array}{l}14 \\
14 \\
14 \\
14\end{array}$ \\
\hline \multicolumn{4}{|l|}{ Vitamins } \\
\hline $\begin{array}{l}\text { Vitamin A (IU/kg) } \\
\text { Vitamin D (IU/kg) } \\
\text { A-tocopherol (ppm) } \\
\text { Thiamine (ppm) } \\
\text { Riboflavin (ppm) } \\
\text { Niacin (ppm) } \\
\text { Pantothenic acid (ppm) } \\
\text { Pyridoxine (ppm) } \\
\text { Folic acid (ppm) } \\
\text { Biotin (ppm) } \\
\text { Vitamin B } 12 \text { (ppm) } \\
\text { Choline (ppm) }\end{array}$ & $\begin{array}{l}11,088 \pm 1,872 \\
6,300 \\
37.6 \\
17.3 \pm 1.44 \\
6.9 \\
75 \\
30.2 \\
7.2 \\
2.1 \\
0.13 \\
12.8 \\
3,315\end{array}$ & $\begin{array}{l}880 \cdot 1,500 \\
31.1 \cdot 44.0 \\
15.0 \cdot 19.0 \\
6.1 \cdot 7.4 \\
65 \cdot 85 \\
29.8 \cdot 30.5 \\
5.6 \cdot 8.8 \\
1.8 \cdot 2.4 \\
0.21 \cdot 0.27 \\
10.6 \cdot 15.0 \\
3,200 \cdot 3,430\end{array}$ & $\begin{array}{r}14 \\
\text { (a) } 1 \\
\text { (a) } 2 \\
13 \\
\text { (a) } 2 \\
2 \\
2 \\
\text { (a) } 2 \\
\text { (a) } 2 \\
\text { (a) } 2 \\
\text { (a) } 2 \\
\text { (a) } 2 \\
\text { (a) } 2\end{array}$ \\
\hline \multicolumn{4}{|l|}{ Minerals } \\
\hline $\begin{array}{l}\text { Calcium } \\
\text { Phosphorous } \\
\text { Potassium } \\
\text { Chloride } \\
\text { Sodium } \\
\text { Magnesium } \\
\text { Sulfur } \\
\text { Iron (ppm) } \\
\text { Manganese (ppm) } \\
\text { Zinc (ppm) } \\
\text { Copper (ppm) } \\
\text { lodine (ppm) } \\
\text { Chromium (ppm) } \\
\text { Cobalt (ppm) }\end{array}$ & $\begin{array}{l}1.24 \pm 0.17 \\
0.99 \pm 0.06 \\
0.809 \\
0.557 \\
0.304 \\
0.172 \\
0.278 \\
418 \\
90.8 \\
55.1 \\
12.68 \\
2.58 \\
1.86 \\
0.57\end{array}$ & $\begin{array}{l}1.08 \cdot 1.69 \\
0.88 \cdot 1.10 \\
0.772 \cdot 0.846 \\
0.479 \cdot 0.635 \\
0.258 \cdot 0.349 \\
0.166 \cdot 0.177 \\
0.270 \cdot 0.285 \\
409 \cdot 426 \\
86.0 \cdot 95.5 \\
54.2 \cdot 56.0 \\
9.65 \cdot 15.70 \\
1.52 \cdot 3.64 \\
1.79 \cdot 1.93 \\
0.49 \cdot 0.65\end{array}$ & $\begin{array}{l}14 \\
14 \\
\text { (a) } 2 \\
\text { (a) } 2 \\
\text { (a) } 2 \\
\text { (a) } 2 \\
\text { (a) } 2 \\
\text { (a) } 2 \\
\text { (a) } 2 \\
\text { (a) } 2 \\
\text { (a) } 2 \\
\text { (a) } 2 \\
\text { (a) } 2 \\
\text { (a) } 2\end{array}$ \\
\hline \multicolumn{4}{|l|}{ Essential Amino Acids } \\
\hline $\begin{array}{l}\text { Arginine } \\
\text { Cystine } \\
\text { Glycine } \\
\text { Histadine } \\
\text { Isoleucine } \\
\text { Leucine } \\
\text { Lysine } \\
\text { Methionine } \\
\text { Phenylalanine } \\
\text { Threonine } \\
\text { Tryptophan } \\
\text { Tyrosine } \\
\text { Valine }\end{array}$ & $\begin{array}{l}1.260 \\
0.395 \\
1.175 \\
0.553 \\
0.908 \\
1.905 \\
1.250 \\
0.310 \\
0.967 \\
0.834 \\
0.175 \\
0.587 \\
1.085\end{array}$ & $\begin{array}{l}1.21-1.31 \\
0.39-0.40 \\
1.15-1.20 \\
0.530 \cdot 0.576 \\
0.881-0.934 \\
1.85 \cdot 1.96 \\
1.20 \cdot 1.30 \\
0.306 \cdot 0.314 \\
0.960 \cdot 0.974 \\
0.827 \cdot 0.840 \\
0.171 \cdot 0.178 \\
0.566 \cdot 0.607 \\
1.05 \cdot 1.12\end{array}$ & $\begin{array}{l}\text { (a) } 2 \\
\text { (a) } 2 \\
\text { (a) } 2 \\
\text { (a) } 2 \\
\text { (a) } 2 \\
(a) 2 \\
(a) 2 \\
(a) 2 \\
(a) 2 \\
(a) 2 \\
\text { (a) } 2 \\
\text { (a) } 2 \\
\text { (a) } 2\end{array}$ \\
\hline \multicolumn{4}{|l|}{ Essential Fatty Acids } \\
\hline $\begin{array}{l}\text { Linoleic } \\
\text { Linolenic } \\
\text { Arachidonic }\end{array}$ & $\begin{array}{l}2.37 \\
0.308 \\
0.008\end{array}$ & & $\begin{array}{l}\text { (a) } 1 \\
\text { (a) } 1 \\
\text { (a) } 1\end{array}$ \\
\hline
\end{tabular}

(a) Analyses were done on batches of diet manufactured in January and/or April 1983. 
TABle G4. CONTAMinant leVels of NiH 07 DIET: PEllets

\begin{tabular}{|c|c|c|c|}
\hline Cuntaminant & $\underset{\text { Deviation }}{\text { Mean } \pm \text { Standard }}$ & Range & Number of Samples \\
\hline $\begin{array}{l}\text { Arsenic (ppm) } \\
\text { Cadmium (ppm) } \\
\text { Lead (ppm) } \\
\text { Mercury (ppm) } \\
\text { Selenium (ppm) } \\
\text { Aflatoxins (ppb) } \\
\text { Nitrate nitrogen (c) (ppm) } \\
\text { Nitrite nitrogen (c) (ppm) } \\
\text { BHA (d) (ppm) } \\
\text { BHT (d) (ppm) } \\
\text { Aerobic plate count (CFU/g) } \\
\text { Coliform (MPN/g) (f) } \\
\text { E. coli (MPN/g) } \\
\text { Total nitrosamines (ppb) } \\
\text { N-Nitrosodimethylamine (ppb) } \\
\text { N-Nitrosopyrrolidine (ppb) }\end{array}$ & $\begin{array}{c}0.45 \pm 0.19 \\
\text { (a) }<0.1 \\
0.92 \pm 0.62 \\
\text { (a)<0.05 } \\
0.30 \pm 0.07 \\
\text { (a) (b)<10 } \\
9.11 \pm 2.37 \\
2.27 \pm 1.81 \\
6.40 \pm 3.65 \\
3.04 \pm 1.56 \\
43,607 \pm 31,877 \\
17 \pm 26 \\
\text { (g) } 23 \\
\text { (h) } 2.61 \pm 1.02 \\
\text { (i) } 33.36 \pm 81.13 \\
\text { (j) } 1.35 \pm 0.386 \\
\text { (k) } 31.87 \pm 80.74 \\
1.26 \pm 0.92\end{array}$ & $\begin{array}{c}<0.29 \cdot 1.06 \\
0.50-1.02 \\
0.14 \cdot 0.40 \\
4.7-13.0 \\
0.4 \cdot 6.9 \\
\text { (e) }<0.4 \cdot 13.0 \\
0.9 \cdot 5.9 \\
4.900 \cdot 88,000 \\
<3 \cdot 93 \\
0.8-5.0 \\
0.8 \cdot 273.2 \\
0.8 \cdot 2.0 \\
0.8 \cdot 272 \\
0.0-3.5\end{array}$ & $\begin{array}{l}14 \\
14 \\
14 \\
14 \\
14 \\
14 \\
14 \\
14 \\
14 \\
14 \\
14 \\
14 \\
14 \\
12 \\
14 \\
12 \\
14 \\
14\end{array}$ \\
\hline \multicolumn{4}{|l|}{ Pesticides (ppm) } \\
\hline $\begin{array}{l}\text { Alpha BHC (1) } \\
\text { Beta BHC } \\
\text { Gamma BHC-Lindane } \\
\text { Delta BHC } \\
\text { Heptachlor } \\
\text { Aldrin } \\
\text { Heptachlor epoxide } \\
\text { DDE } \\
\text { DDD } \\
\text { DDT } \\
\text { HCB } \\
\text { Mirex } \\
\text { Methoxychlor } \\
\text { Dieidrin } \\
\text { Endrin } \\
\text { Telodrin } \\
\text { Chlordane } \\
\text { Toxaphene } \\
\text { Estiniated PCB's } \\
\text { Ronnel } \\
\text { Ethion } \\
\text { Trithion } \\
\text { Diazinon } \\
\text { Methyl parathion } \\
\text { Ethyl parathion } \\
\text { Malathion } \\
\text { Endosulfan I } \\
\text { Endosulfan II } \\
\text { Endosulfan sulfate }\end{array}$ & $\begin{array}{l}\text { (a) }<0.01 \\
\text { (a) }<0.02 \\
\text { (a) }<0.01 \\
\text { (a) }<0.01 \\
\text { (a) }<0.01 \\
\text { (a) }<0.01 \\
\text { (a) }<0.01 \\
\text { (a) }<0.01 \\
\text { (a) }<0.01 \\
\text { (a) }<0.01 \\
\text { (a) }<0.01 \\
\text { (a) }<0.01 \\
\text { (a) }<0.05 \\
\text { (a) }<0.01 \\
\text { (a) }<0.01 \\
\text { (a) }<0.01 \\
\text { (a) }<0.05 \\
\text { (a) }<0.1 \\
\text { (a) }<0.2 \\
\text { (a) }<0.01 \\
\text { (a) }<0.02 \\
\text { (a) }<0.05 \\
\text { (a) }<0.01 \\
\text { (a) }<0.02 \\
\text { (a) }<0.02 \\
0.09 \pm 0.06 \\
\text { (a) }<0.01 \\
\text { (a) }<0.01 \\
\text { (a) }<0.03\end{array}$ & $\begin{array}{l}(\mathrm{m}) 0.2(4 / 27 / 81) \\
(0)<0.05-0.27\end{array}$ & $\begin{array}{l}14 \\
14 \\
14 \\
14 \\
14 \\
14 \\
14 \\
14 \\
14 \\
14 \\
14 \\
14 \\
14 \\
14 \\
14 \\
14 \\
14 \\
14 \\
14 \\
14 \\
14 \\
14 \\
14 \\
14 \\
14 \\
14 \\
14 \\
14 \\
14\end{array}$ \\
\hline
\end{tabular}

(a) All values were less than the detection limit given.

(b) Detection limit reduced from $10 \mathrm{ppb}$ to $5 \mathrm{ppb}$ after $7 / 81$

(c) Source of contamination: alfalfa. grains, and fish meal

(d) Source of contamination: soy oil and fish meal

(e) One batch contained less than $0.4 \mathrm{ppm}$.

(f) $\mathrm{MPN}=$ most probable number

(g) All values were less than $3 \mathrm{MPN} / \mathrm{g}$

(h) All values were corrected for percent recovery; mean, standard deviation, and range exclude 2 very high values of 162.5 and $273.2 \mathrm{ppb}$ in batches produced on $2 / 23 / 81$ and $4 / 27 / 81$.

(i) All values were corrected for percent recovery; mean, standard deviation, and range include the very high values given in (h).

(j) All values were corrected for percent recovery; mean, standard deviation, and range exclude 2 very high values of 158 and $272 \mathrm{ppb}$ in batches produced on $2 / 23 / 81$ and $4 / 27 / 81$.

(k) All values were corrected for percent recovery; mean, standard deviation, and range include the very high values given in (j).

(i) $\mathrm{BHC}$ is hexachiorocyclohexane or benzene hexachloride.

$(m)$ The value of the one observation above the detection limit and the date it was obtained

(n) The detection limit increased from 0.01 to $0.05 \mathrm{ppm}$ after $5 / 81$.

(o) Six batches contained more than $0.05 \mathrm{ppm}$. 


\section{APPENDIX H}

EXPERIMENTAL DATA AUDIT OF THE SIXTY-ONE-WEEK INHALATION STUDIES OF 1,3-BUTADIENE 
The experimental data and tables of the draft Technical Report on the toxicology and carcinogenesis studies of 1,3-butadiene were examined for Good Laboratory Practices compliance and scientific procedures by the following persons: National Toxicology Program-Ms. C. Davies, Dr, C. Lingeman, Dr. M. Powers, Dr. B.A. Schwetz, Dr. C. Whitmire, and Dr. M. Wolfe; Experimental Pathology Laboratories, Inc.--Dr. W. Busey, Ms. H. Cook, and Dr. M. Hamlin; Tracor Jitco, Inc.--Ms. P. Errico and Ms. K. Rascigno.

The report of the audit of the 1,3-butadiene studies and the response to the National Toxicology Program audit report by Battelle Pacific Northwest Laboratories are on file in the National Toxicology Program. The main discrepancies or problems and their resolution were as follows:

1. Individual animal identification: A number of mice lost their eartags during the study $(35 / 300)$. Missing eartags were replaced at one time during the last month of the 61 -week studies. Mice were housed in individual cages inside the chambers continuously throughout the studies. In addition to eartags, animal identification was maintained by an animal/cage map. During the course of the studies, five mice were noted to have escaped from the chamber to the room floor. Two other chemicals (epoxybutane and ethylene oxide) were under test in the same room during part of the 1,3-butadiene studies. No mice from these other two studies were noted to be outside their chambers simultaneously with any of the five butadiene mice. Also, none of these five mice was identified as having missing eartags. Thus, it is not likely that mice were mixed up between dose levels of butadiene or that mice of the butadiene studies were mixed up with those of other chemicals under test at the same time. The wet tissue bags of 12 animals did not contain eartags ( 3 controls, 7 low exposure and 2 high exposure group mice). Ten of these died prior to the time the mice were retagged. Even if these mice were excluded from the studies, the final conclusions would be unaffected.

2. Potential exposure to other test chemicals: The daily exposure records mention leaks of butadiene and ethylene oxide into the room air in the room containing the chambers for these two chemicals and for epoxybutane. Further examination of the records by the laboratory personnel revealed that test animals in the chambers would not have been exposed to these chemicals even if they were in the room air because the leaks occurred when the chambers were closed and the intake air for chambers passed through filters to remove organic chemicals from the air.

3. Stress to certain animals: The male mice were without feed for 3 days during the 16 th week of the study. Four of these mice died in the following week. Also, the cage mesh sizes were such that some female mice sometimes got their head stuck in the openings of the cage walls. The eyes of these mice were often traumatized when the mice were freed. Although such stress is clearly undesirable, these animals are considered to be adequately representative of their respective groups.

4. Correspondence of clinical signs between observation periods: Individual animal observations made at any one time were not necessarily consistent with observations at later time periods. This may have been a function of loose terminology used to describe clinical observations, especially those of the eyes, or may have been due to animals' being in the wrong cages. Since mice are not likely to have been mixed up between groups, since separate chambers housed single dose groups, and since these observations during the studies are not a critical determinant of the final conclusions, this problem was not considered critical to the interpretations of the data.

5. Body weight data: Errors in the body weight data which were not adequately explained or dated were found. This was partially related to implementation of a new semi-automatic weighing system during the study. Although there were inconsistencies with GLP's, this problem was considered not to weaken the conclusions made in these studies. 
These findings and comments are based on the NTP audit and information obtained from Battelle Pacific Northwest Laboratory personnel. Any discrepancies that may have significantly influenced the final interpretation of these inhalation studies on male and female $\mathrm{B} 6 \mathrm{C}_{3} \mathrm{~F}_{1}$ mice were resolved. Minor problems not mentioned here which were not considered to affect the outcome of the study were not necessarily pursued to final resolution but are identified in the NTP audit report. In conclusion, the data examined in this audit are considered adequate to meet the objectives of these studies. 